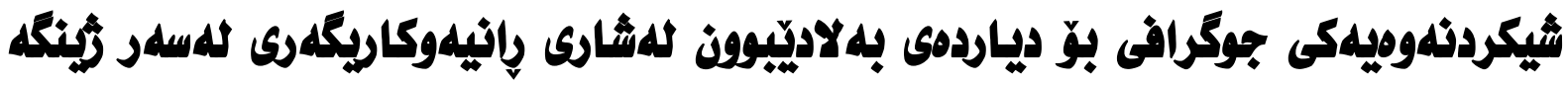

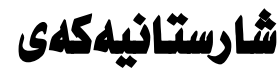

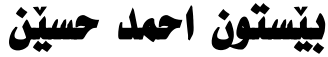

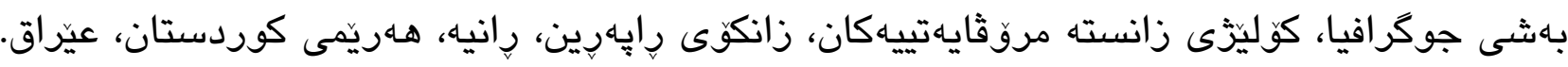

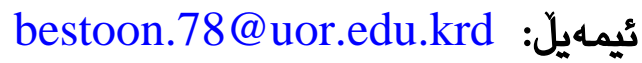

\section{بوخته:}

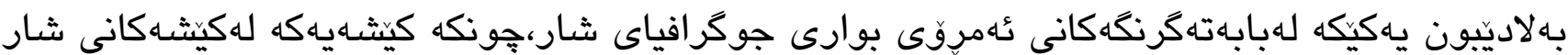

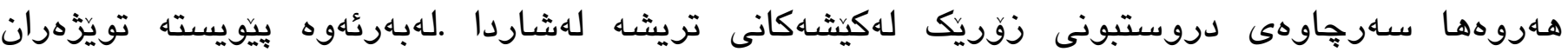

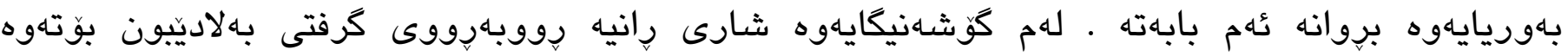

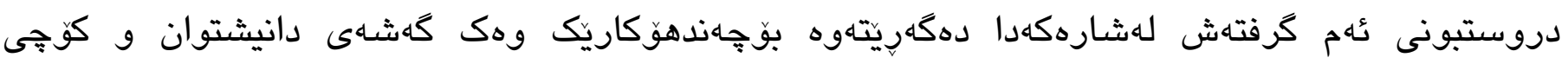

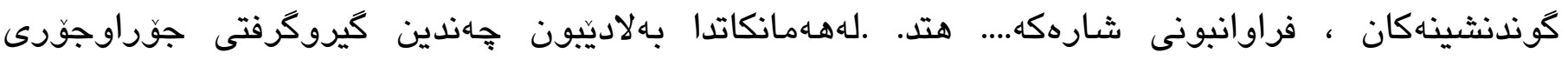

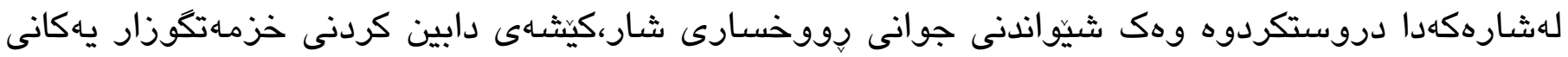

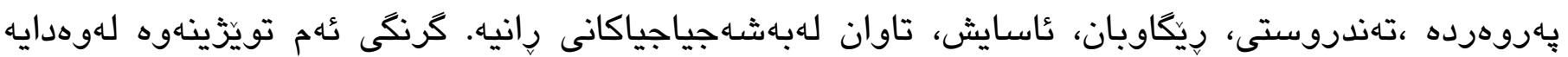

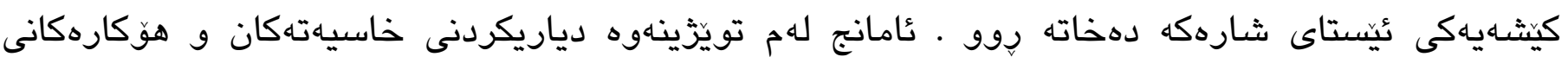

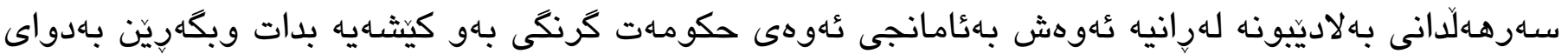

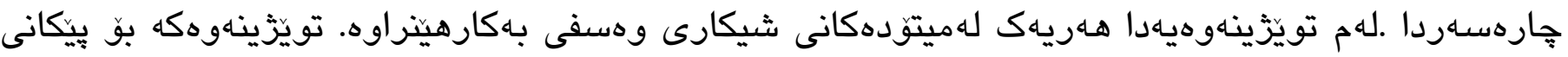

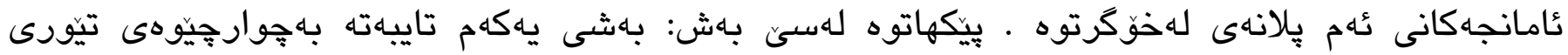

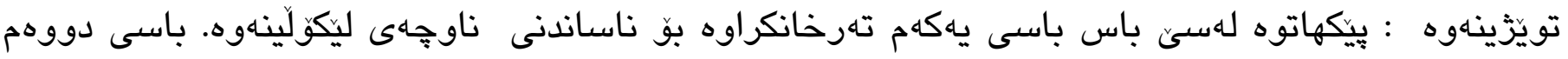

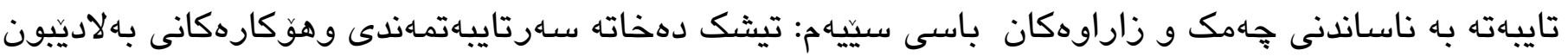

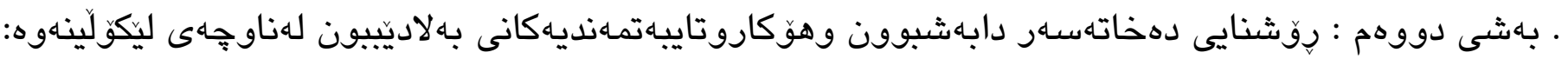

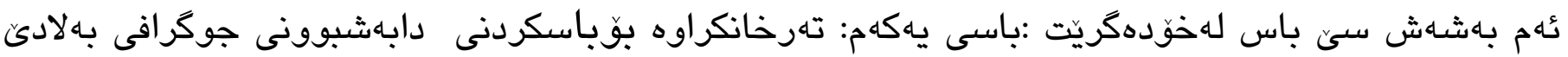

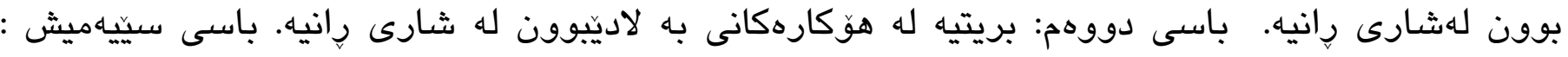

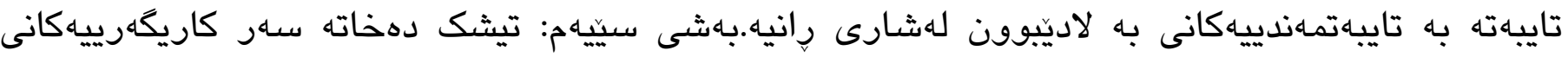

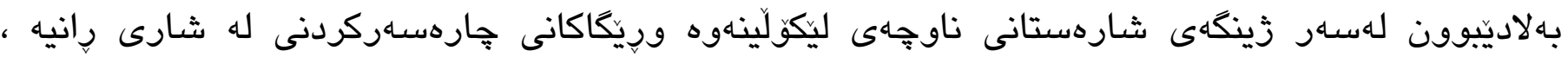

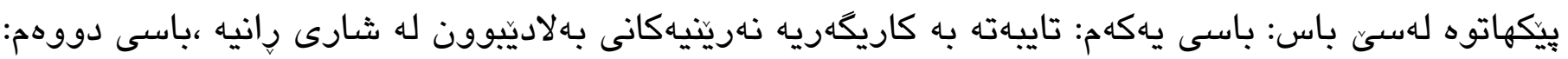

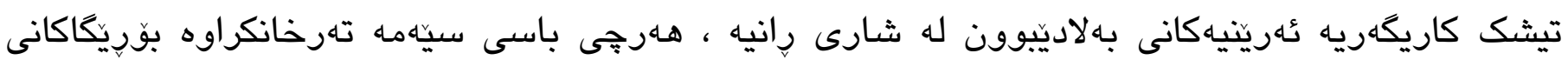

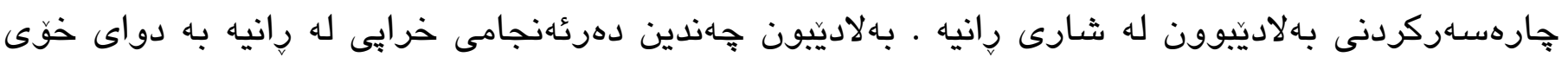

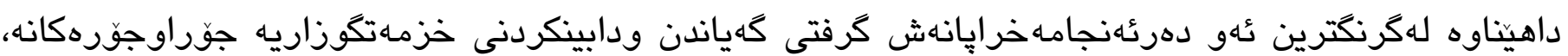

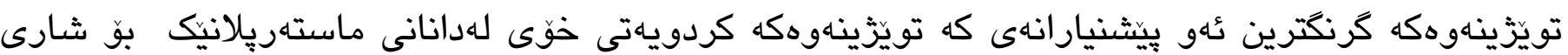

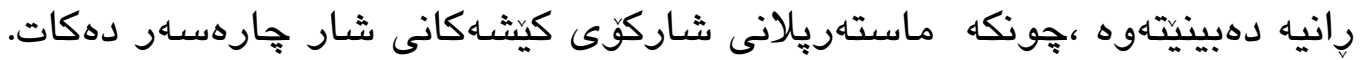

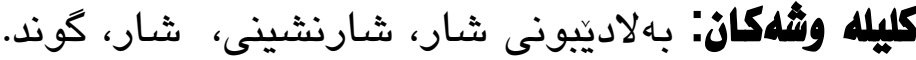




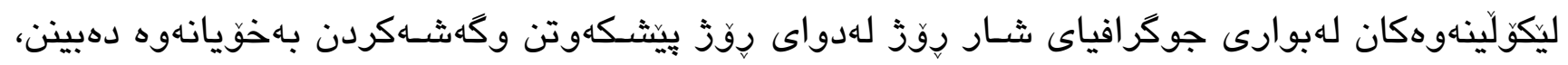

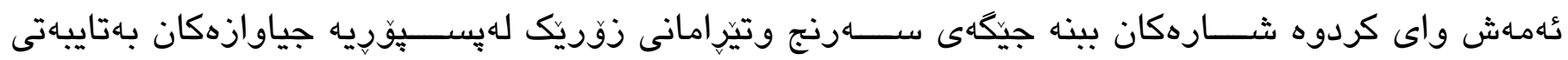

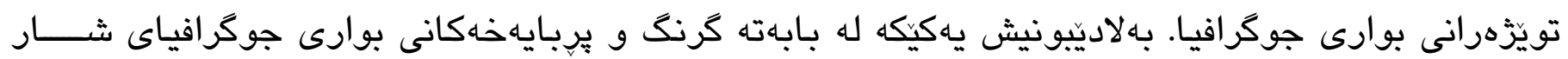

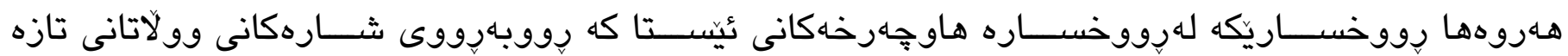

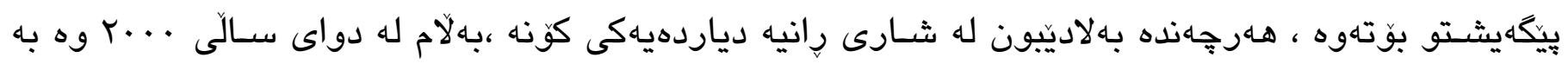

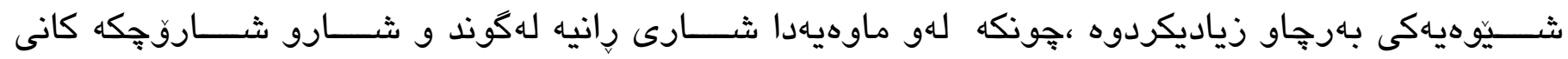

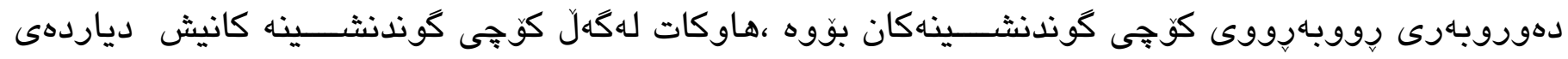

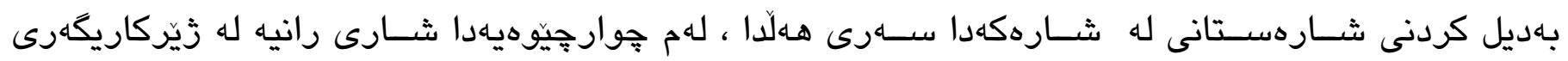

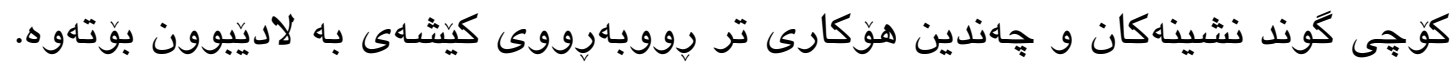

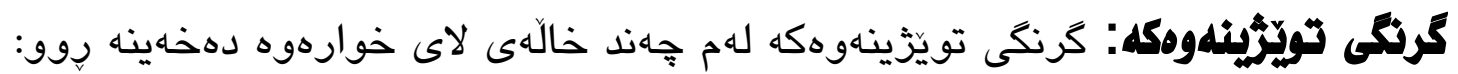

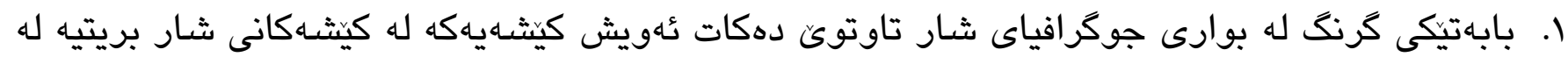

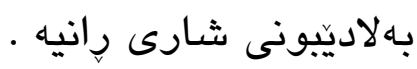

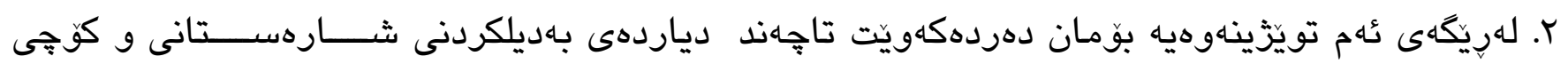

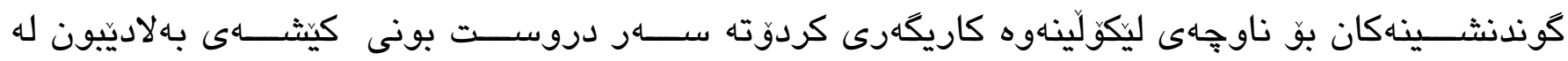

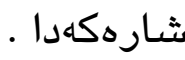

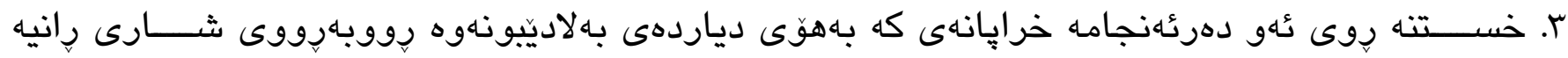

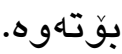

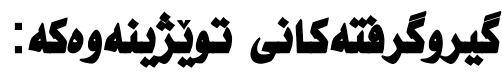

لـهاوهى نووسيندا، تويَّينهوهكه رِووبهرووى ئهم كيروكرفتانهى لاى خوارهوه بوّتهوه:

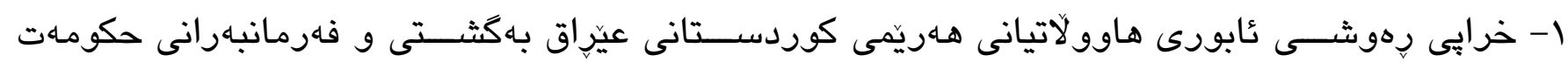

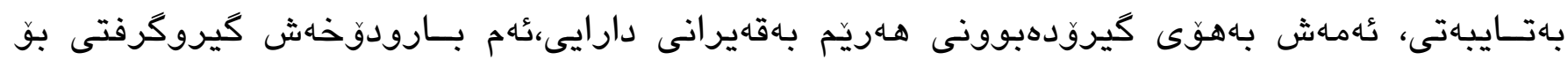

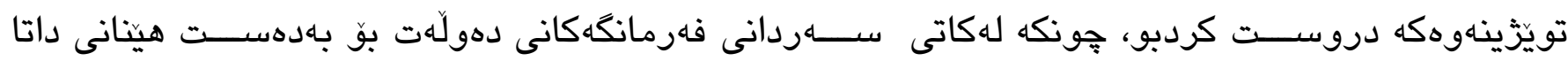

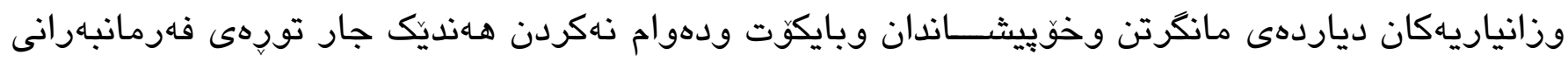

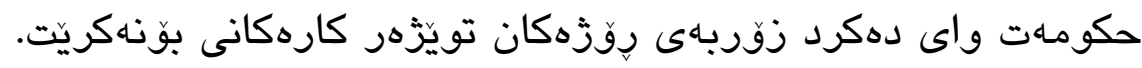

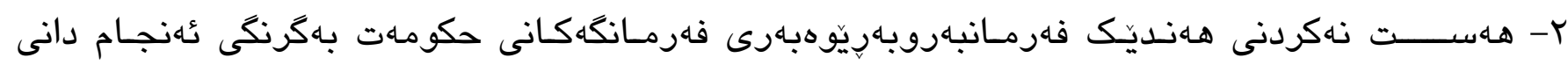
تويَّينهوه.

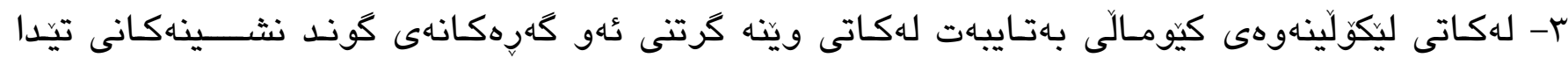

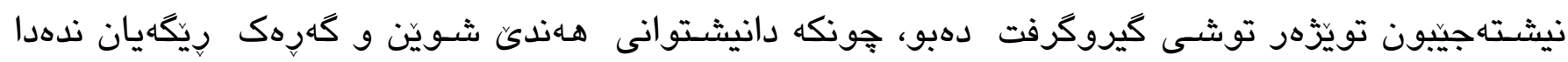

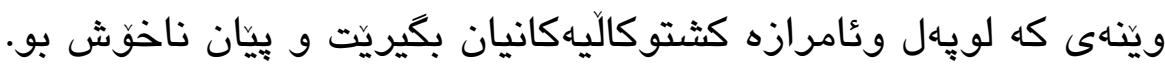


ئامانجهكانى ئهم تويَّينهوهيه بريتيه لهم خالآنهى لاى خوارهوه:

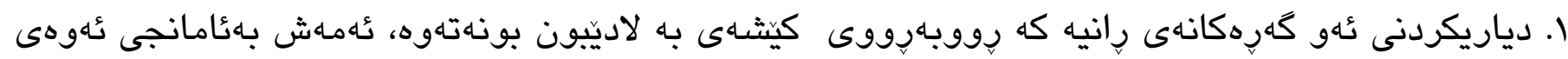

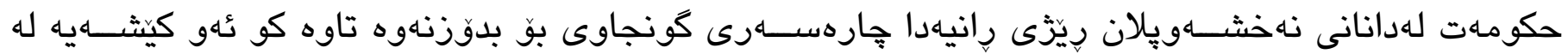
كايندهدا دووباره نه بيتهوه.

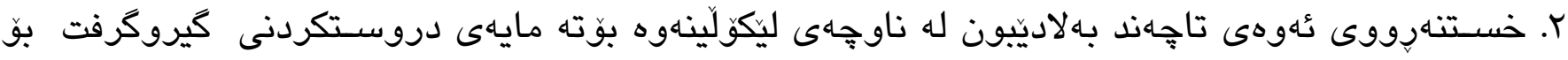

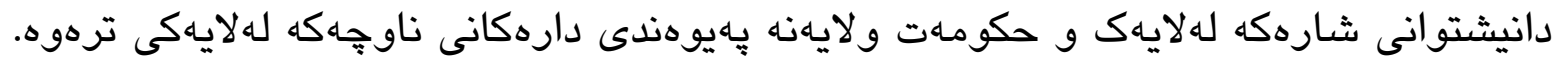

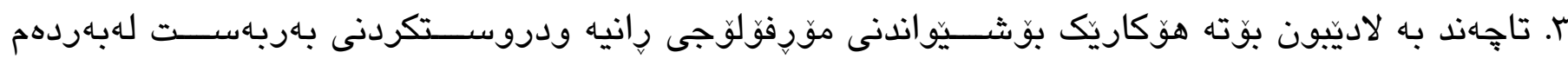

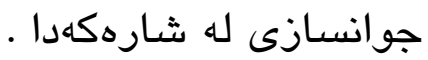

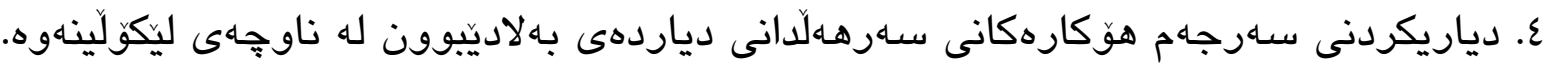

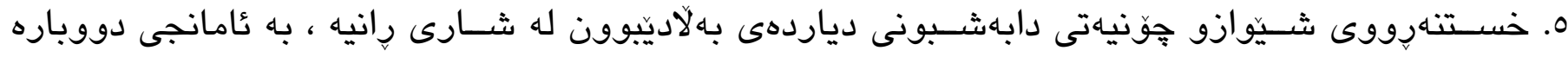

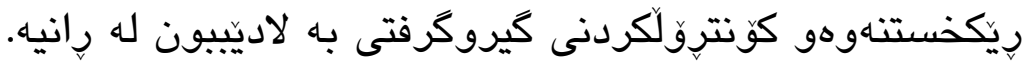

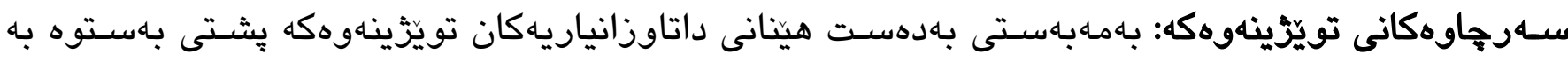

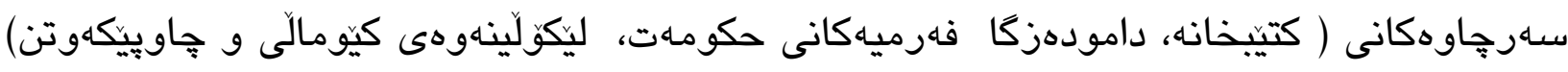

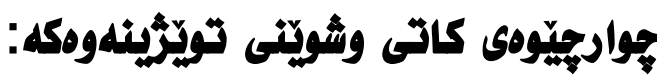

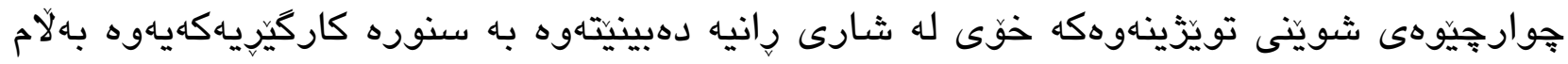

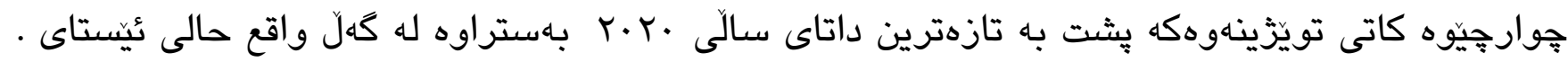

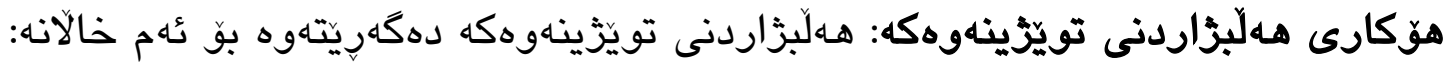

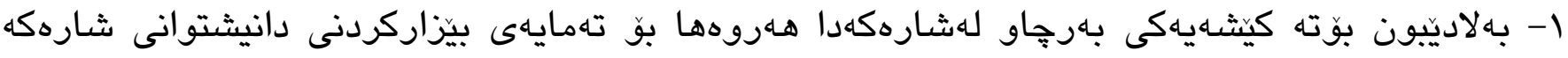

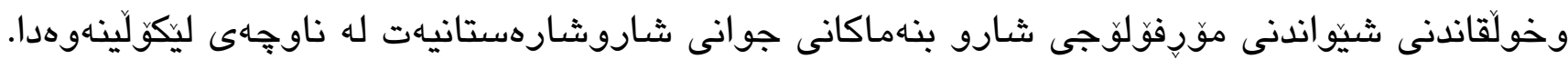

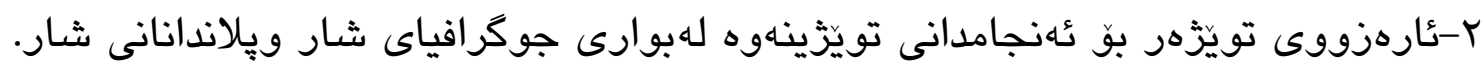

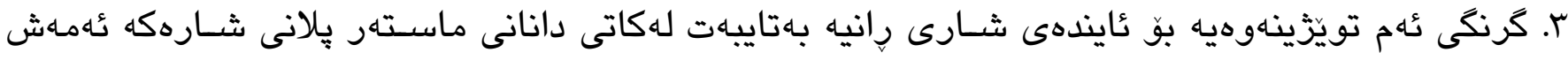

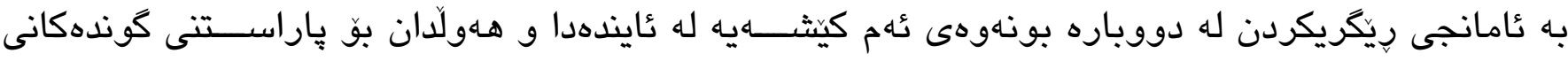

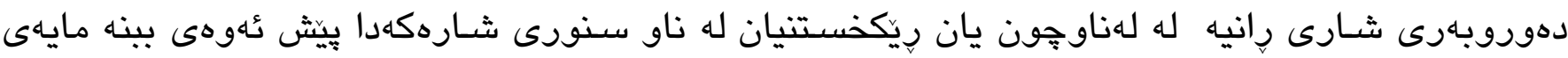

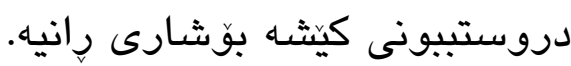

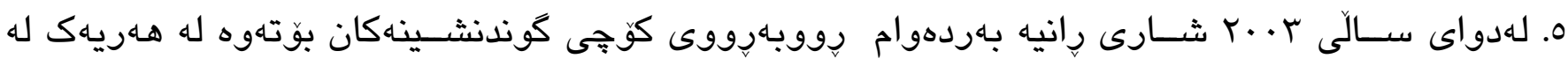

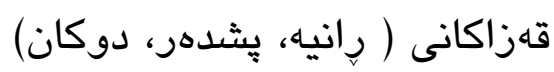




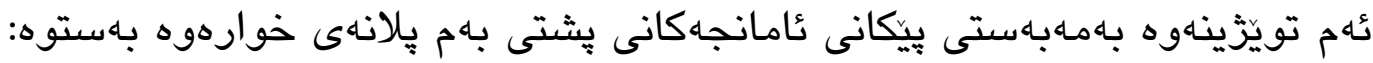

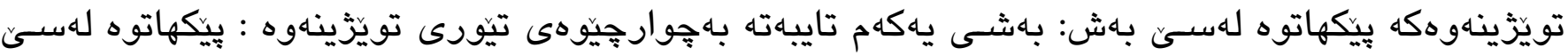

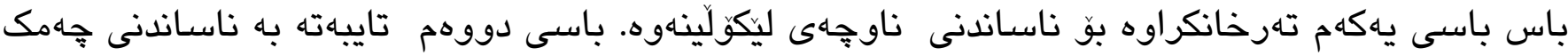

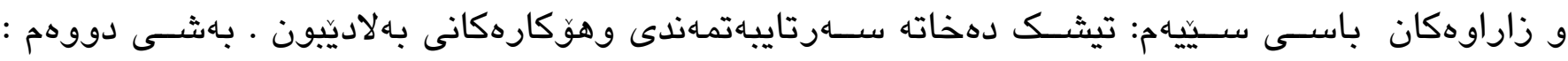

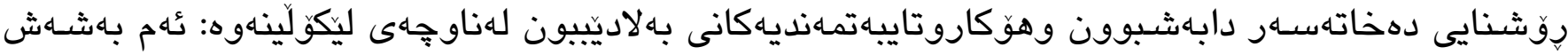

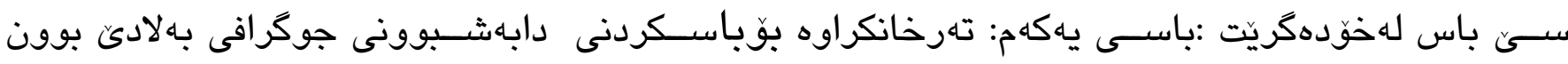

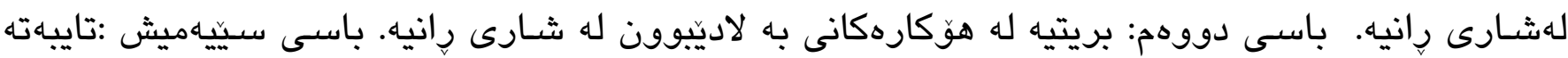

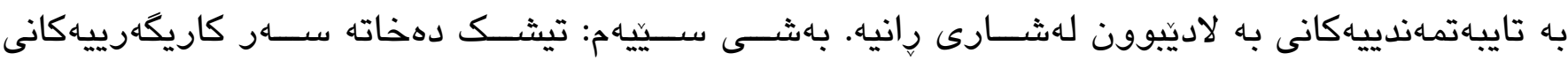

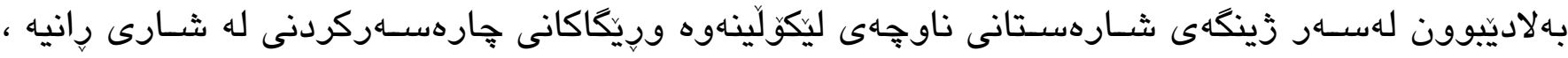

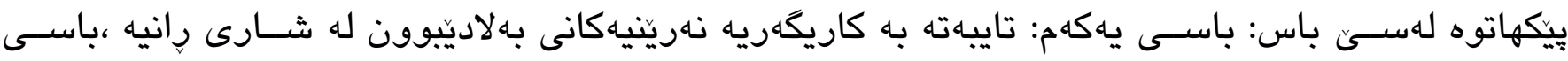

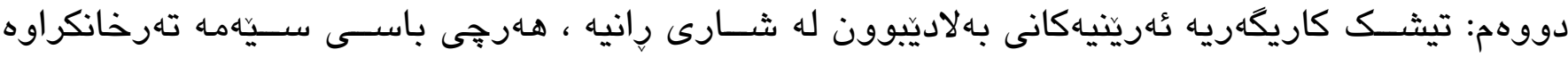

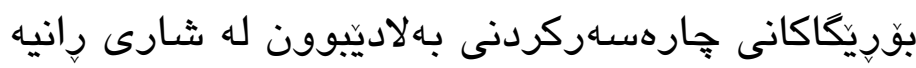

\section{ميتوّدى تويَّرئنهوهكه :}

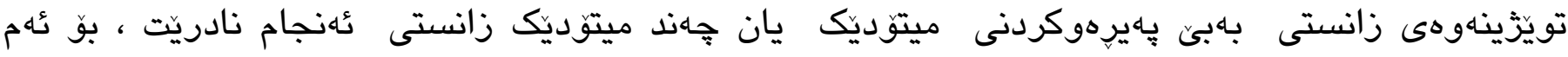

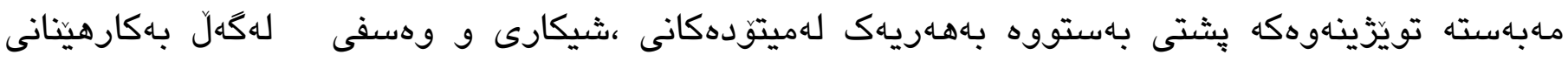

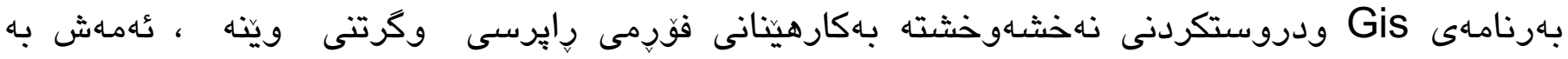

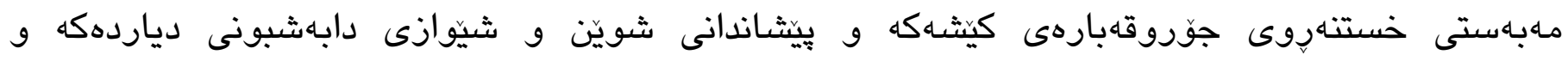

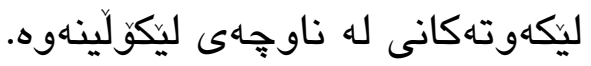

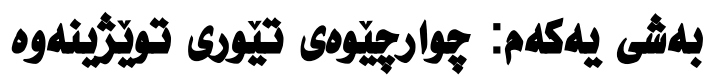

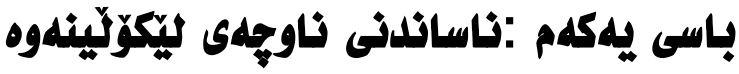

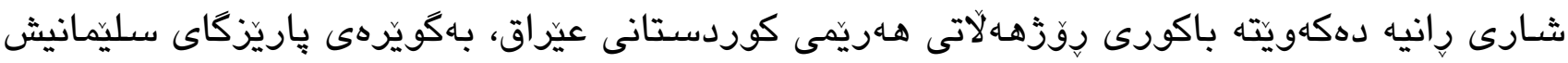

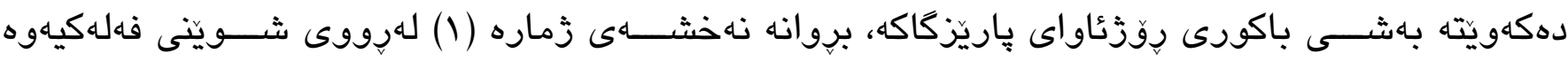

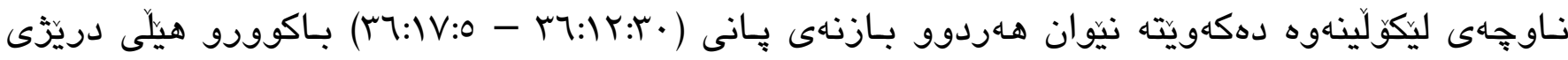

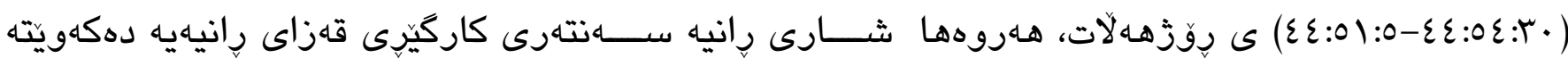

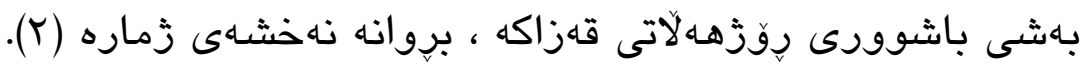

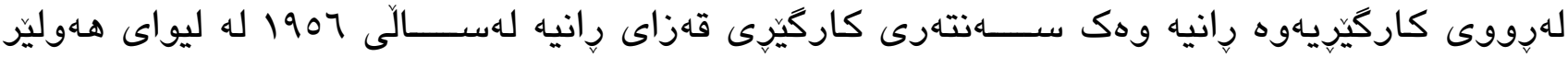

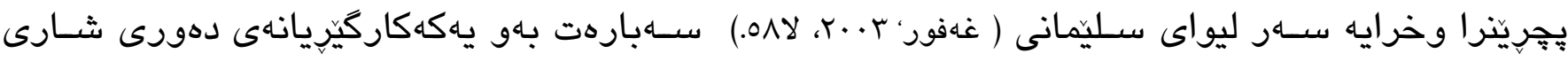

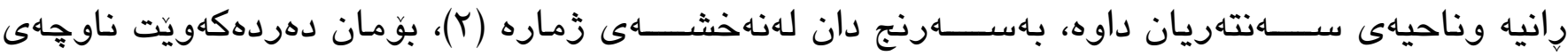




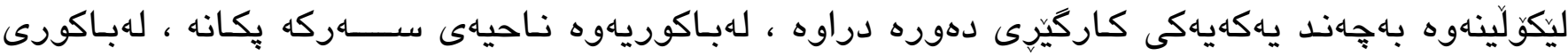

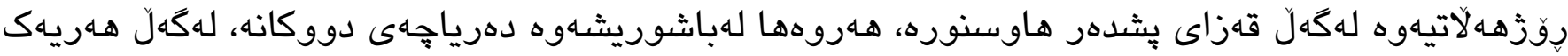

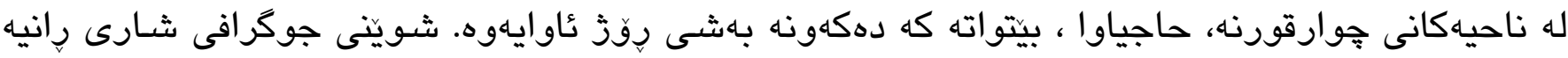

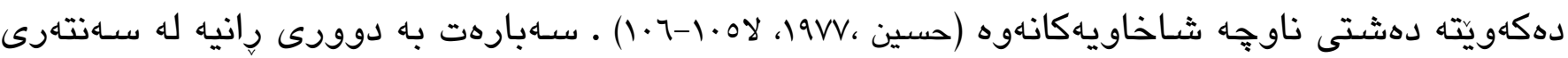

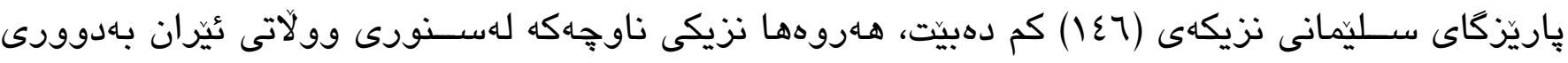

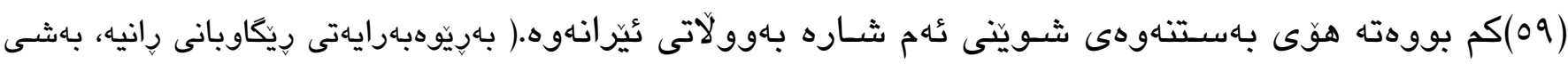

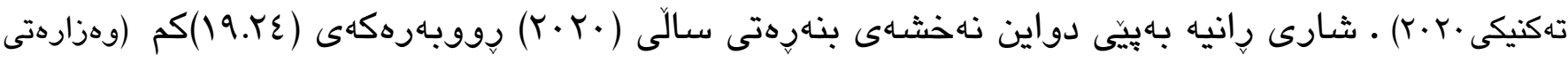

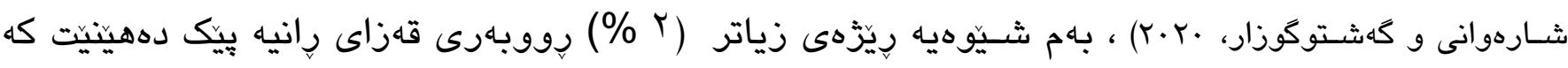

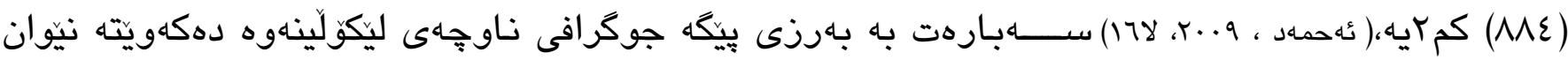

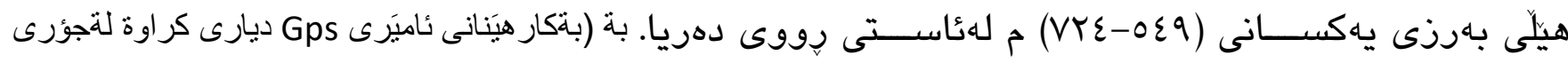

(Garmin rino 120.

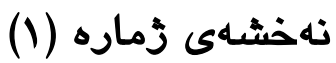

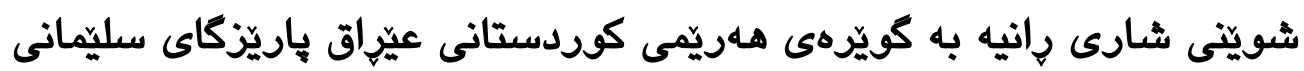

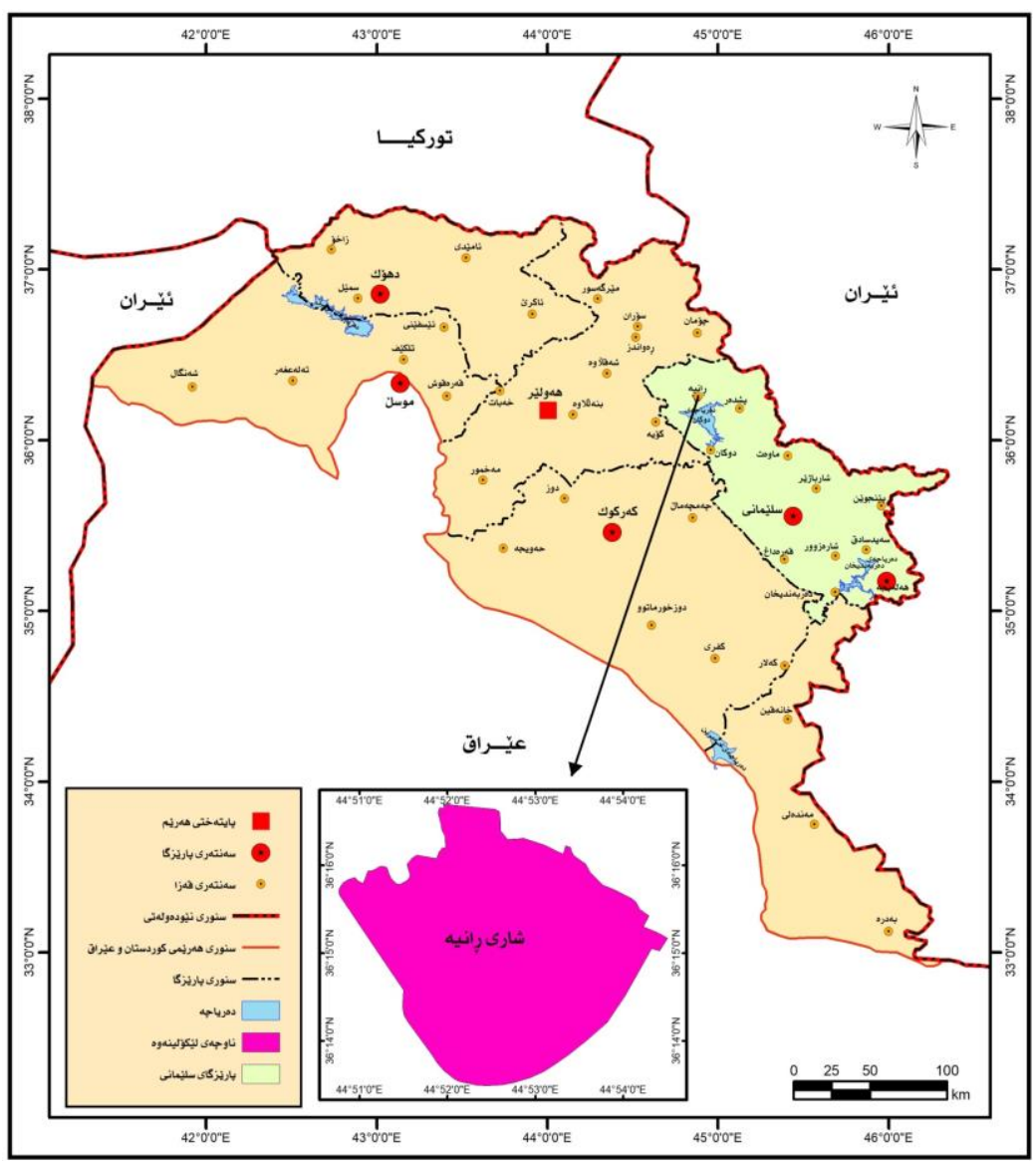

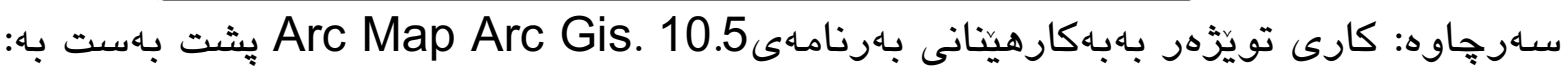

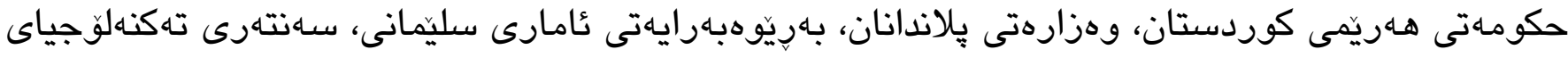

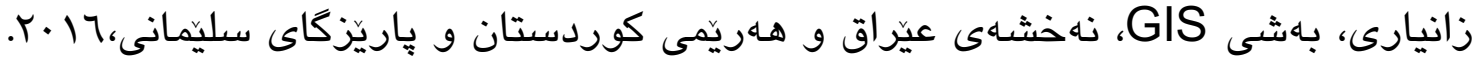




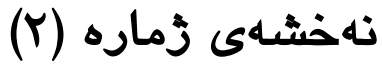

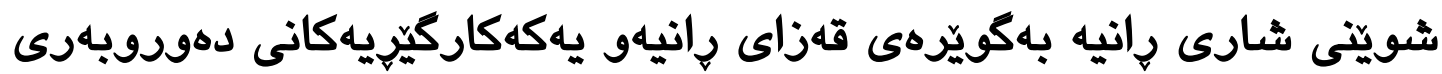

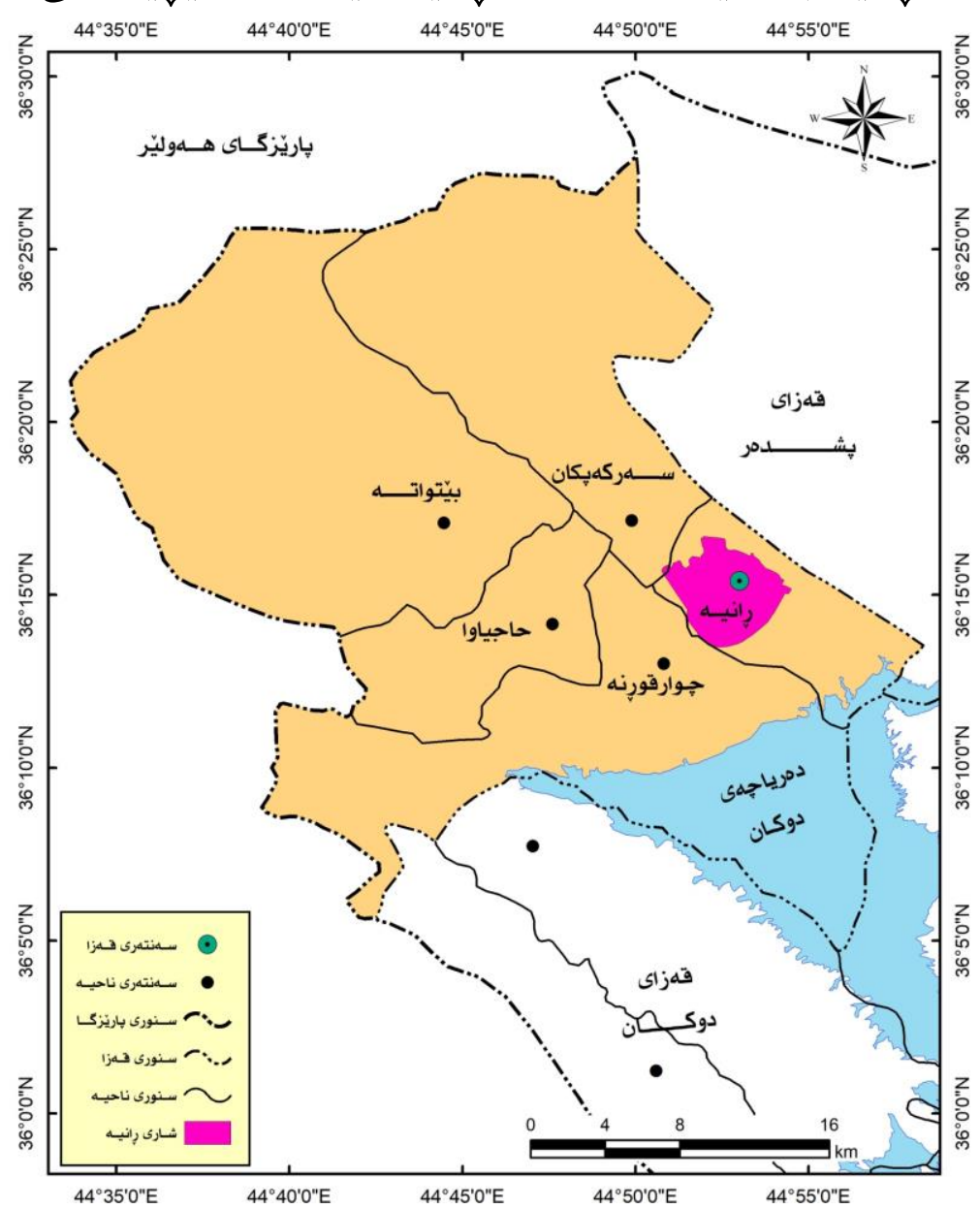

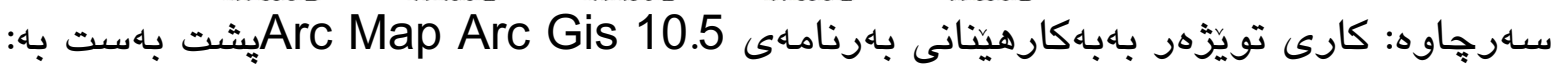

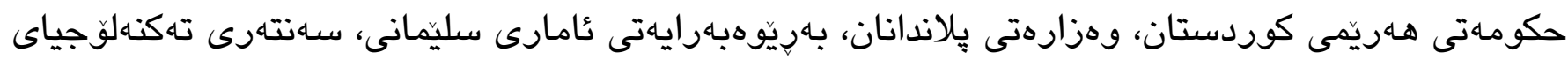

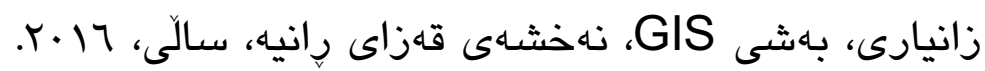

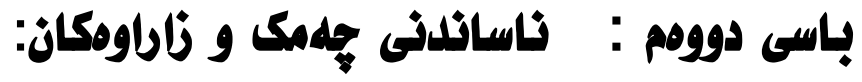

ilit

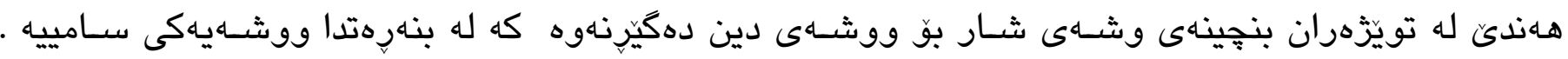

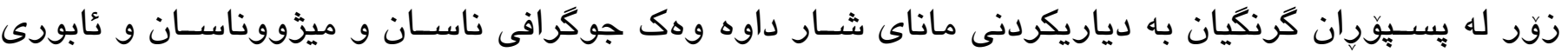

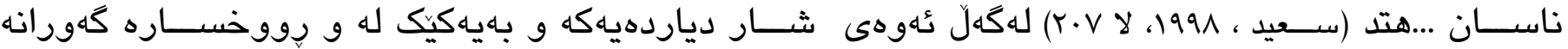

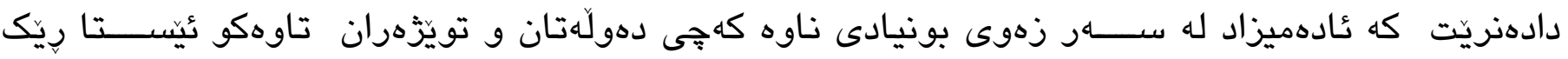

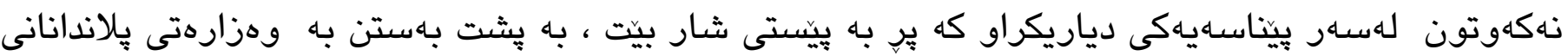

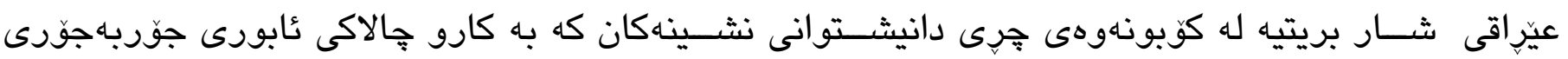

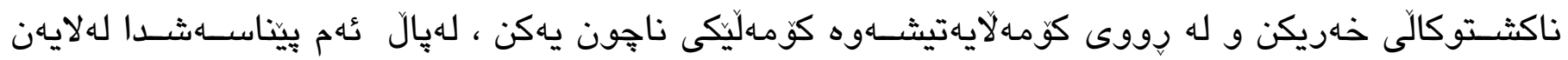

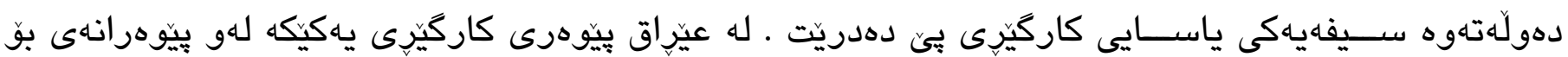

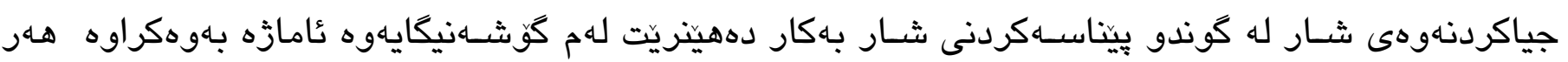




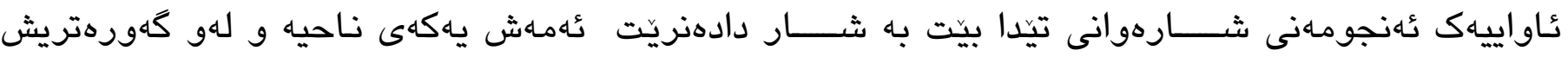

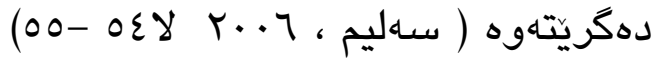

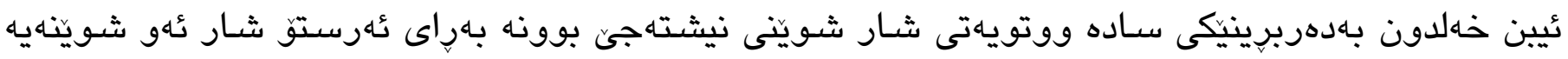

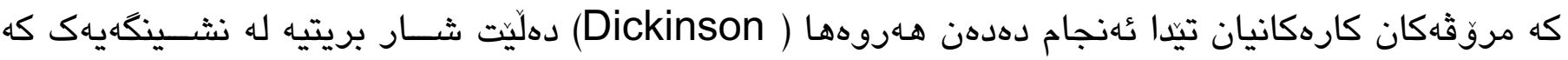

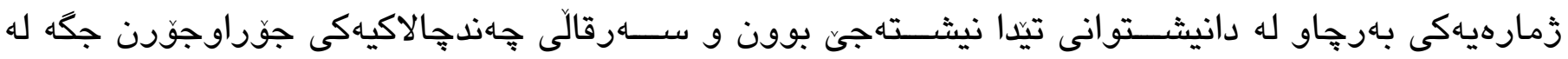

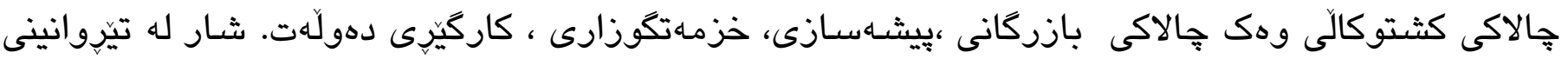

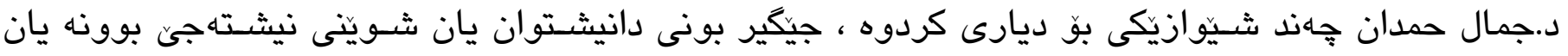

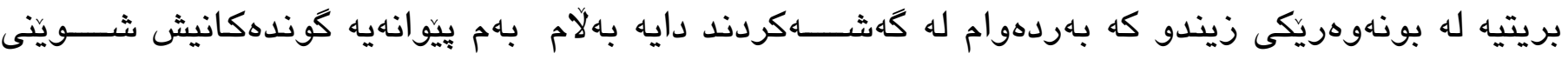

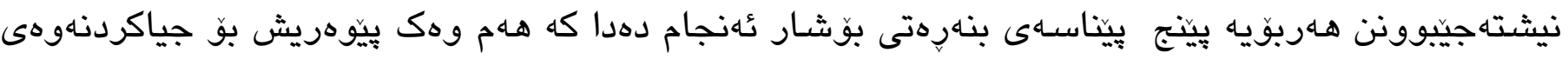

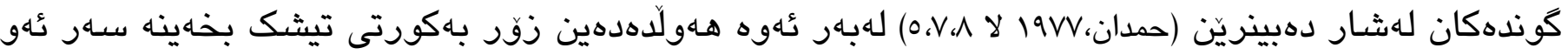

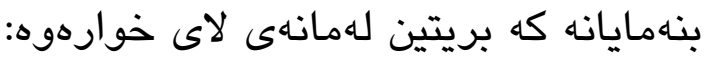

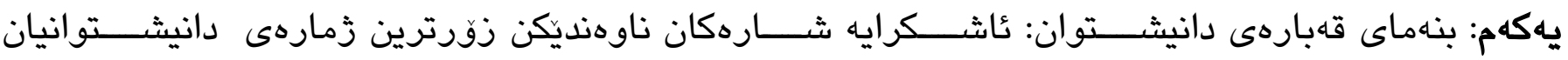

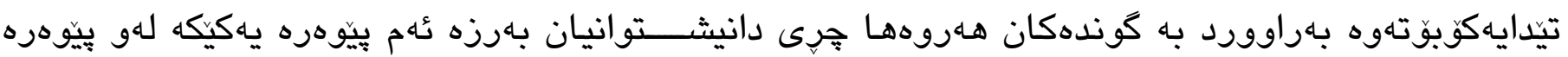

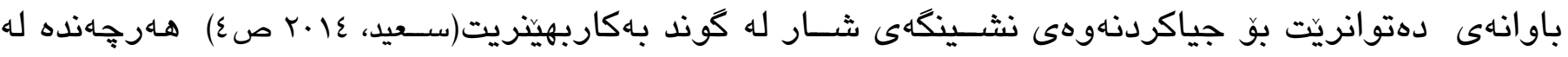

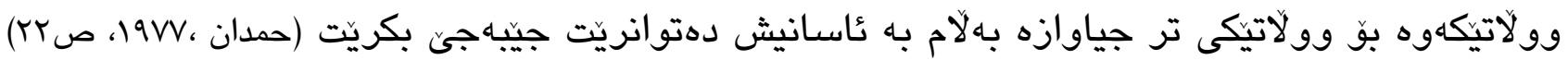

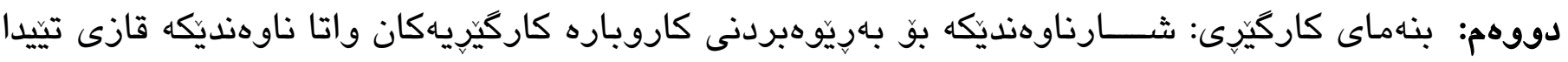

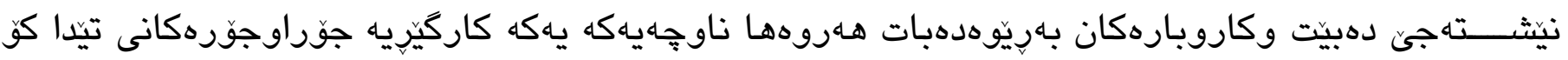

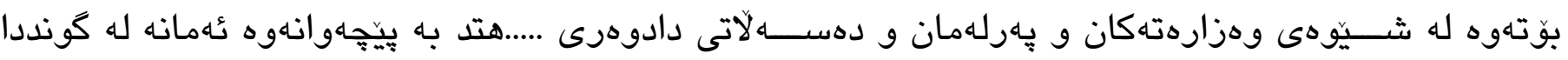

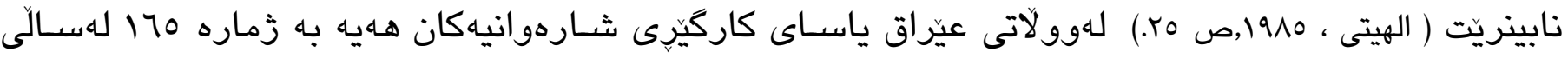

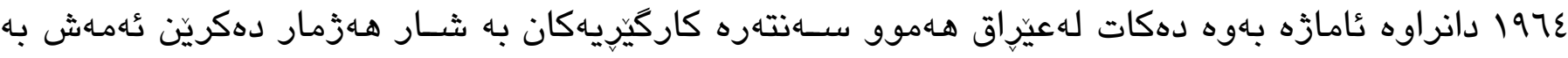

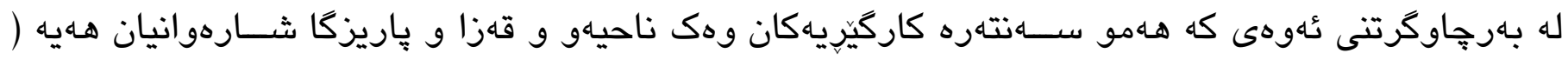

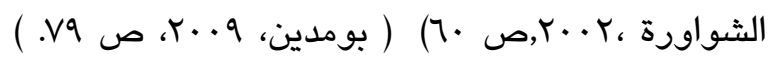

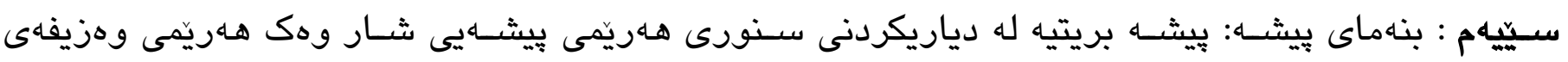

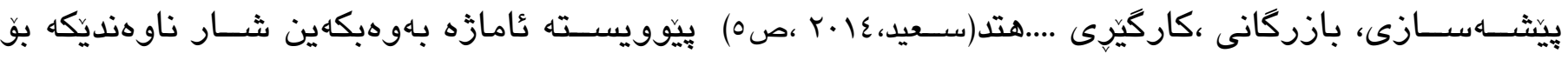

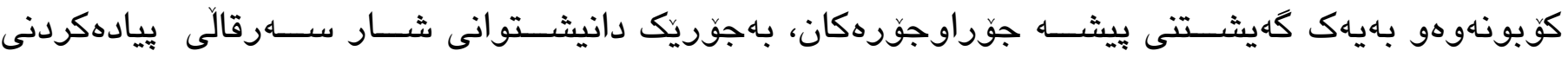

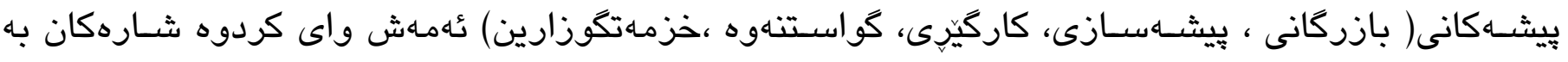

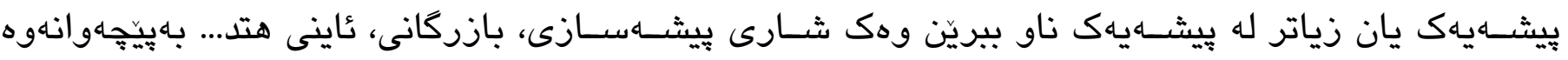

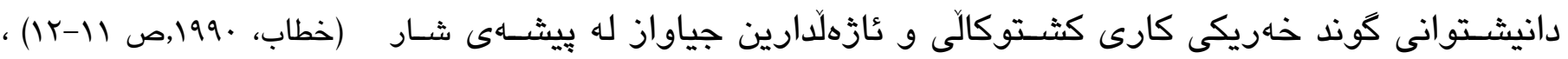

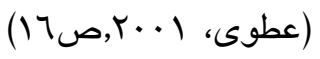

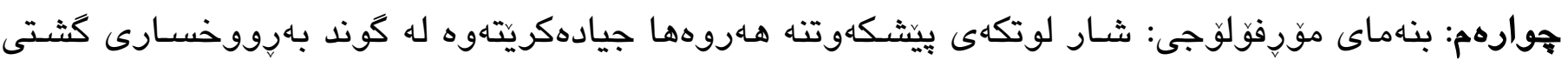

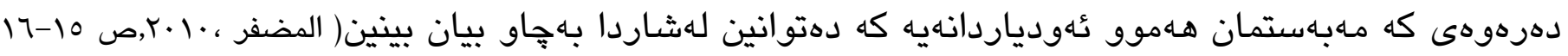

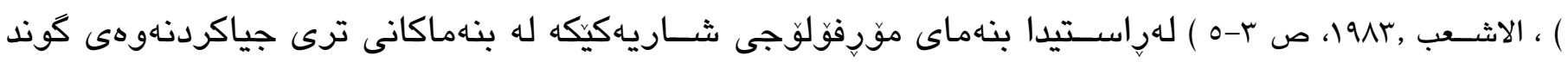

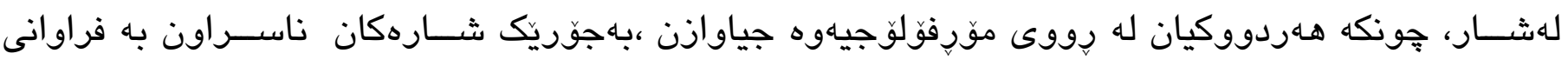

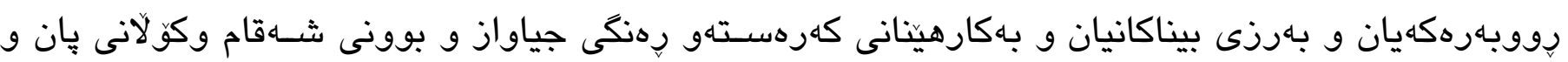

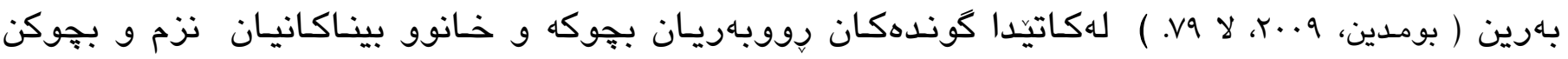




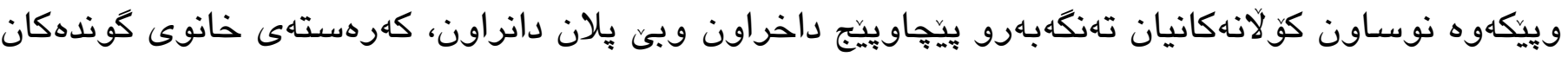

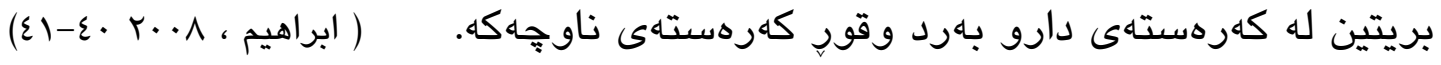

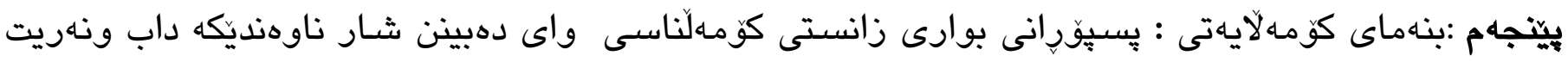

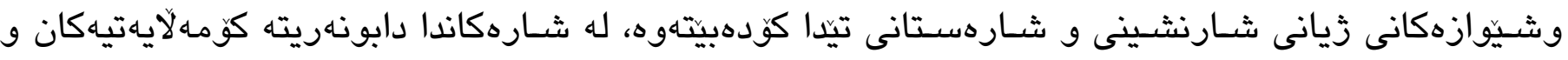

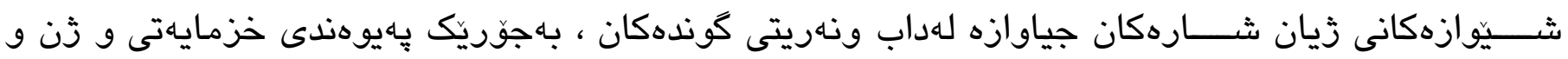

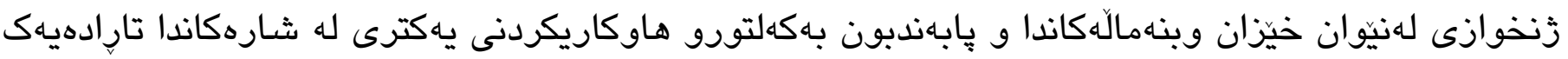

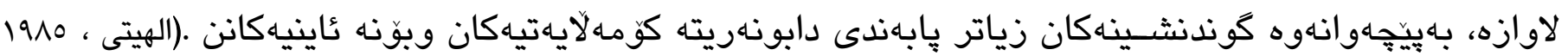

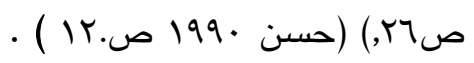

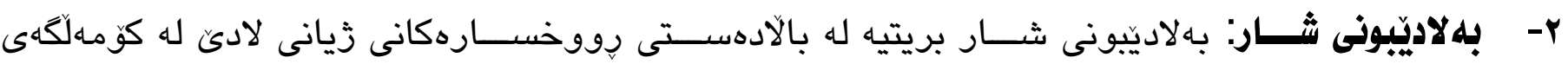

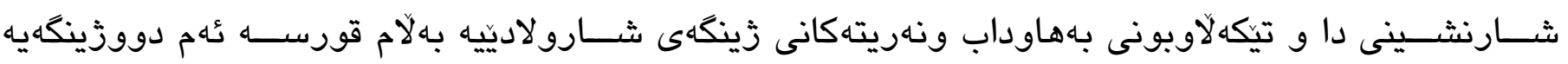

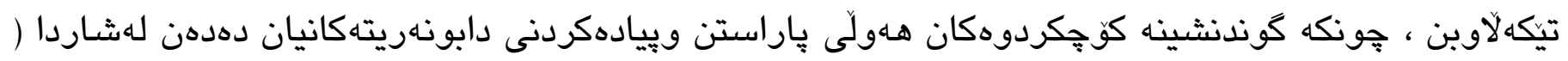

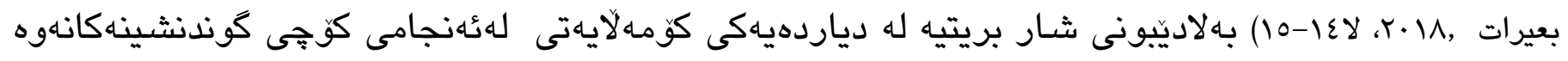

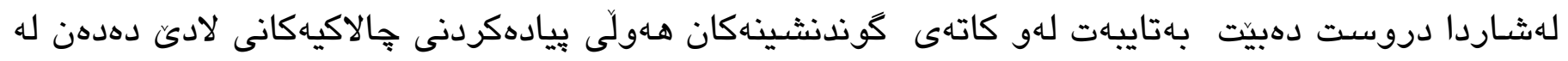

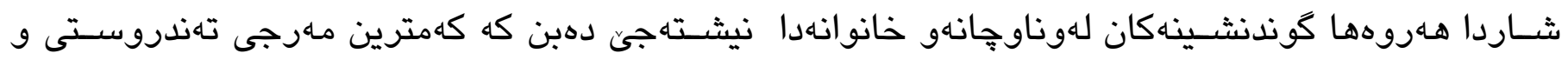

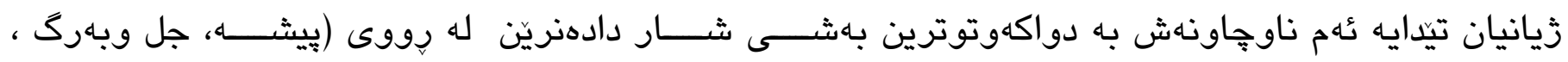

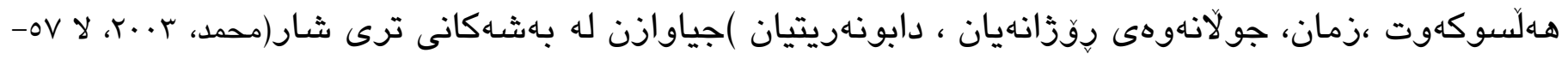

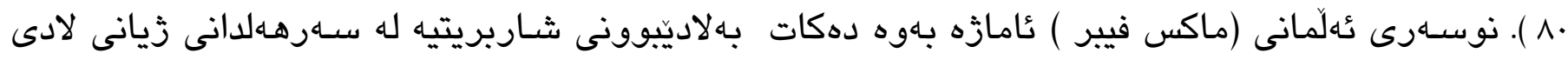

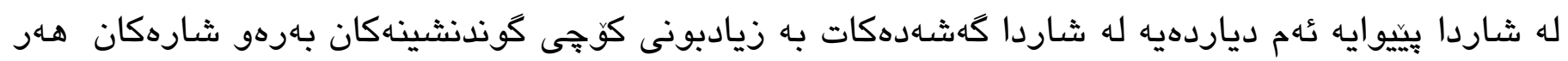

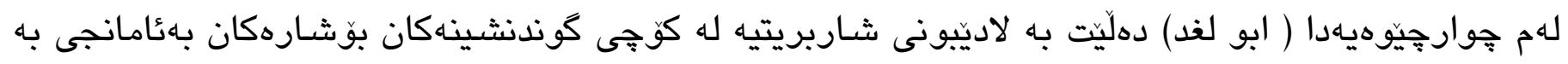

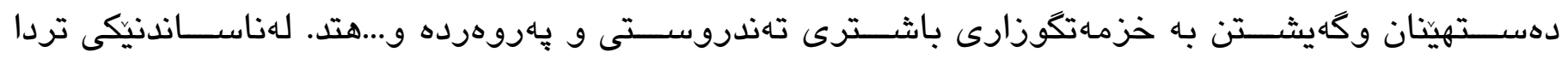

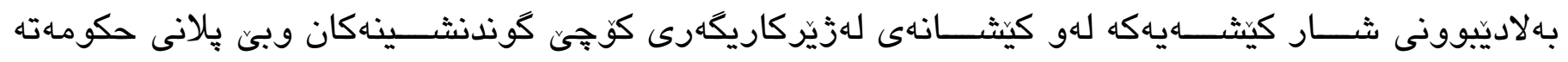

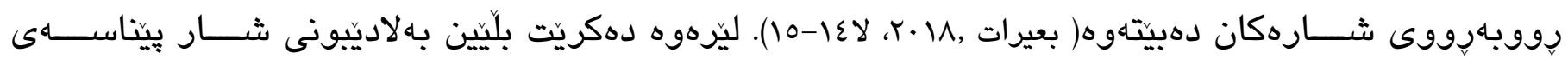

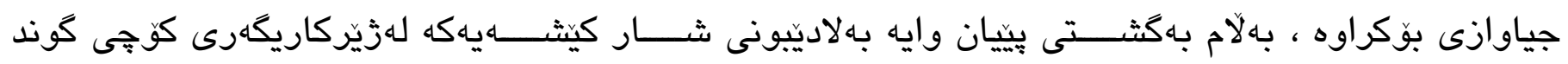

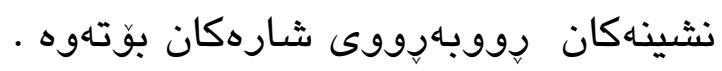

\section{r- شارنشينى:}

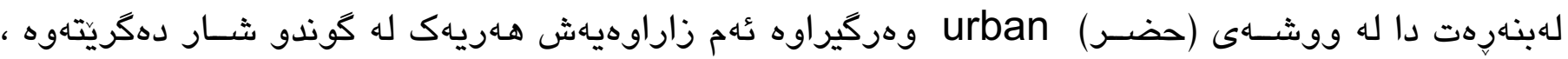

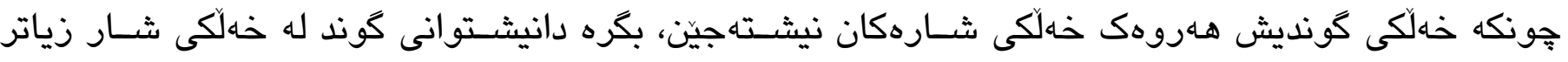

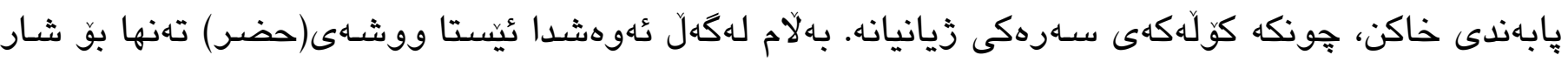

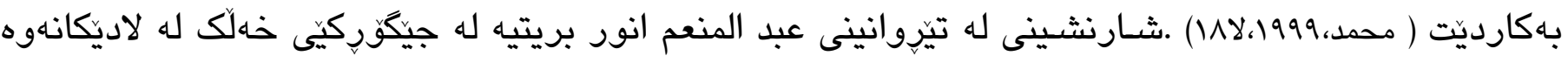

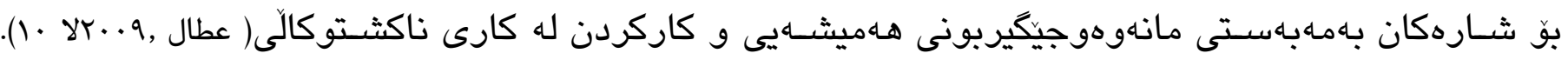

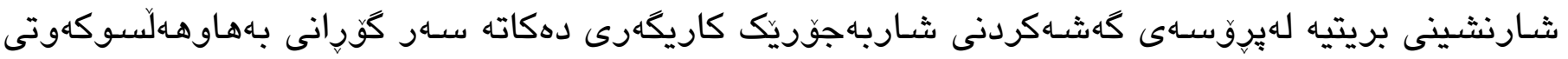

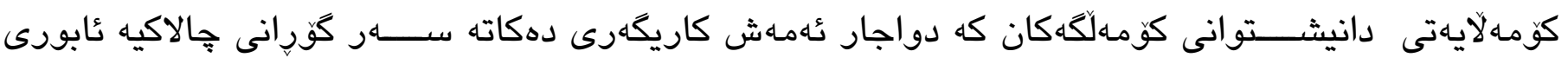

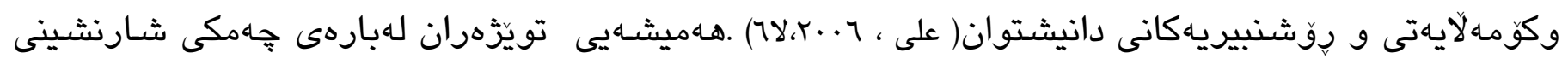




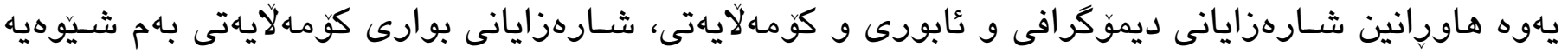

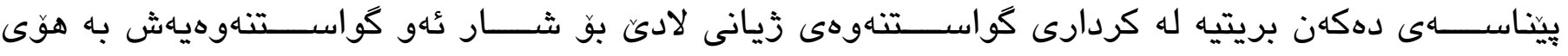

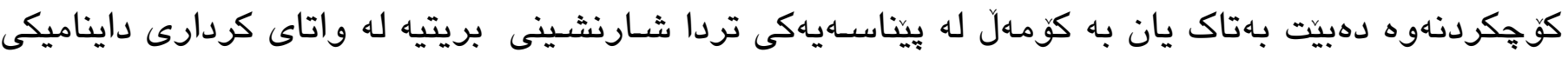

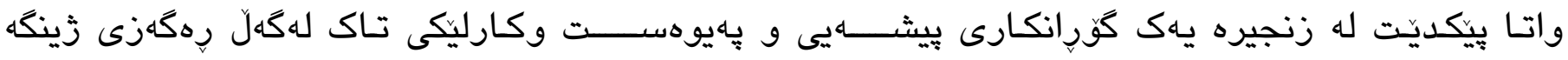

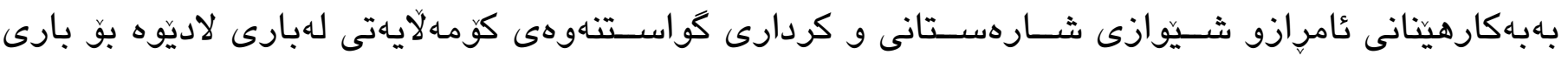

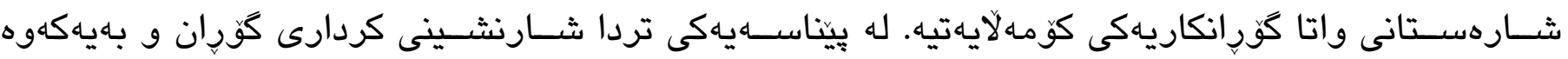

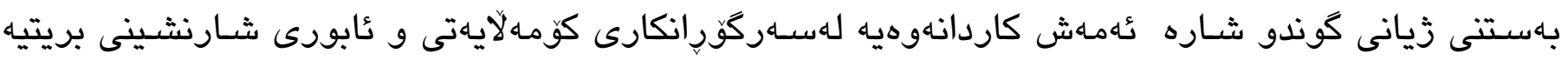

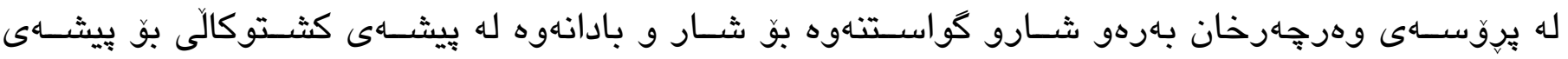

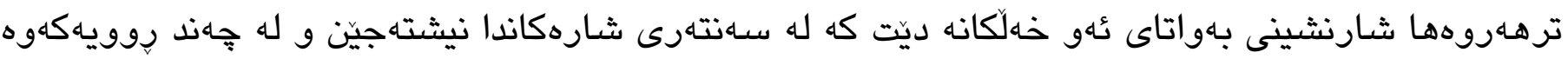

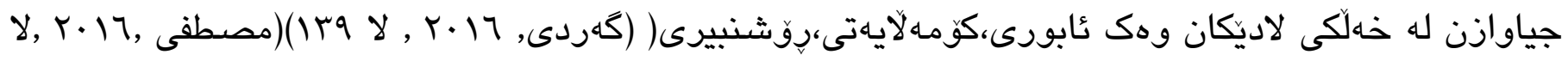

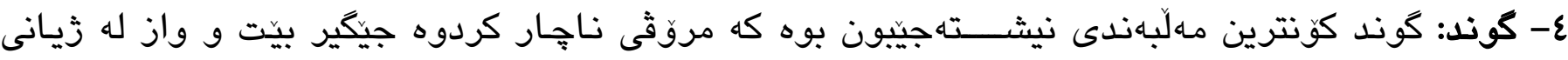

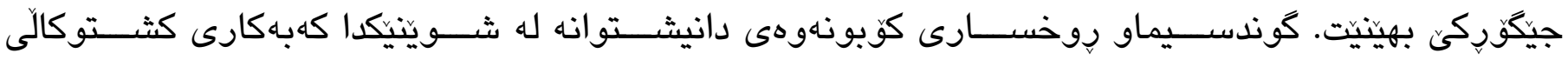

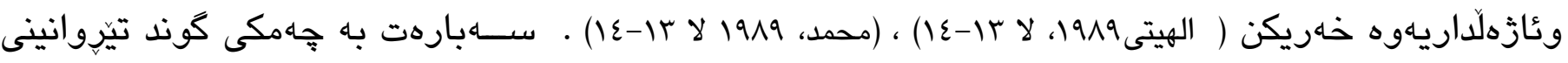

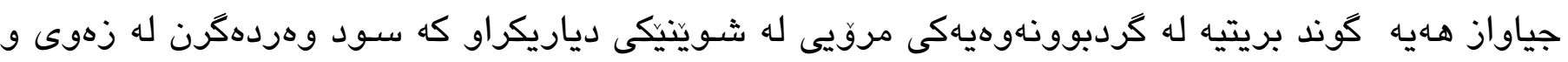

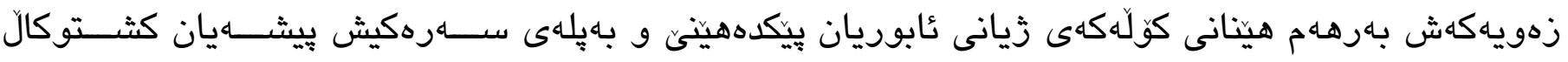

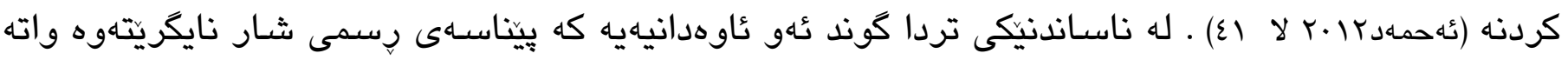

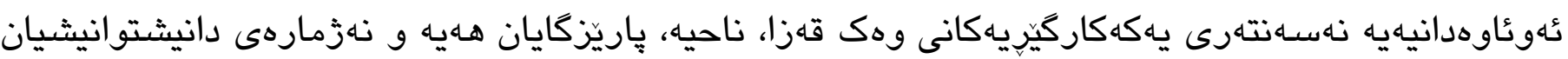

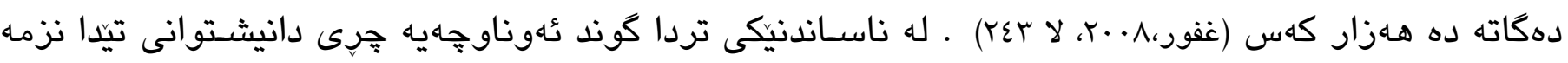

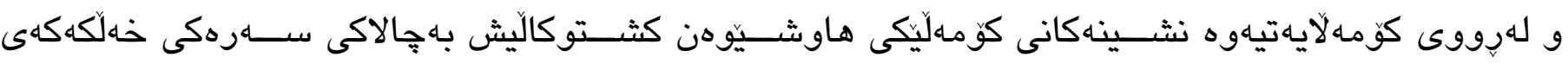

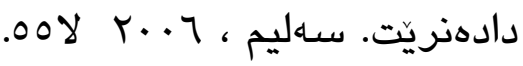

\section{باسى سيّيلهم : خاسيهتهكان وهوّكاروكانى بهلاديّبوذى شار

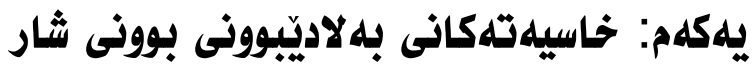

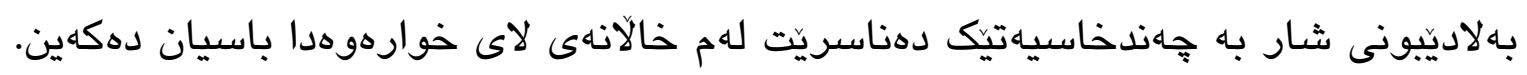

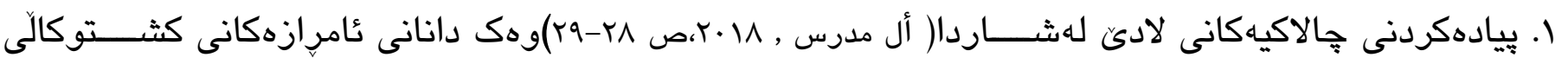

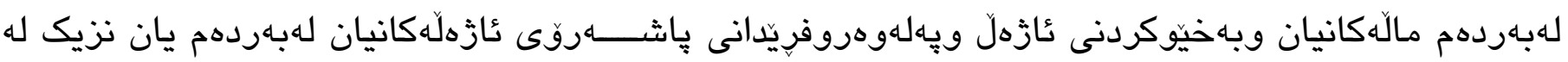

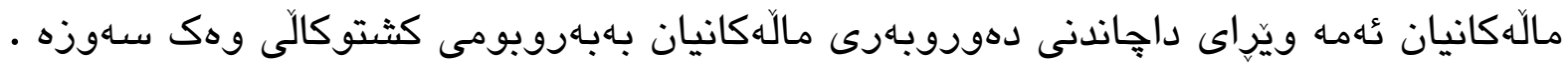

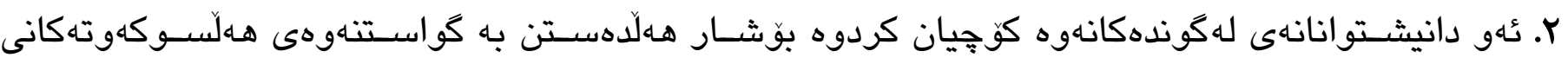

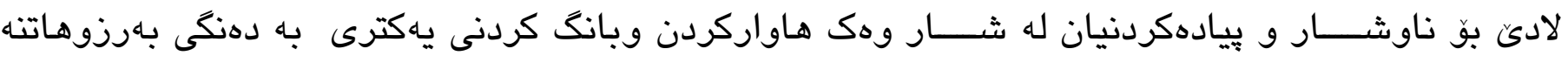

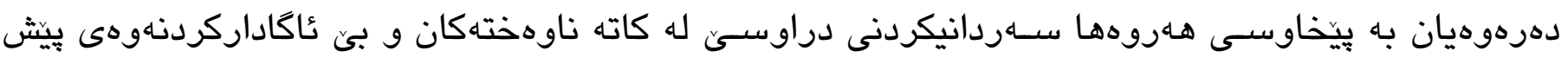

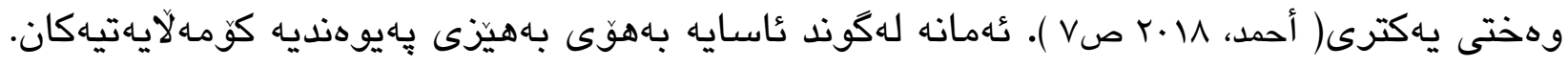

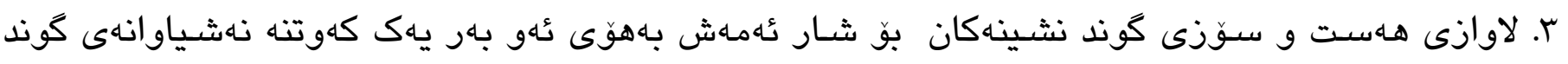

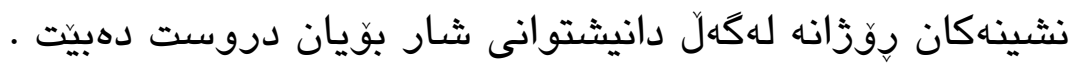




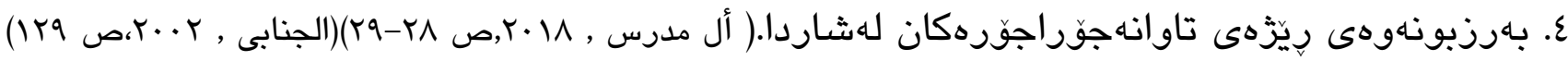

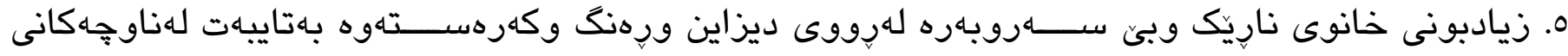

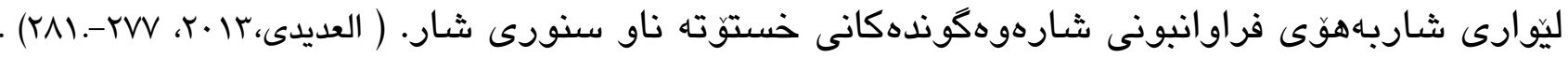

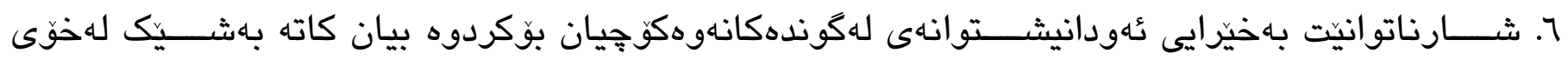

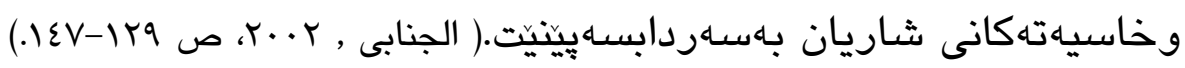

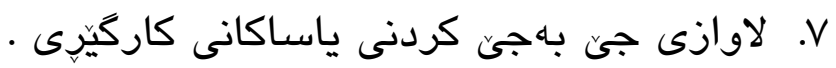

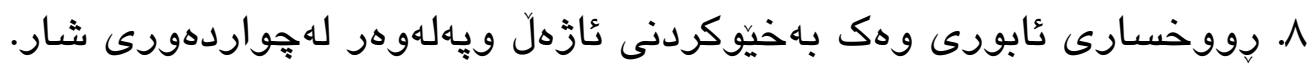

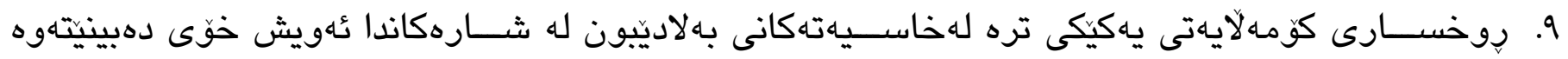

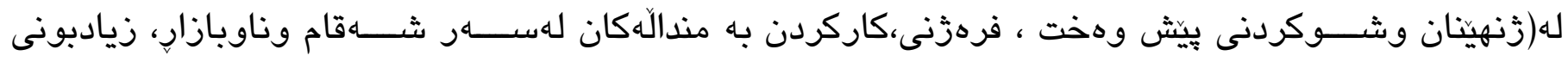

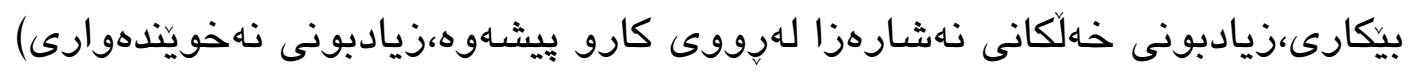

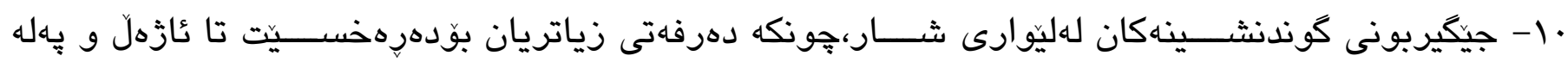

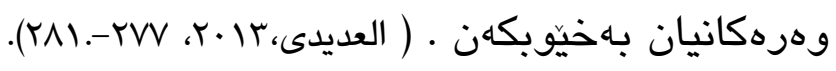

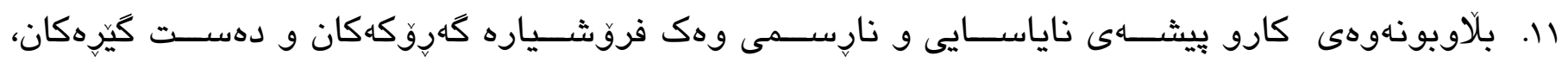

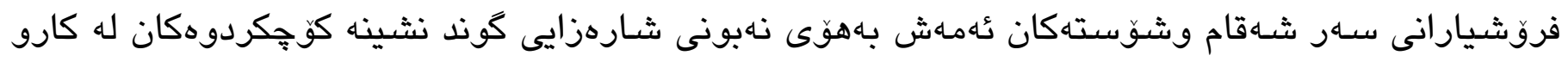

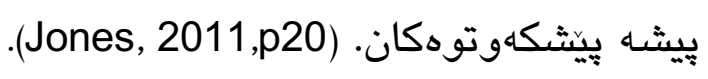

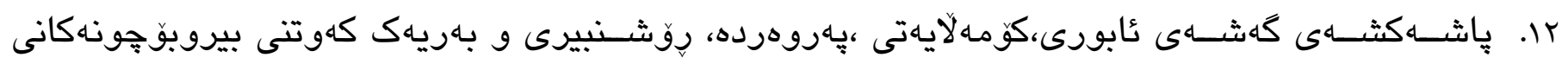
دانيشتوانى لادىخ وشار(

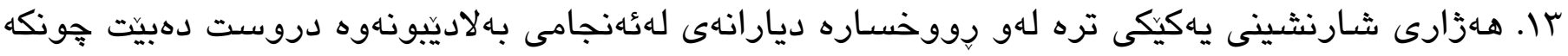

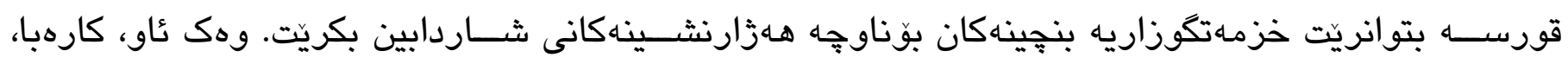

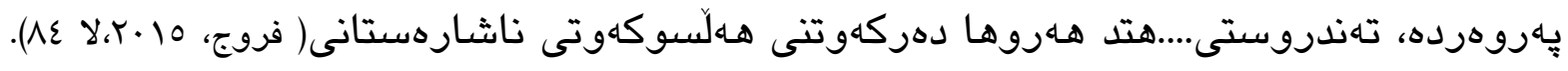

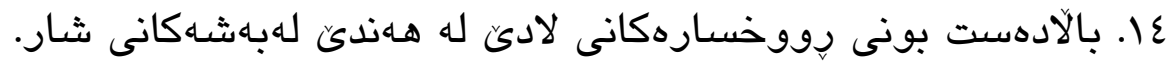

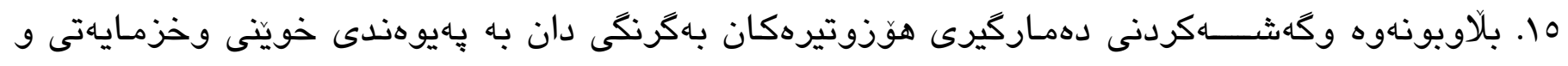

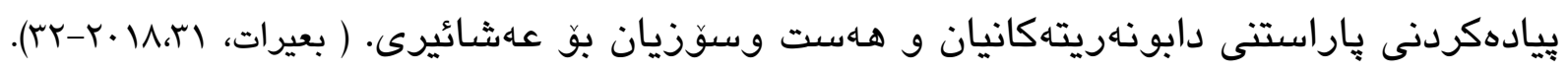

\section{دووهم: هوكارمكانى بهلاديبيوونى ثُار}

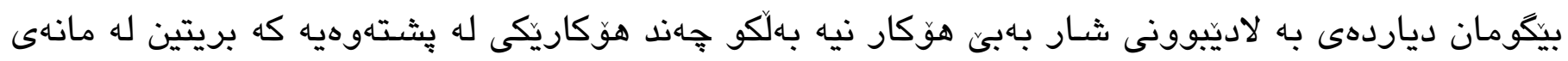
لاى خورهوه:

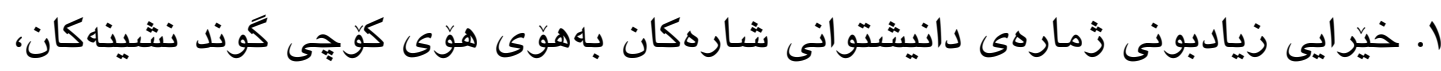

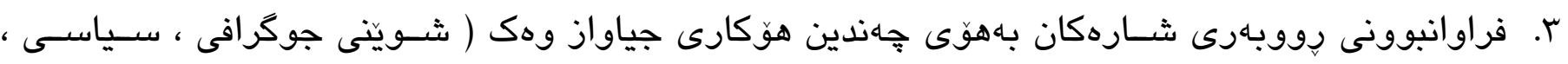

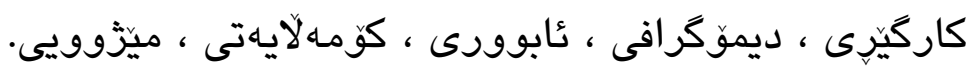

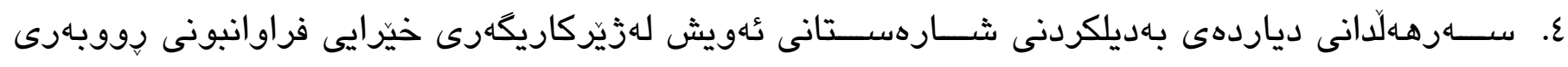

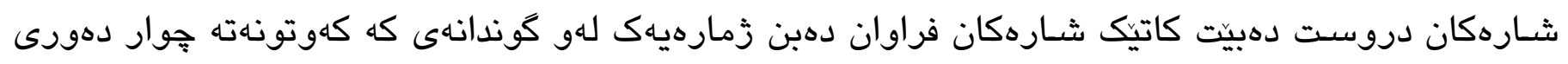

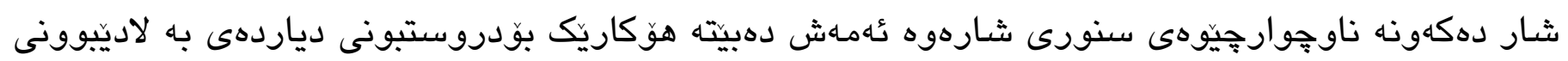

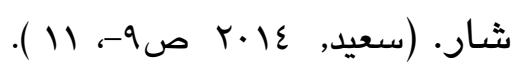




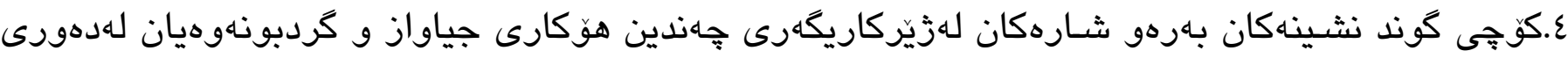

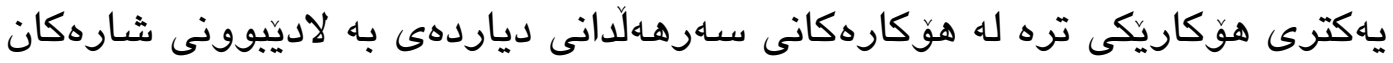

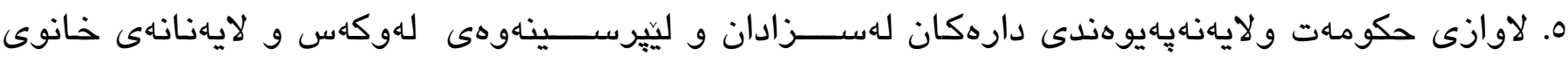

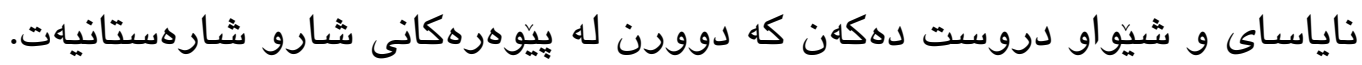

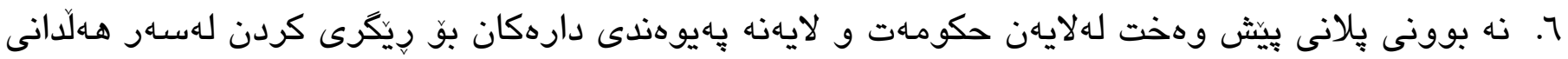

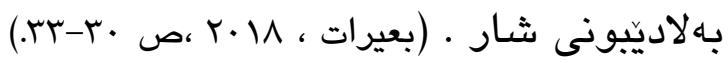

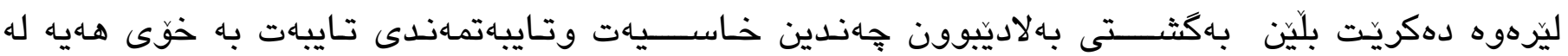

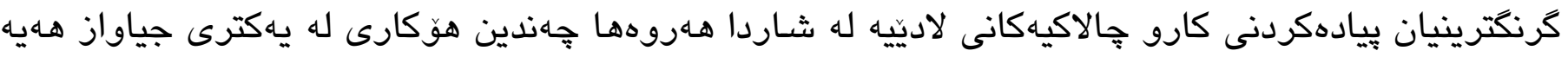

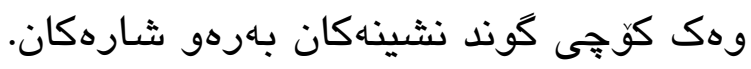

\section{بلفهى دووهم

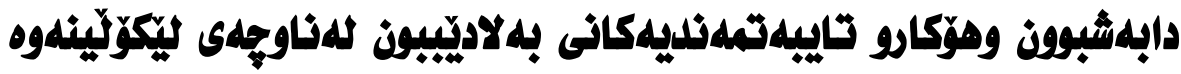

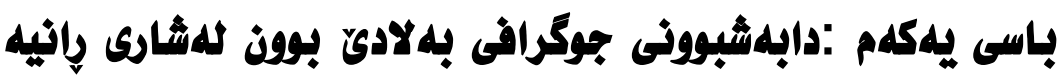

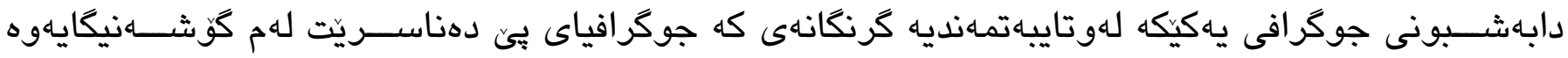

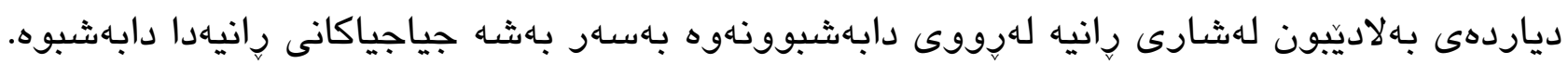

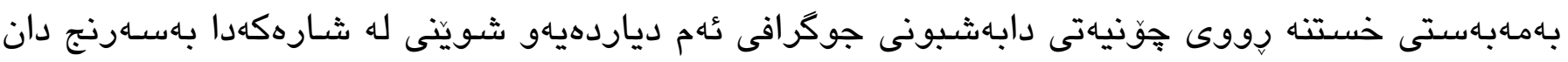

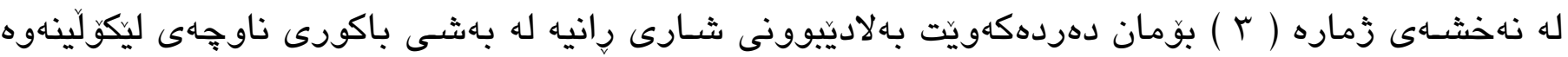

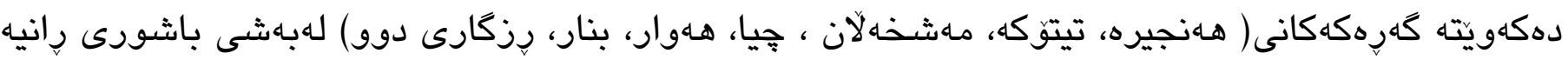

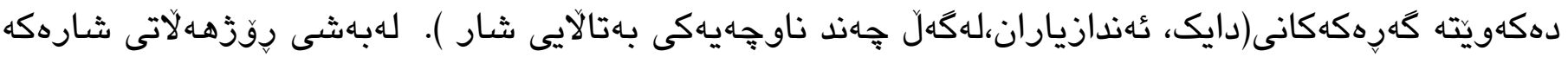

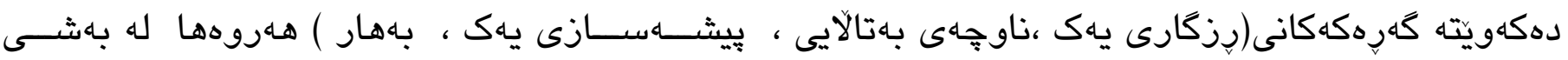

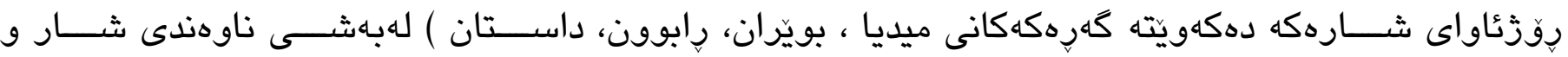

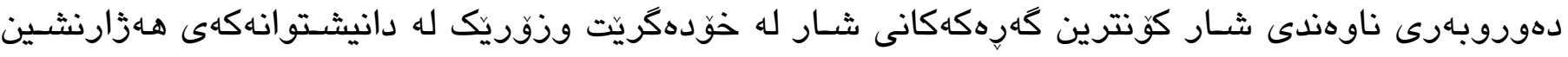

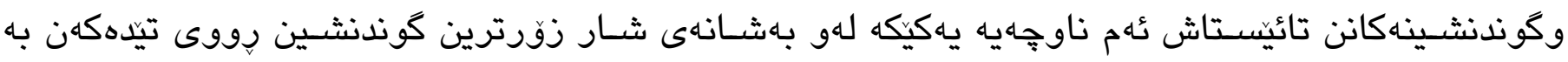

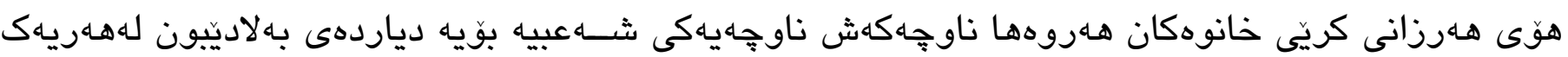

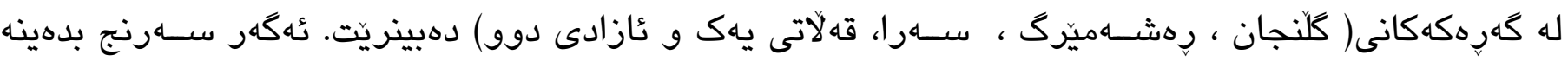

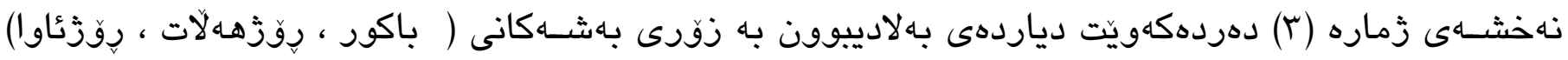

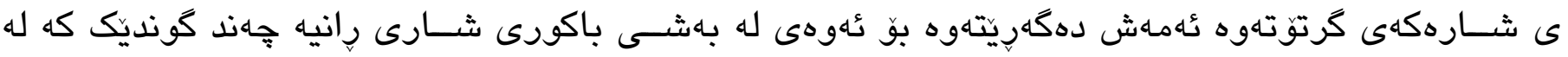

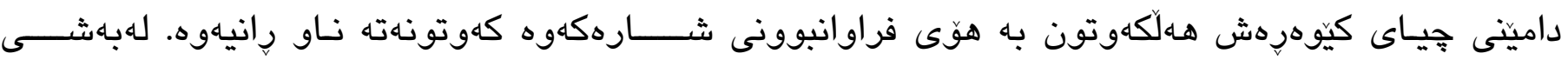

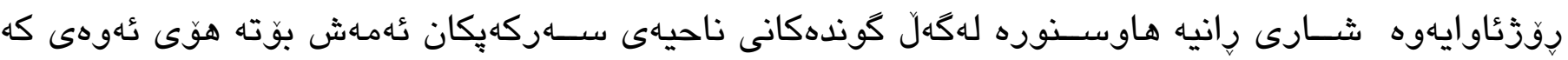

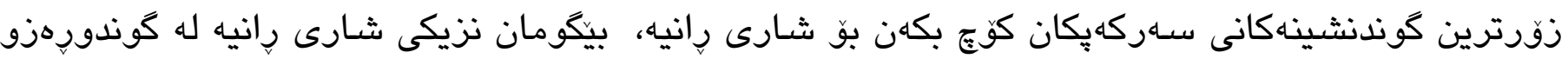

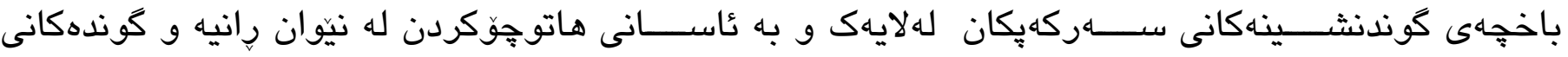

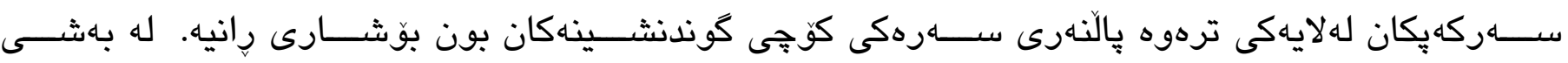

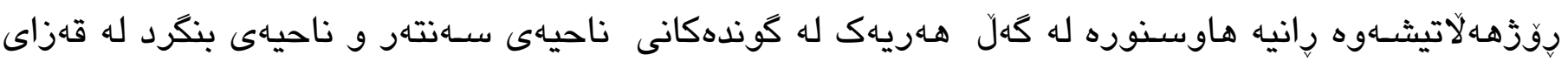

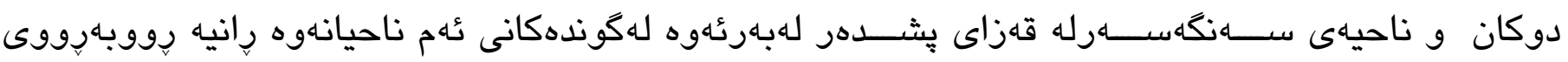




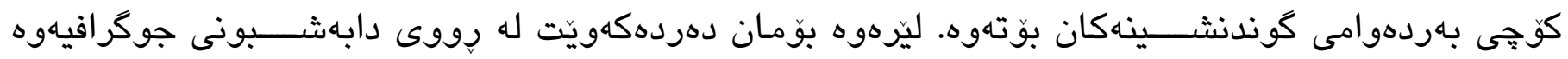

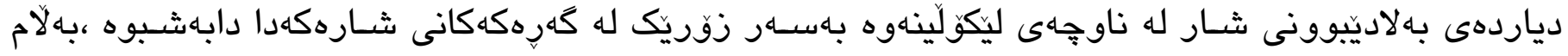

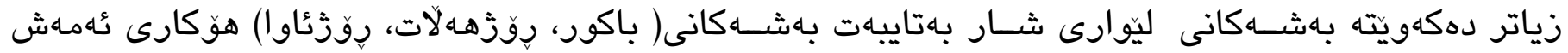

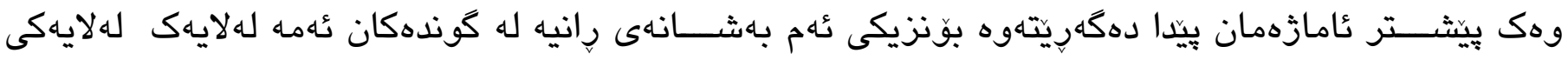

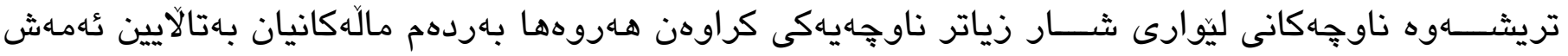

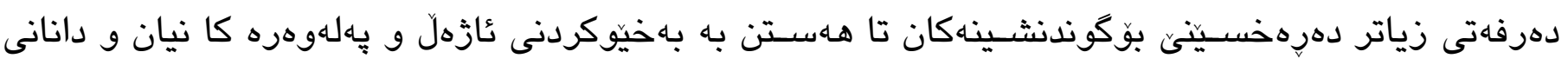

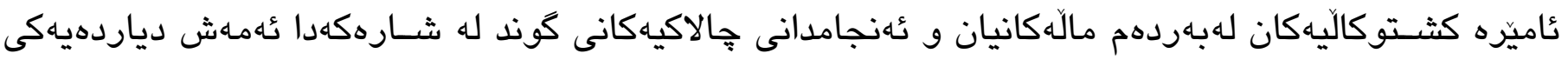

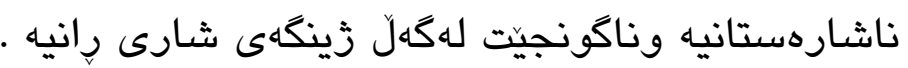

نهخشهى زُماره(

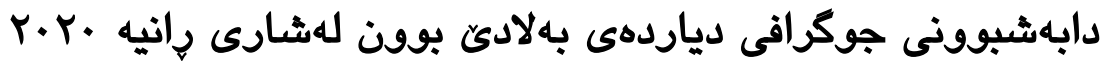

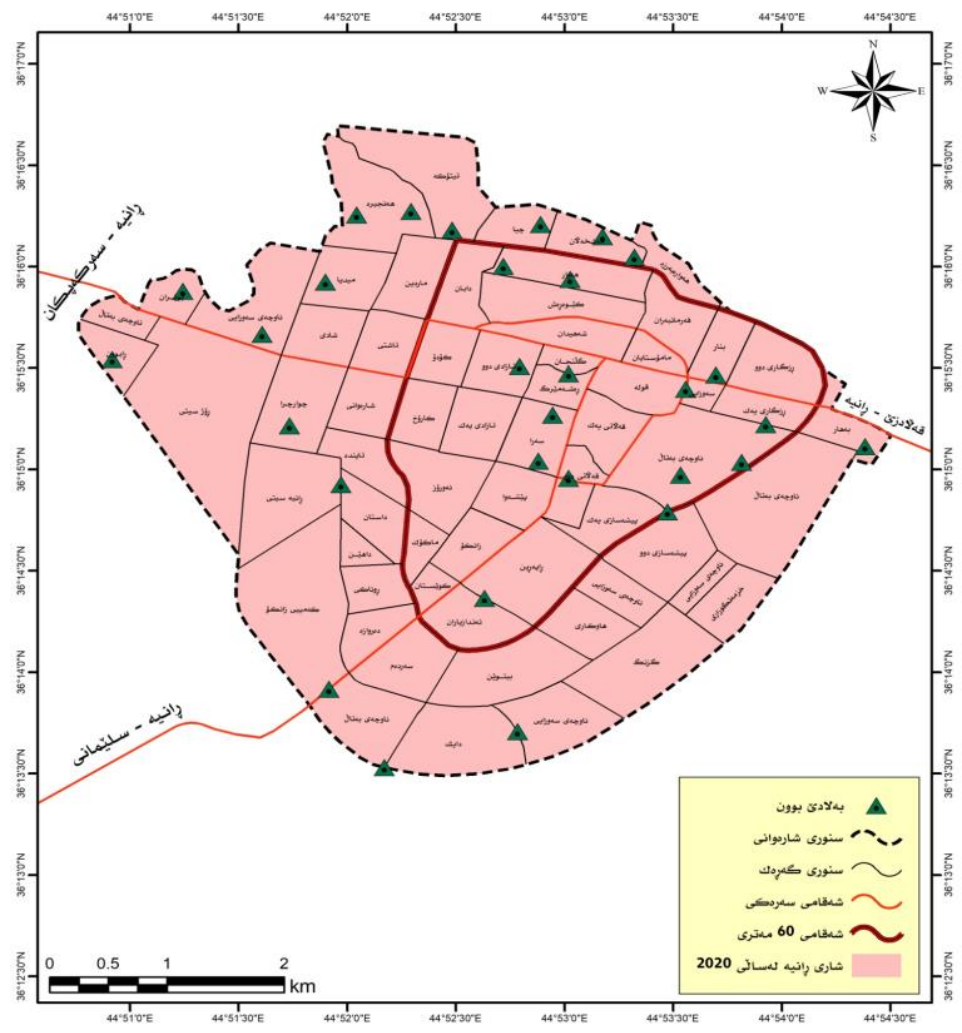

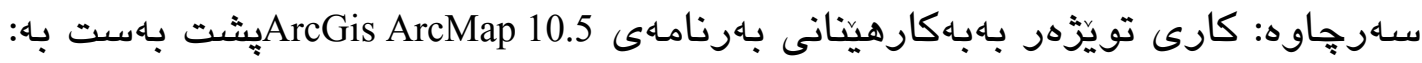

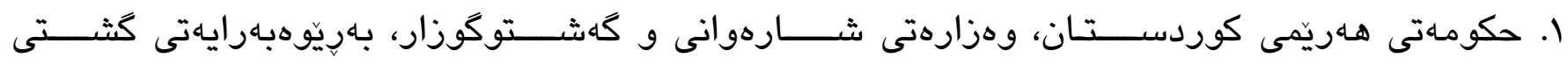

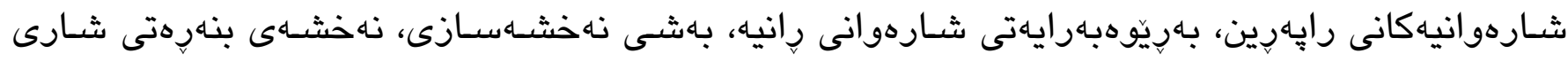

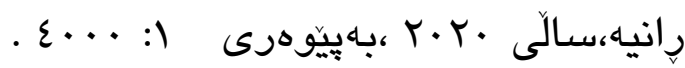

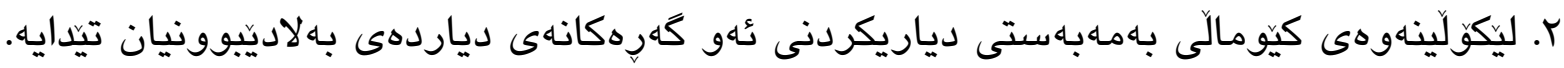

\section{باسى دووهم :هوّكارمكانى بلالاديبوذ له ثُارى رإنيه}

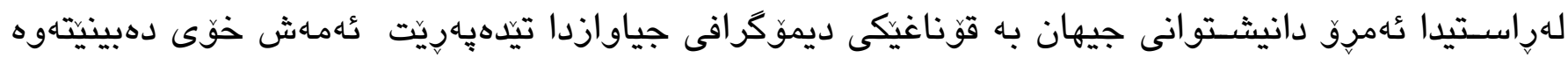

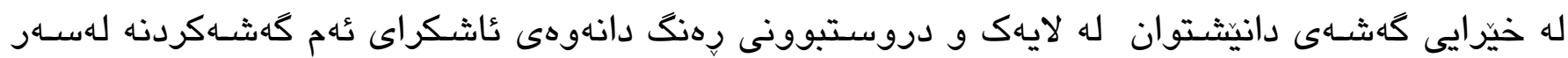

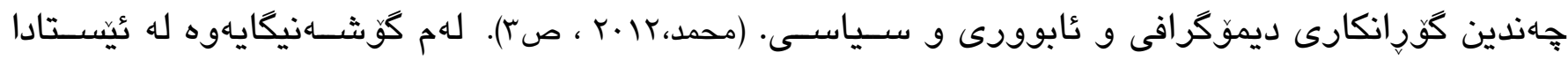




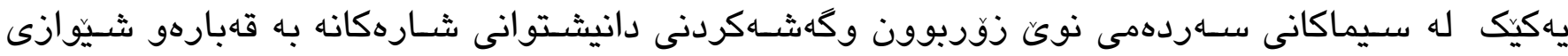

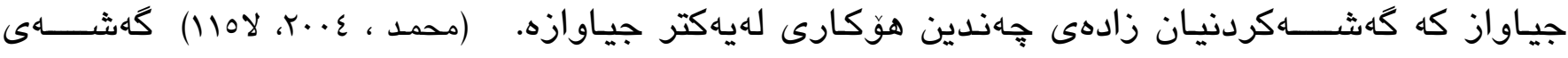

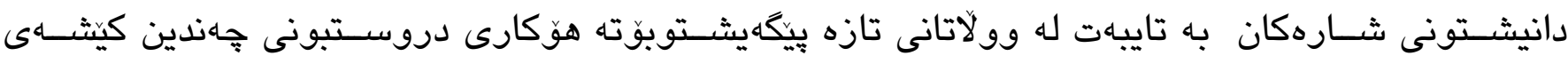

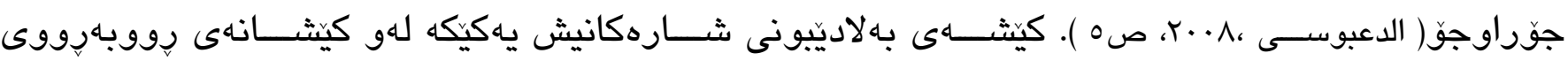

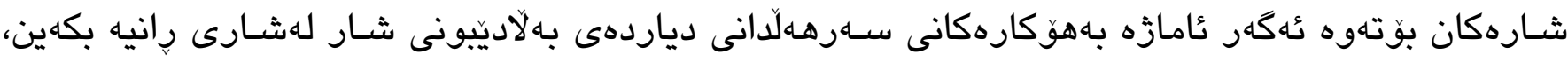

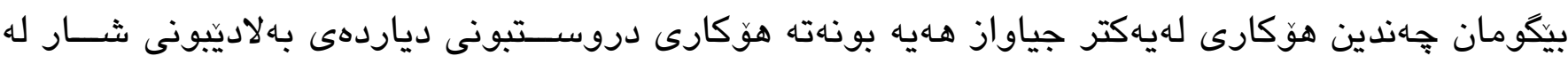

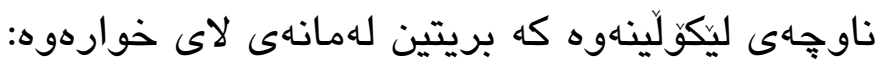

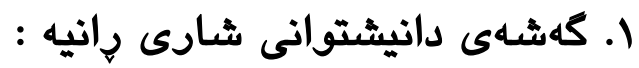

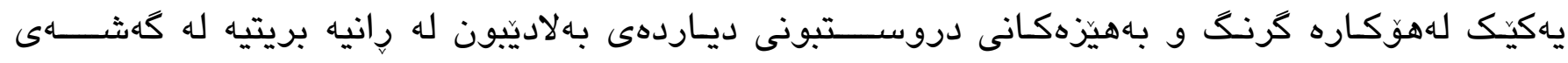

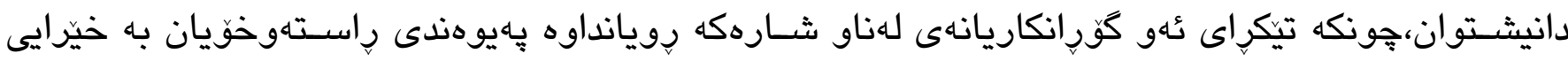

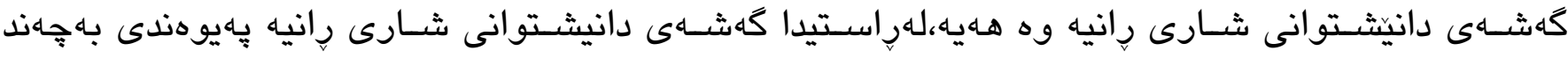

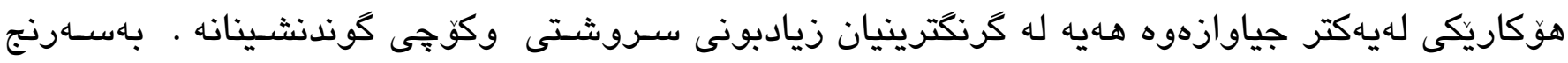

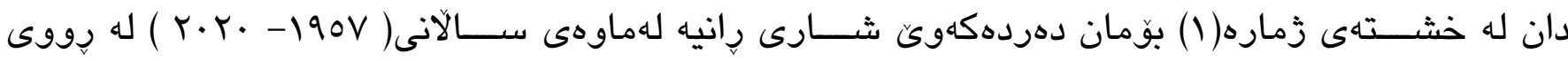

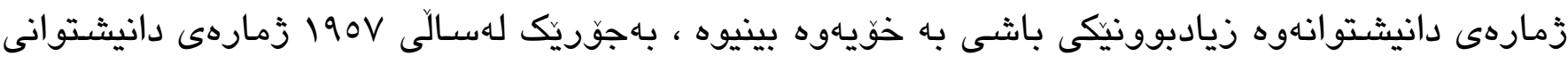

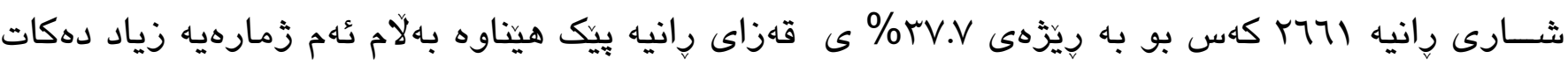

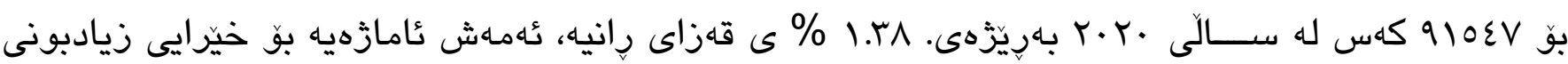

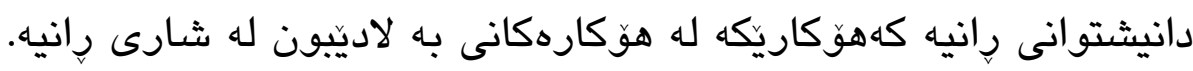

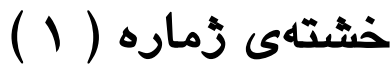

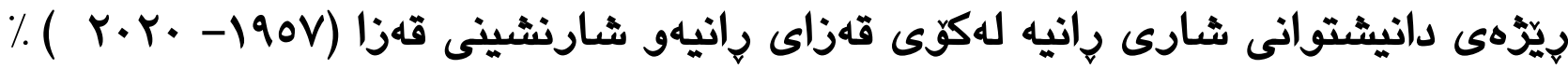

\begin{tabular}{|c|c|c|}
\hline ريّزّهى ثشار للكوَى قهزاى رانيه & دانيشتوانى ثارى رانيه & 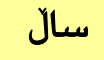 \\
\hline$V, r V$ & Yา71 & $190 \mathrm{~V}$ \\
\hline$V, 00$ & rosA & 1970 \\
\hline $17,\{7$ & AVAT & $19 W$ \\
\hline ro, $9 \varepsilon$ & rW.. & $19 \wedge \mathrm{V}$ \\
\hline TV,Vo & TIFYV & $r \cdots r$ \\
\hline ץ^,乏V & $V \varepsilon \cdot 9 r$ & $r . . q$ \\
\hline 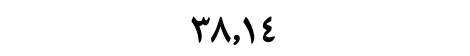 & $910 \varepsilon V$ & $r \cdot r \cdot$ \\
\hline
\end{tabular}

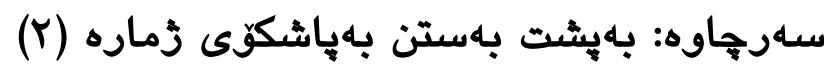

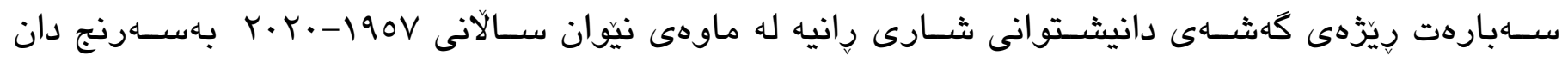

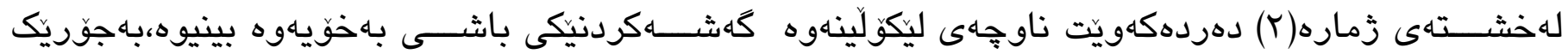

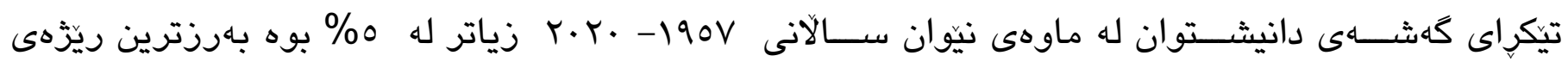

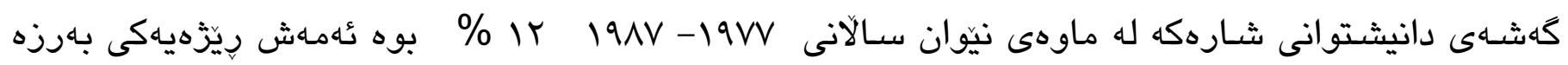

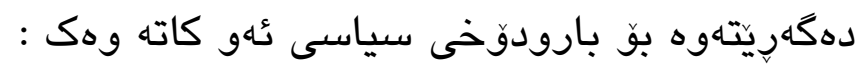

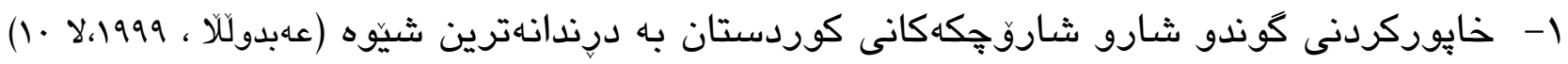




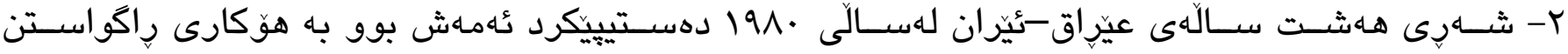

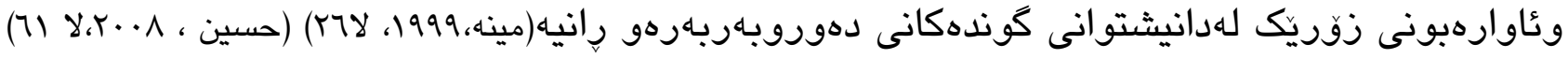

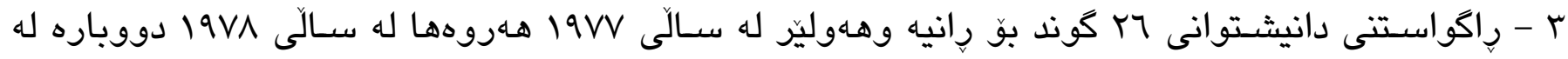

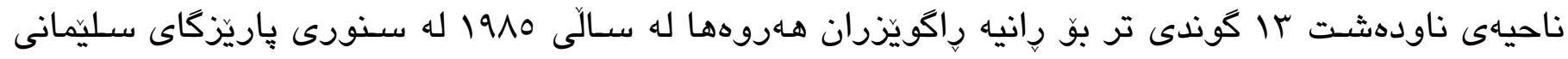

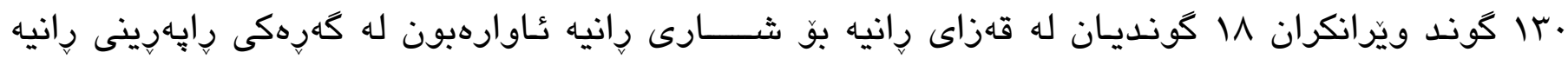

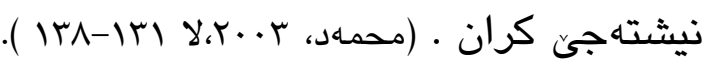

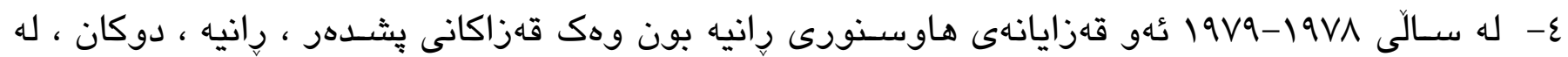

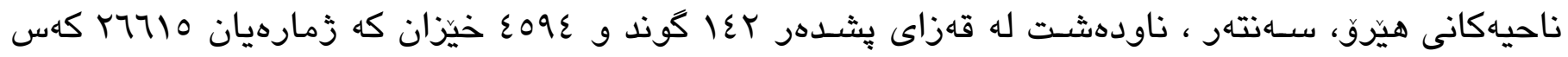

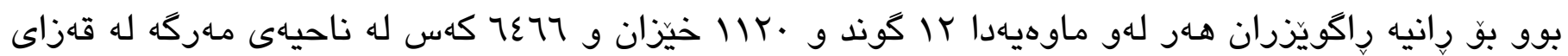

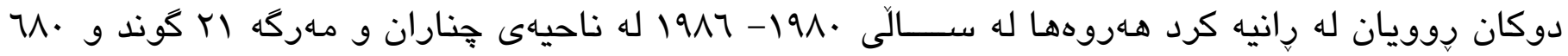

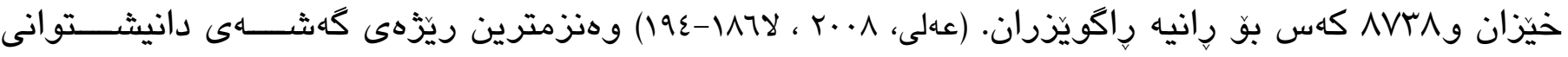

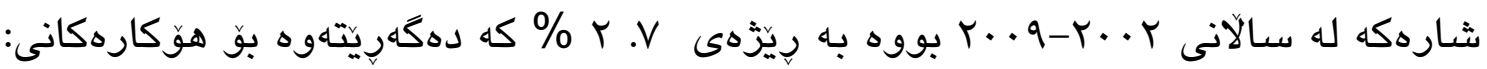

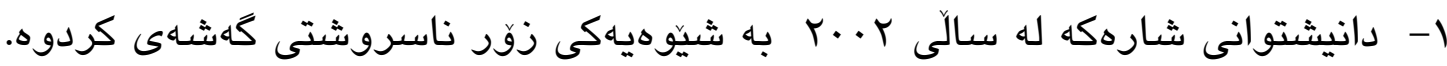

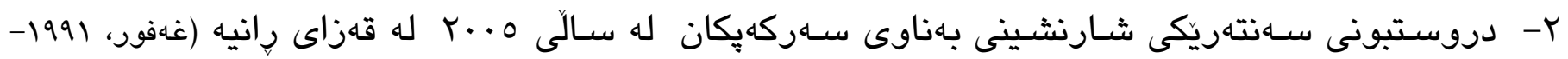

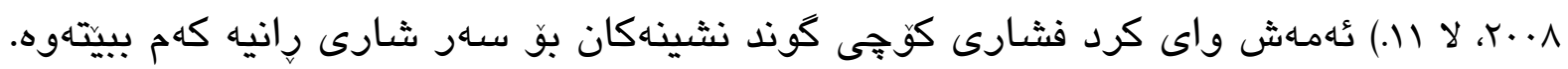

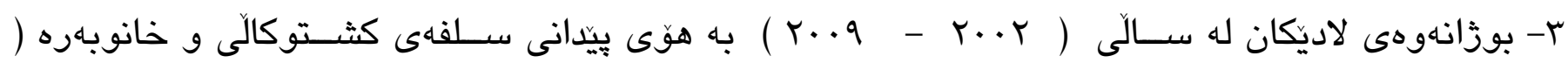

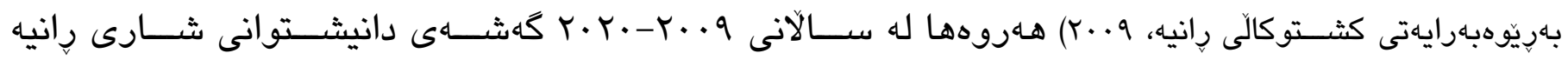

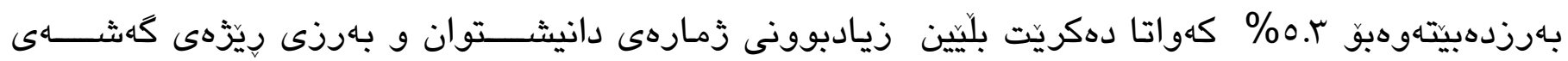

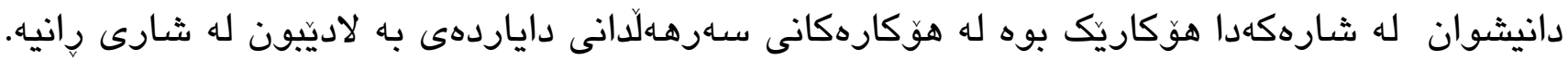

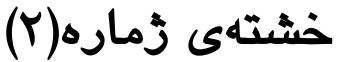

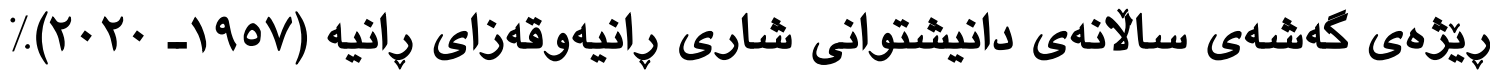

\begin{tabular}{|c|c|c|}
\hline قهزاى رانيه. & شـارى رانيه. & ماوه \\
\hline$r, r$ & $r, \eta$ & $1970-190 \mathrm{~V}$ \\
\hline 1 & $\mathrm{~V}, \Lambda$ & $19 W-1970$ \\
\hline$r, V$ & $\mid Y, 1$ & $191 \mathrm{~V}-19 \mathrm{VV}$ \\
\hline 0 & $0, \varepsilon$ & $r \cdot r-19 \wedge V$ \\
\hline$r, \varepsilon$ & $Y, V$ & $r \ldots q-r \cdots r$ \\
\hline$r, V$ & r,o & $r \cdot r \cdot-r+\cdot q$ \\
\hline$r, M$ & 0,10 & $r \cdot r \cdot-190 V$ \\
\hline
\end{tabular}

سهرجاوه: بهبشت بهستن بهاشكونى زُماره (Y).

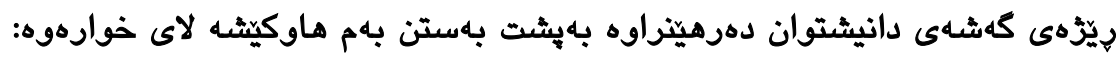
$r=\left\{T \sqrt{\frac{p 1}{p 0}}-1\right\} \times 100$

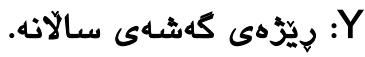

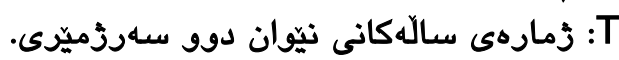
P1

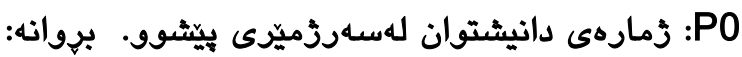
John I Clarkk, Population Geography, $2^{\text {nd }}$ Edition, Pergaman Press .Oxford, 1972, P146. 


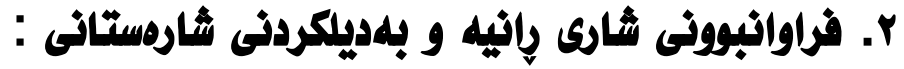

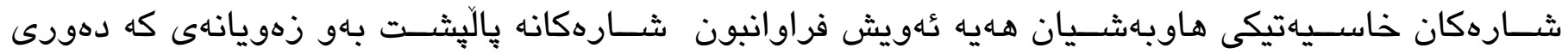

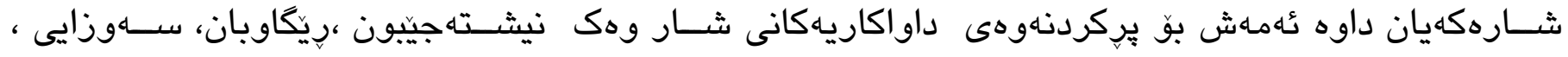

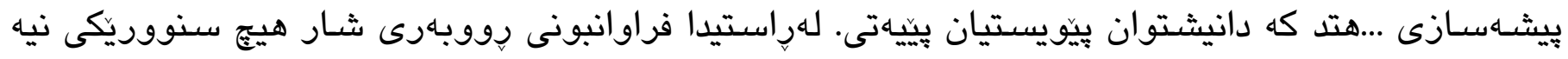

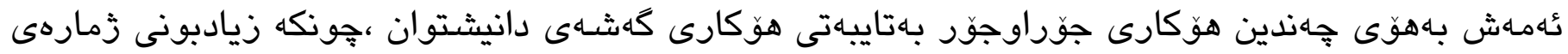

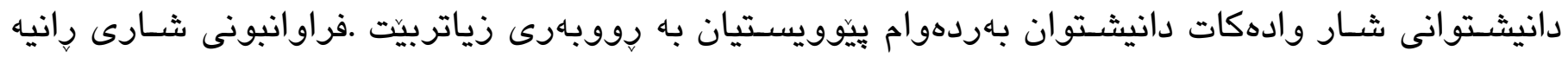

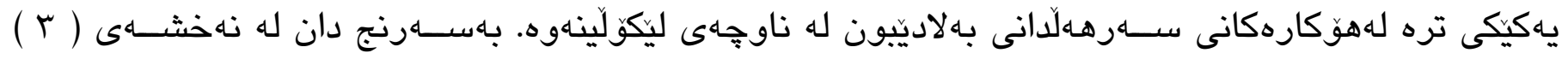

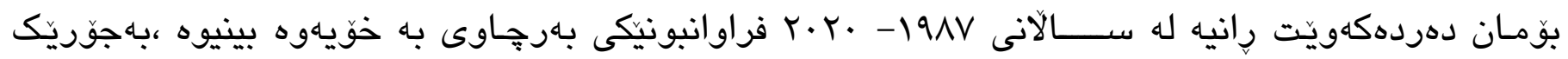

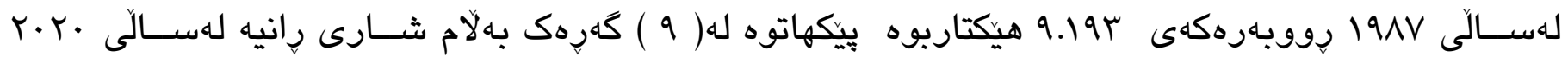

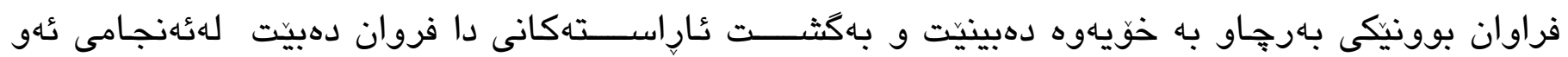

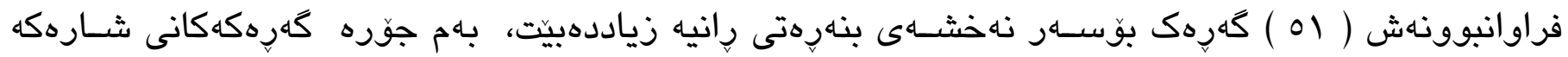

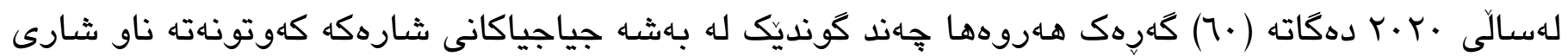

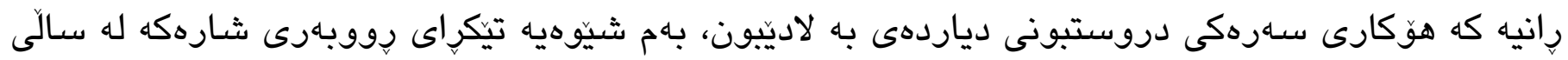

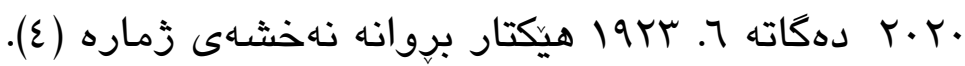

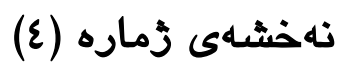

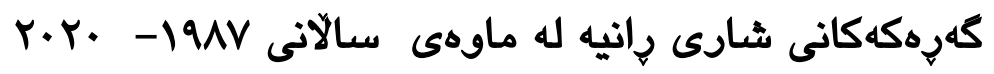

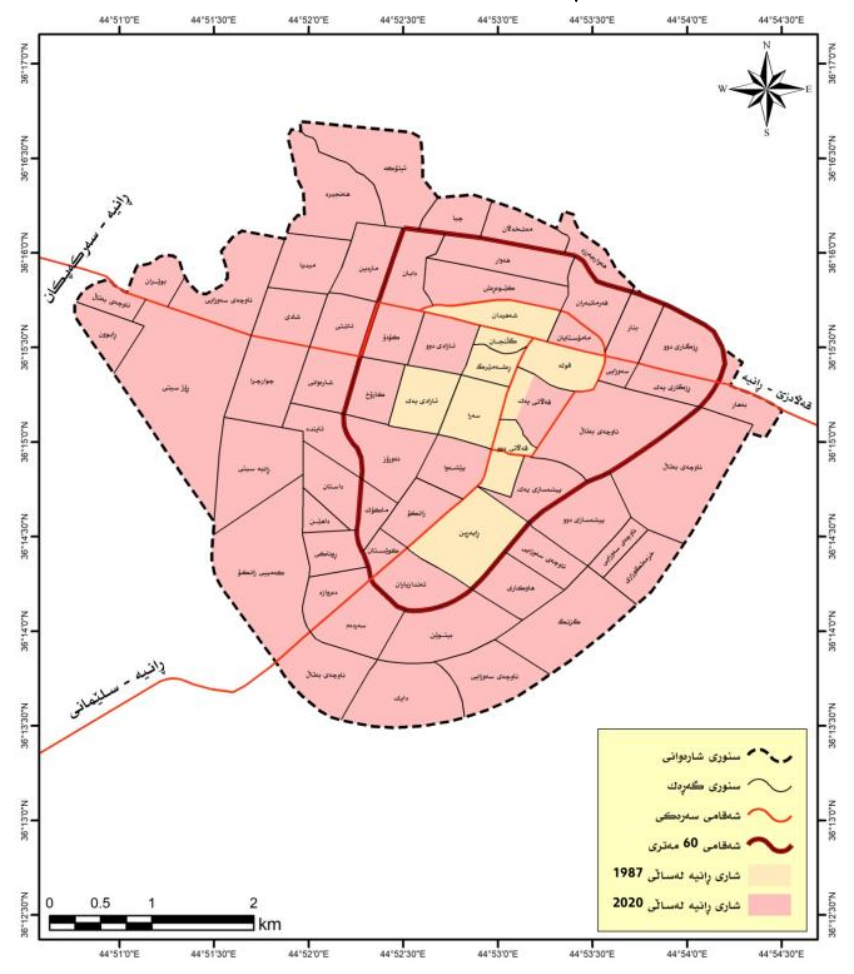

سهارجاوه: كارى تويّزّهر بهبه كارهينانى بهرنامهى 10.5 ArcGis ArcMap يُشت بهست به:

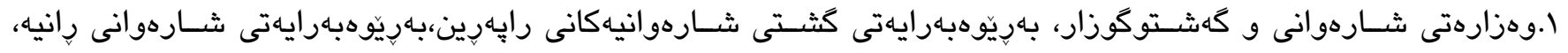

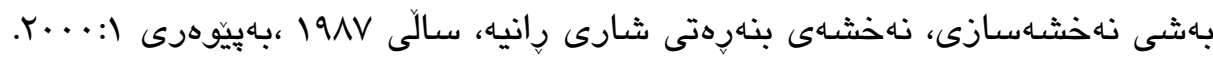




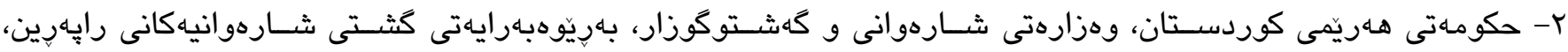

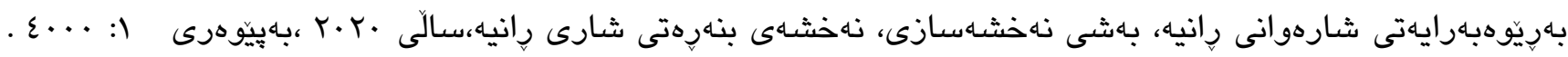

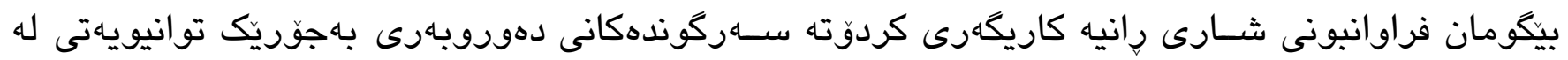

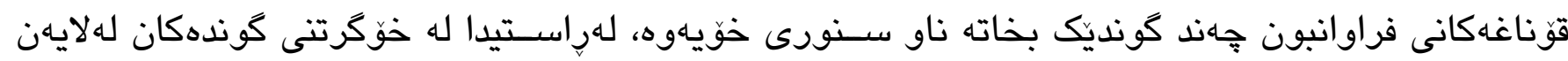

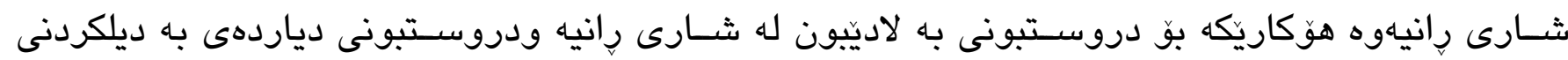

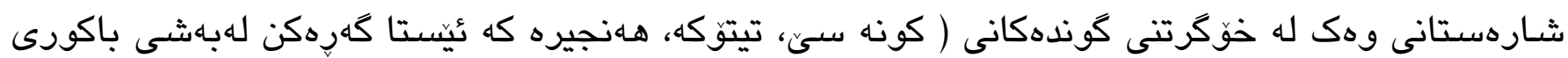

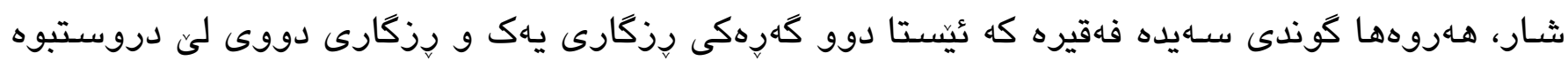

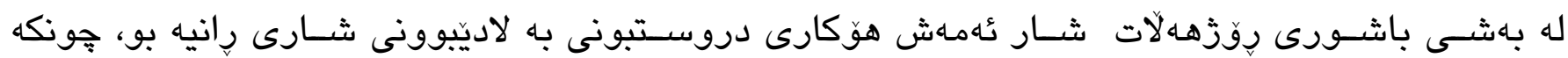

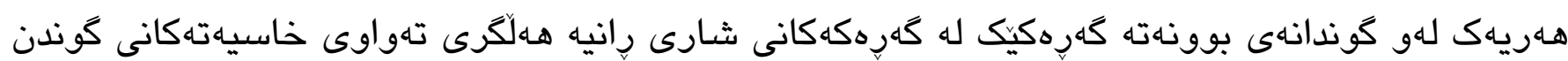

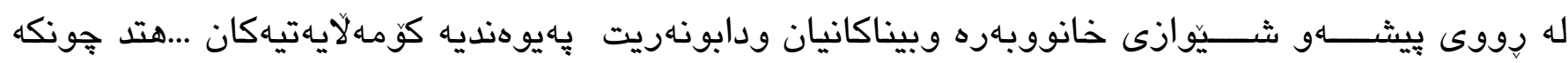

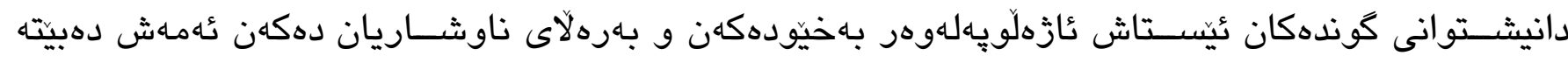

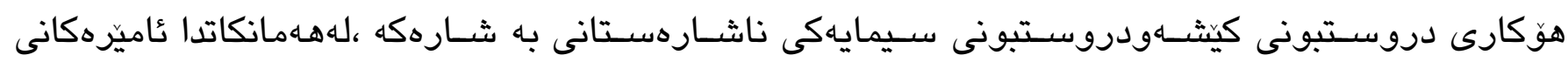

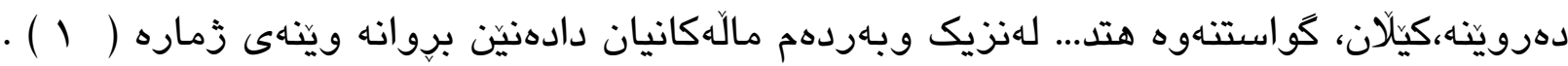

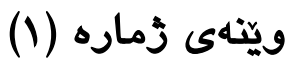

بهرهلاكردنى عازٔهلهكان و له وهراندنيان له ليّار وناره
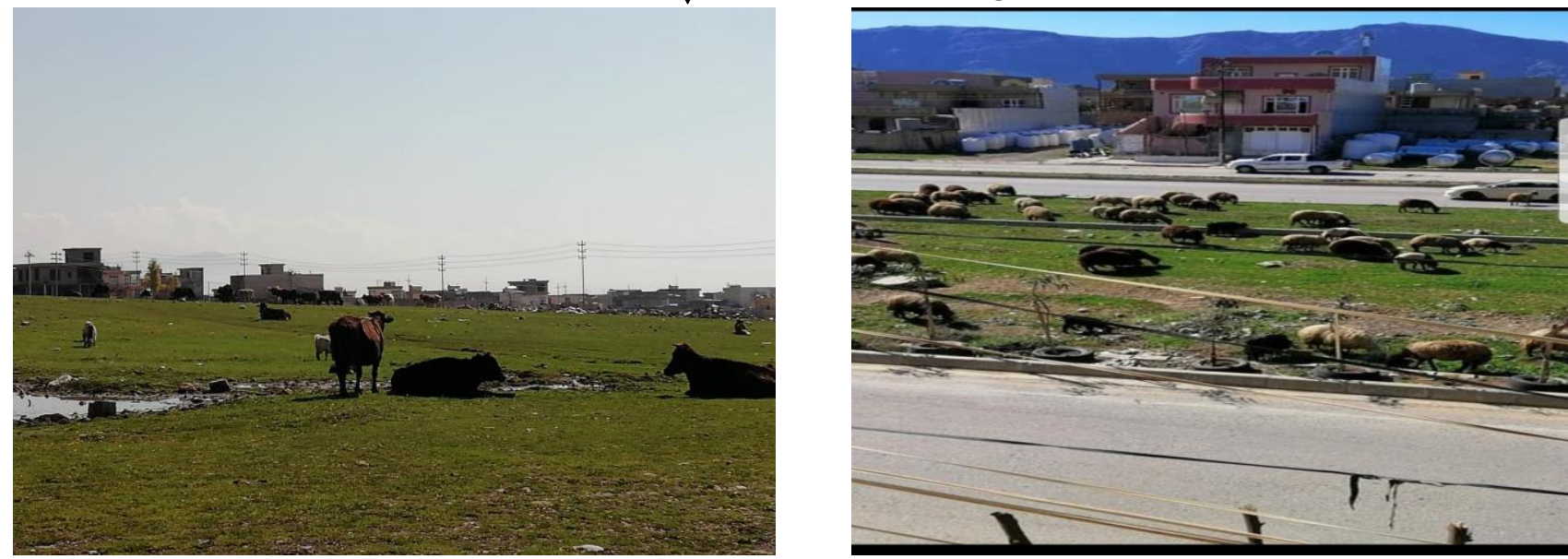

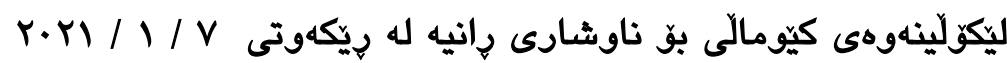

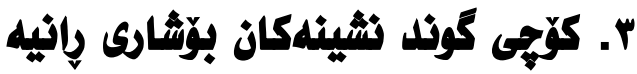

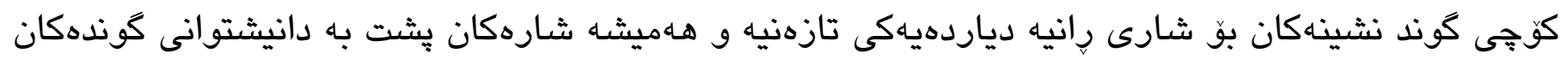

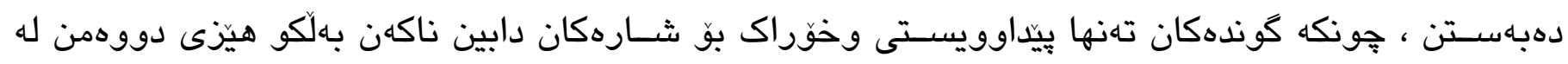

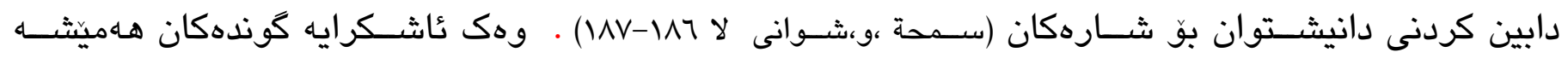

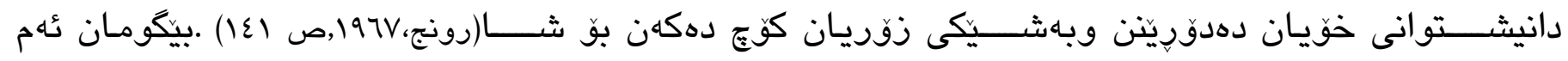

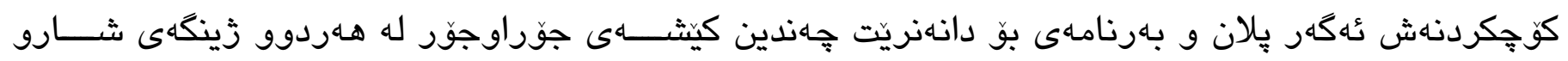

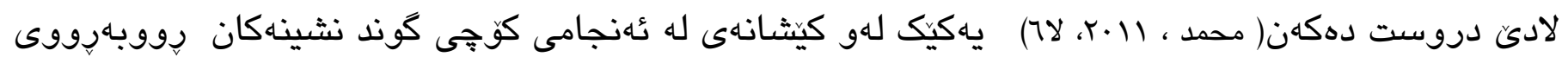

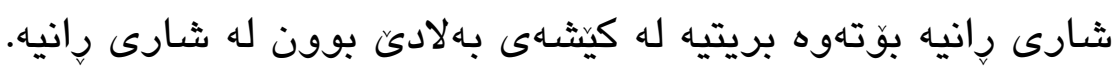




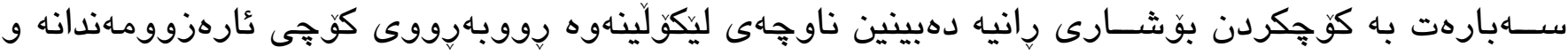

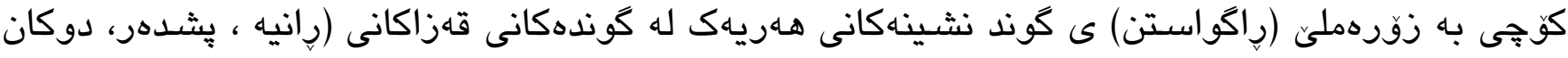

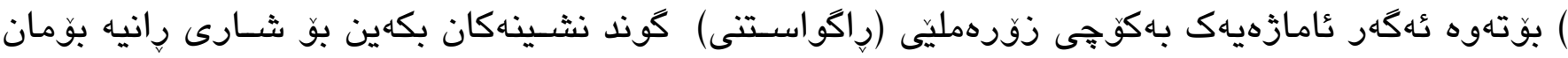

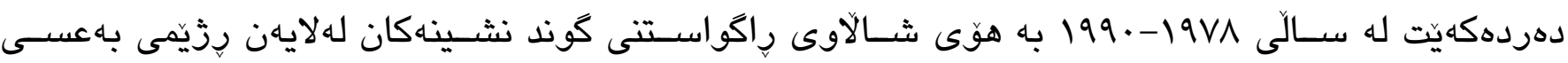

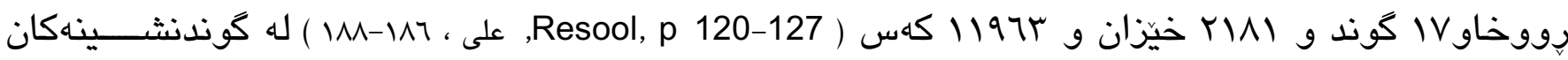

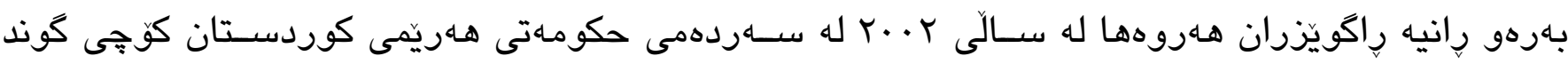

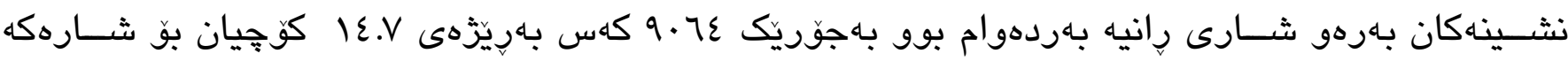

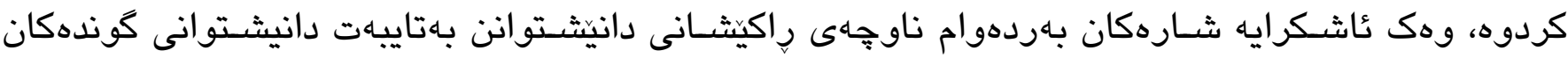

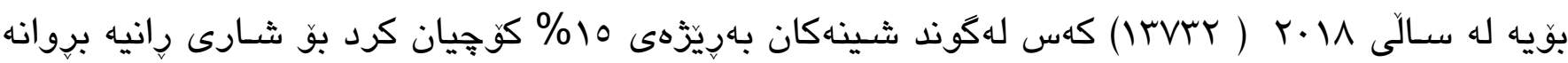

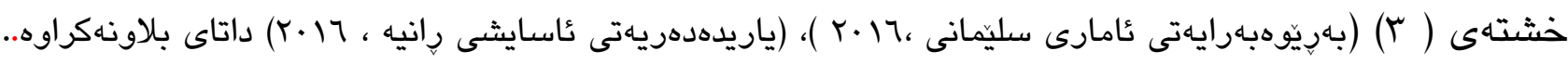

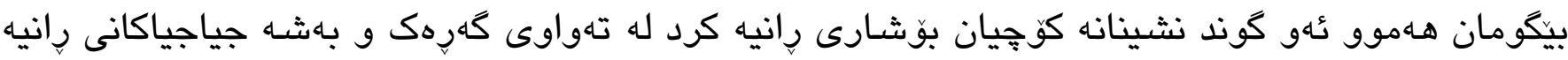

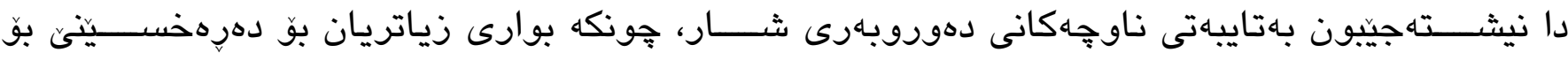

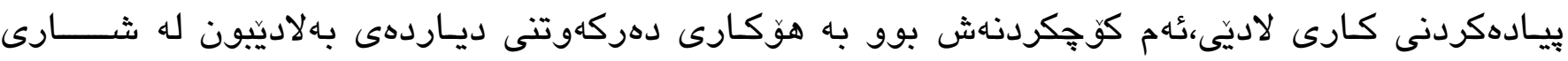

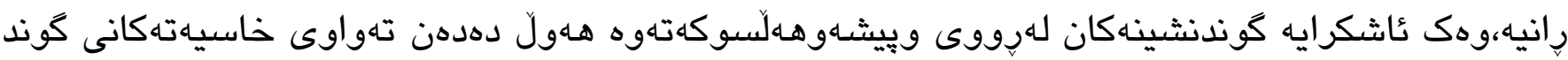

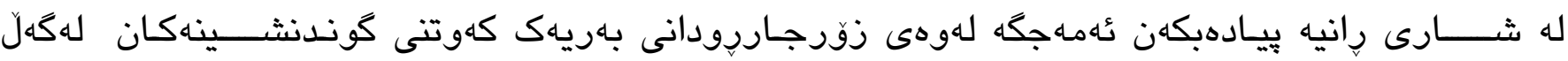

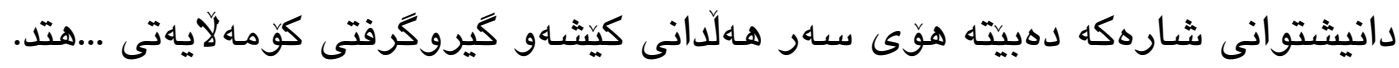

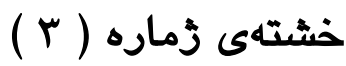

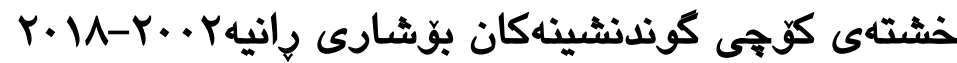

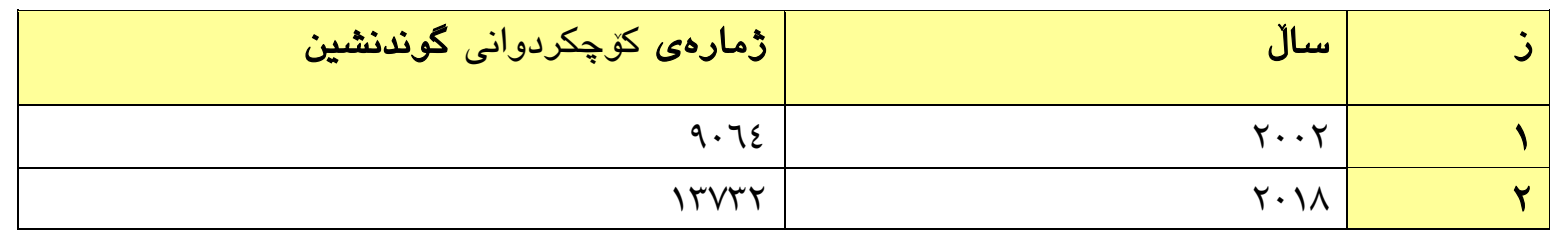

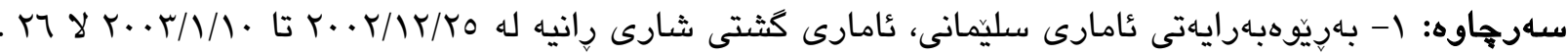

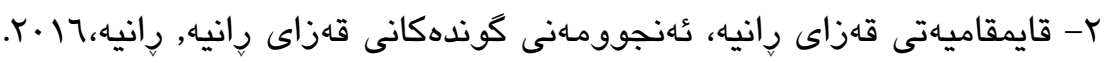

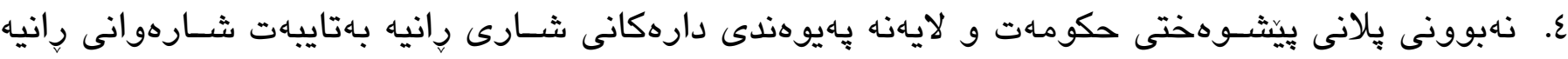

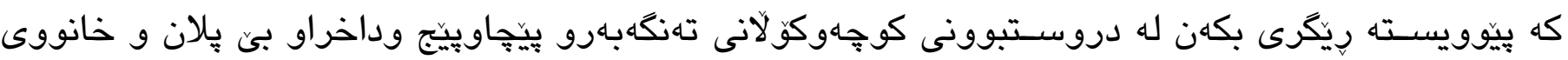

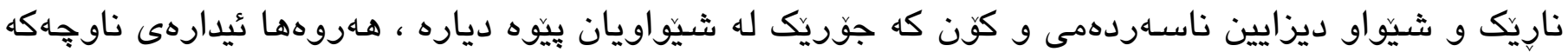

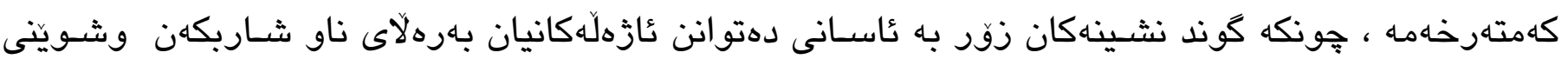

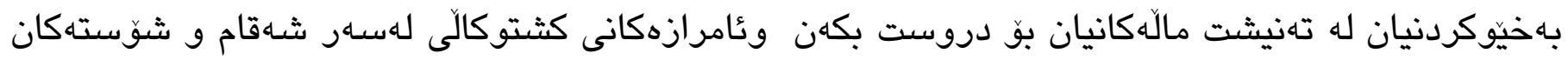

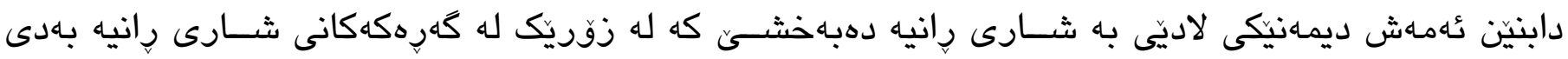

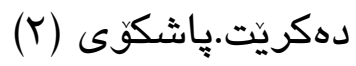

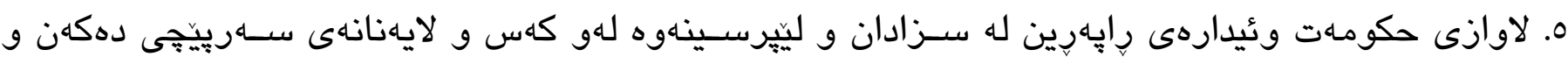

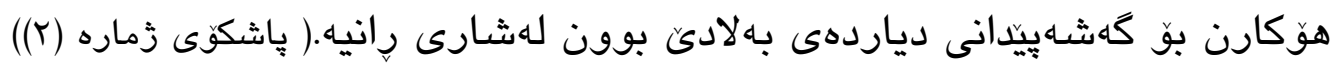

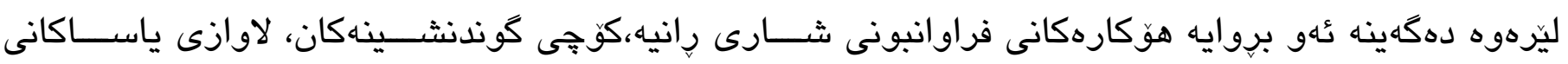

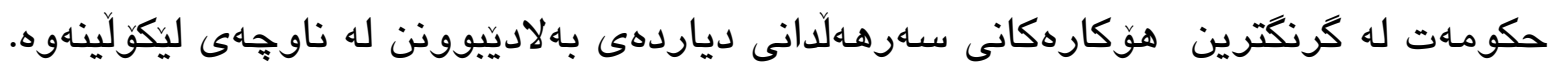




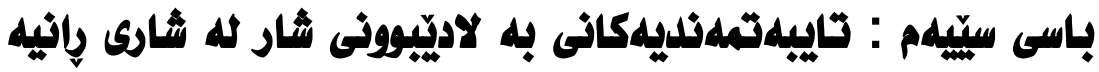

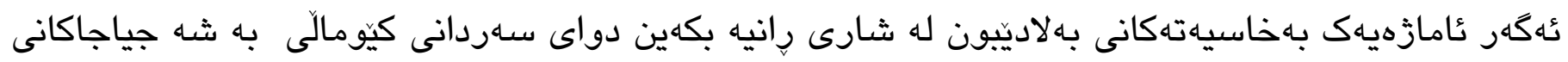

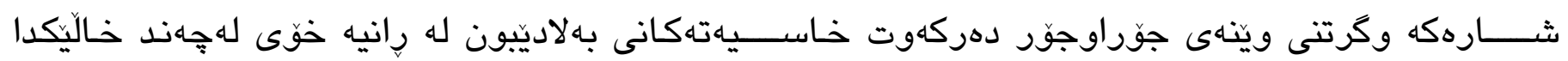

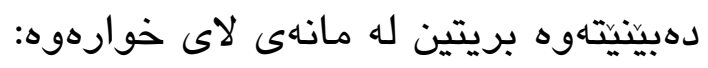

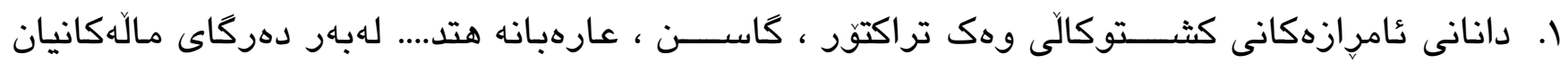

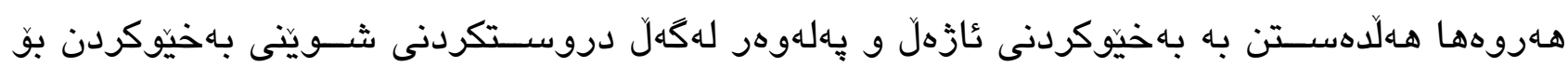

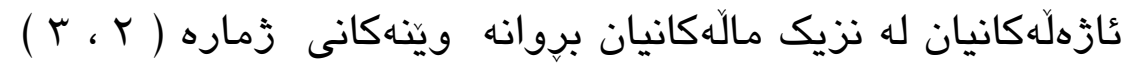

\section{وينئه زماره (Y)}

دانانى ئاميّره كشتوكاليهكان لهبهردهم مالَ
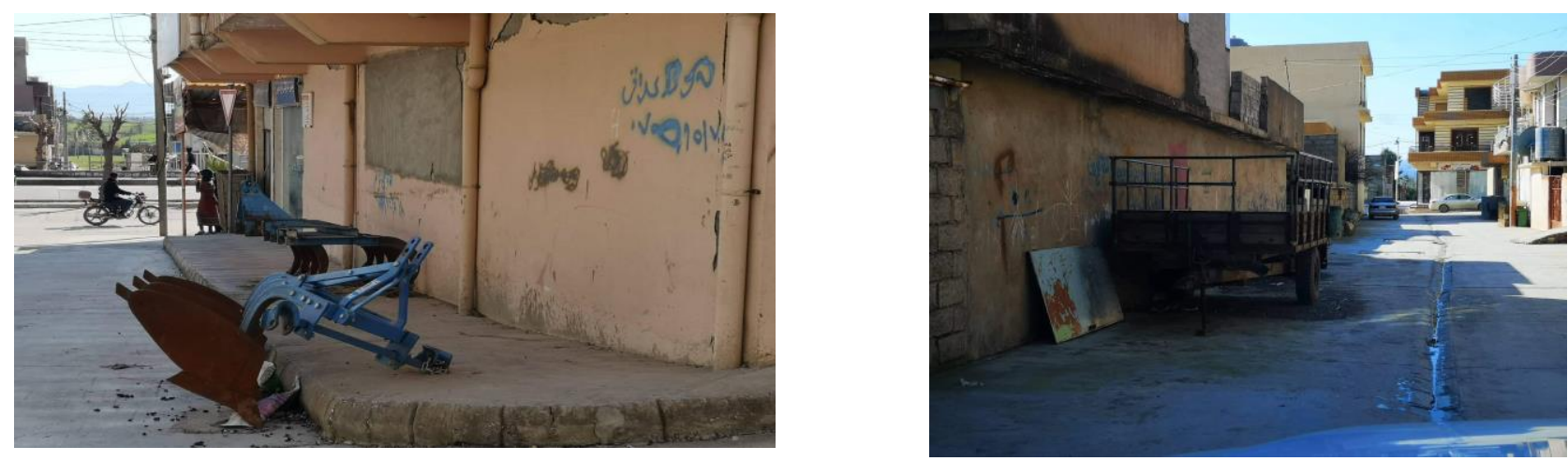

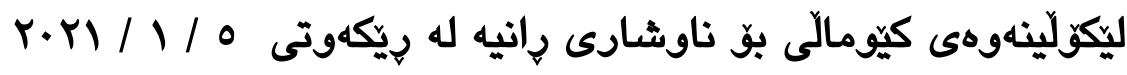

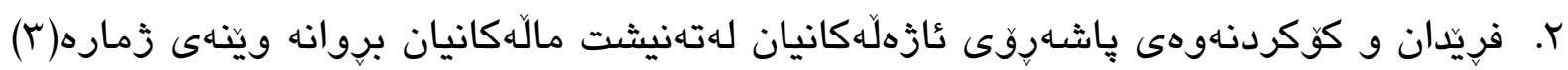

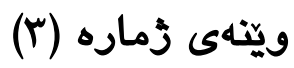

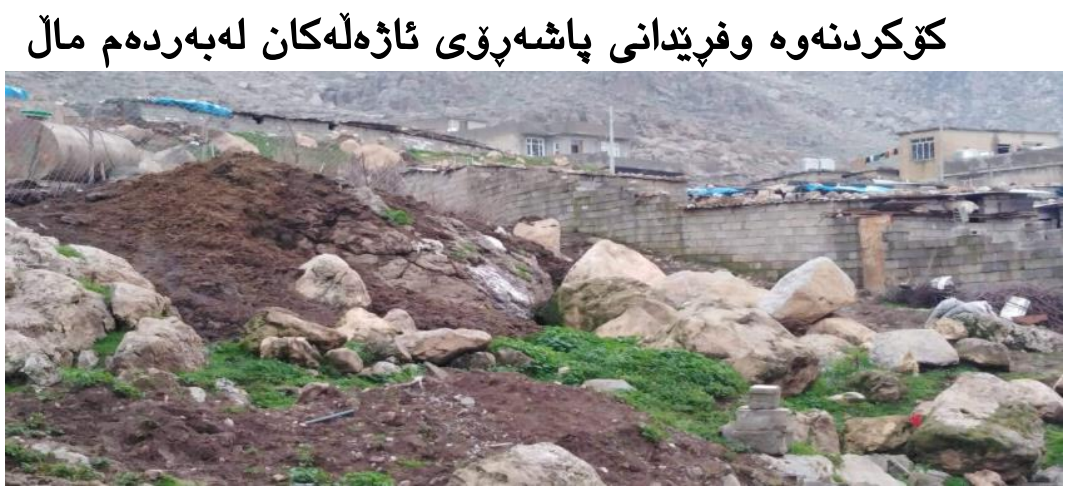

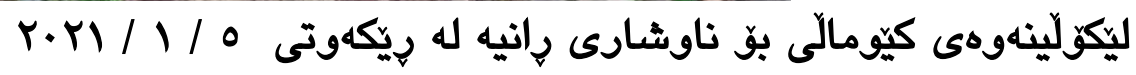

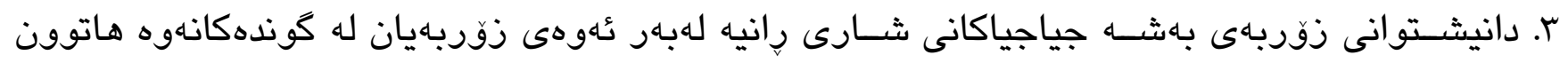

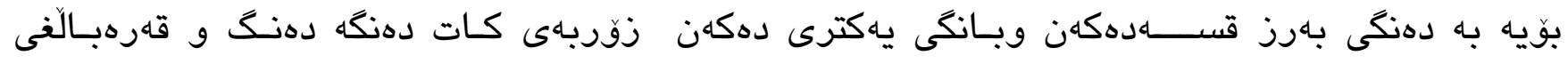

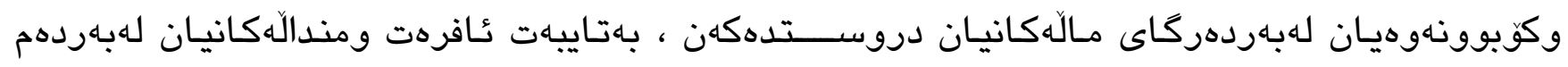

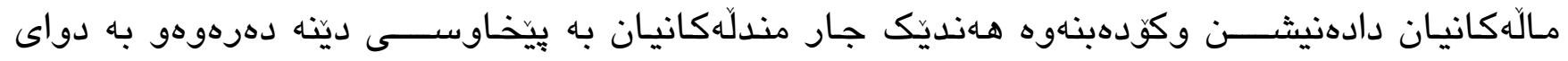

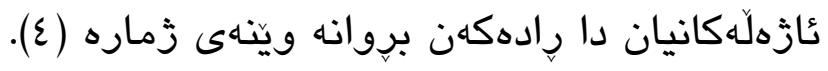




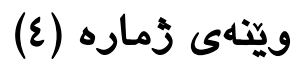

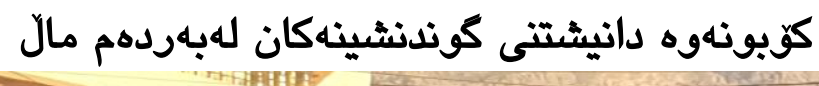

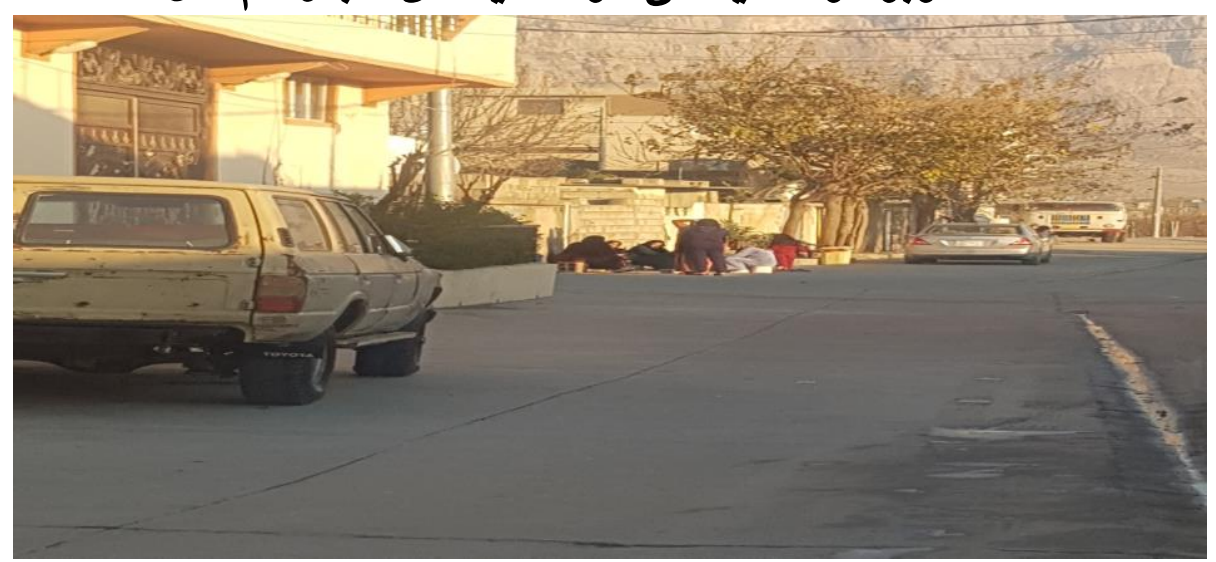

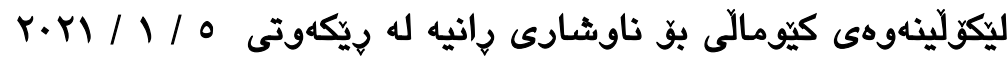

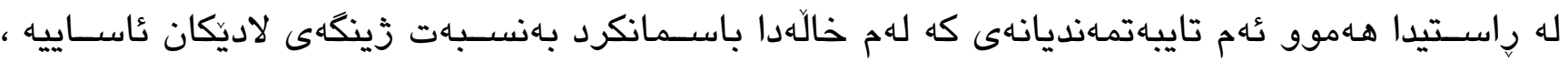

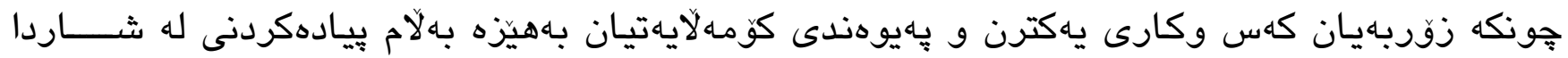

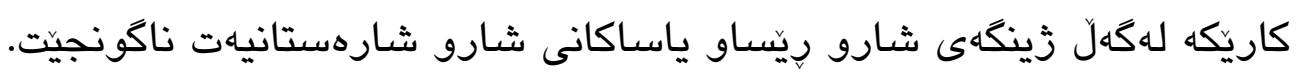

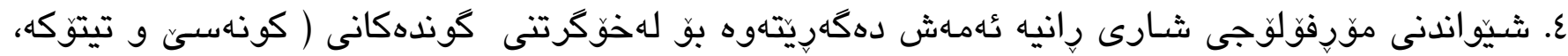

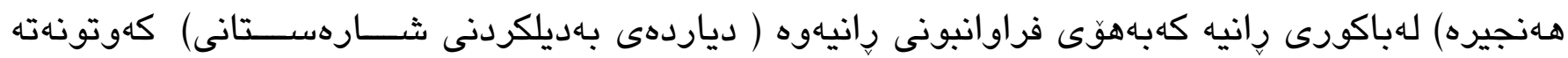

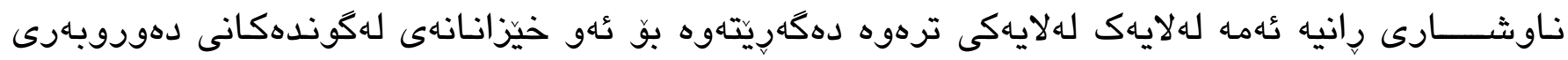

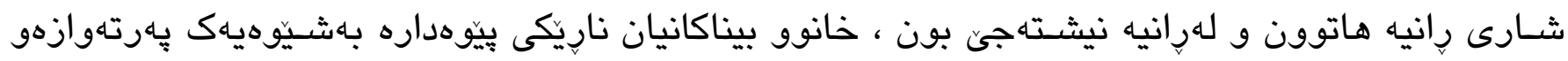

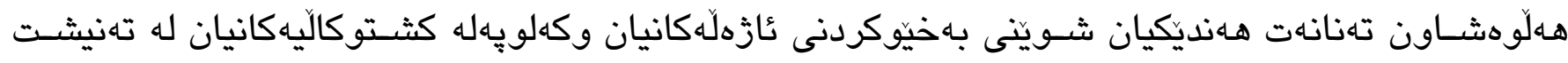

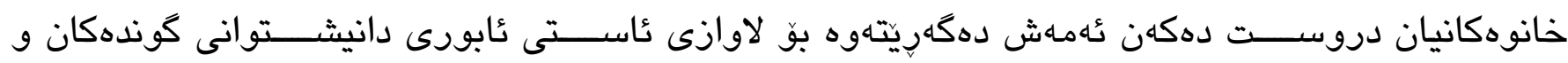

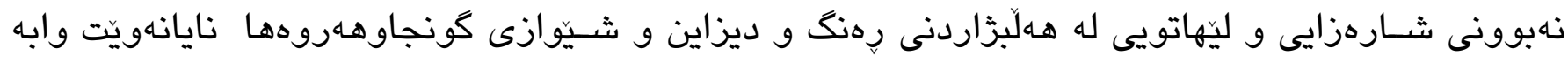

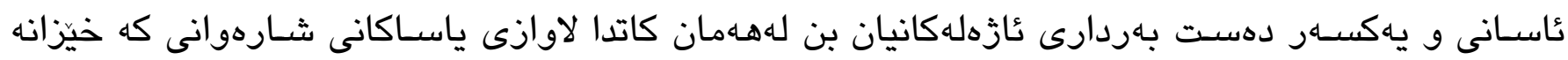

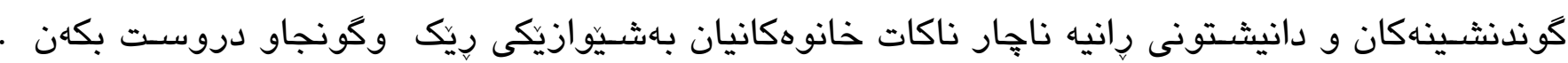

\section{وينّه زماره ( )}

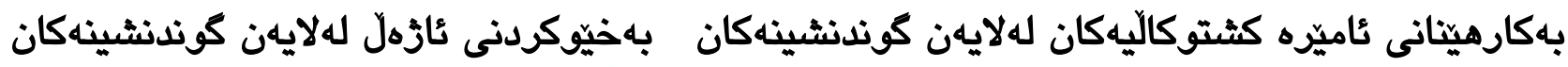

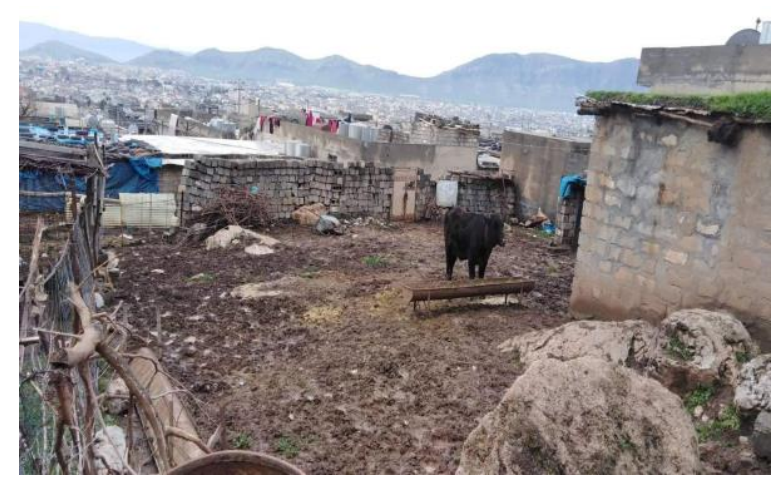

Tnentint

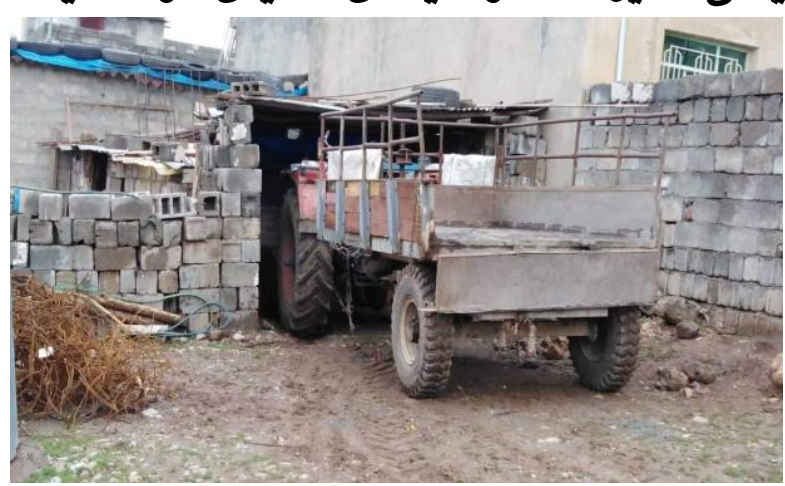

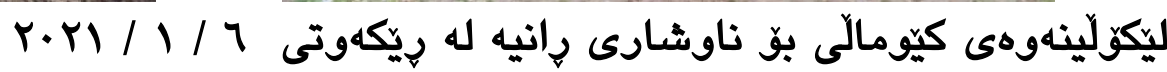


وينّهى زماره ( 7 (

خانوى ناريكي وشيّاو زيادهرويى لهشيّيوهى كرتنى شهارهامهان
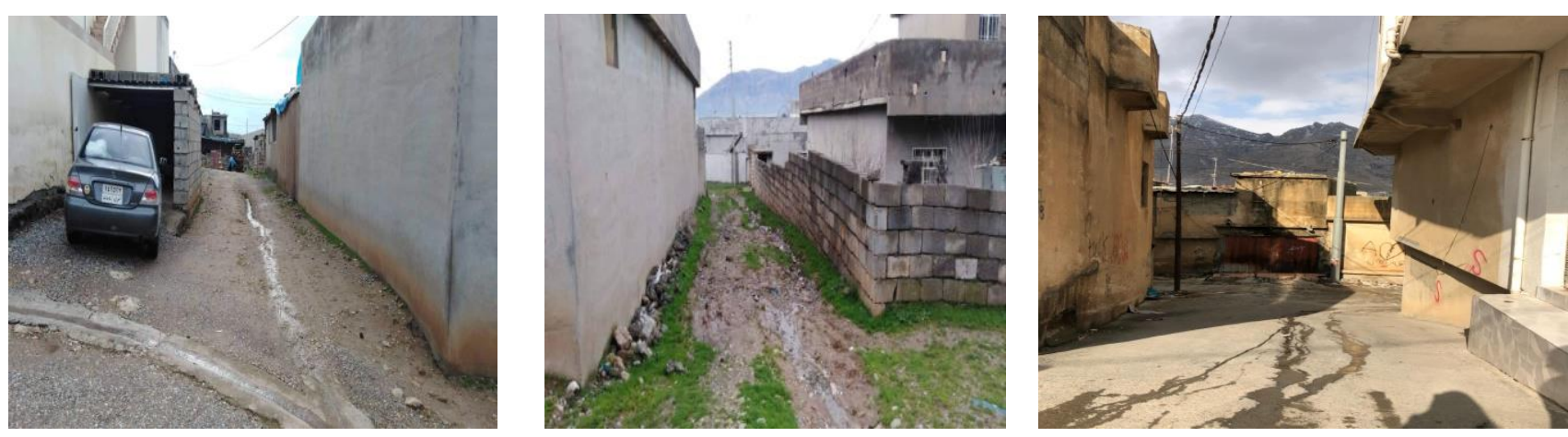

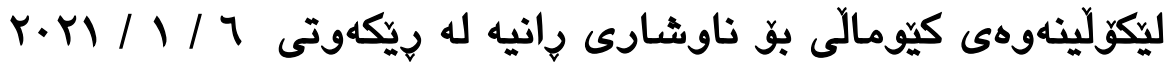

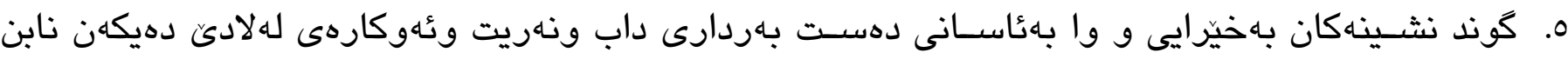

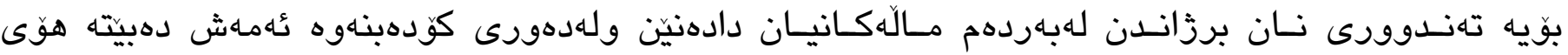

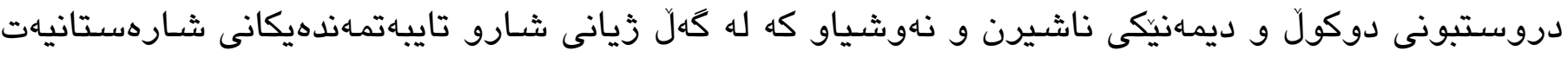

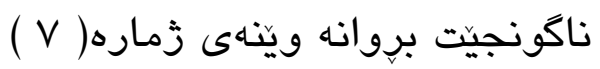

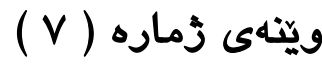

دانان و بهكارهينانى تهندورى نان برذاندن له بهرده لهم مالدكانيان لهرانيه

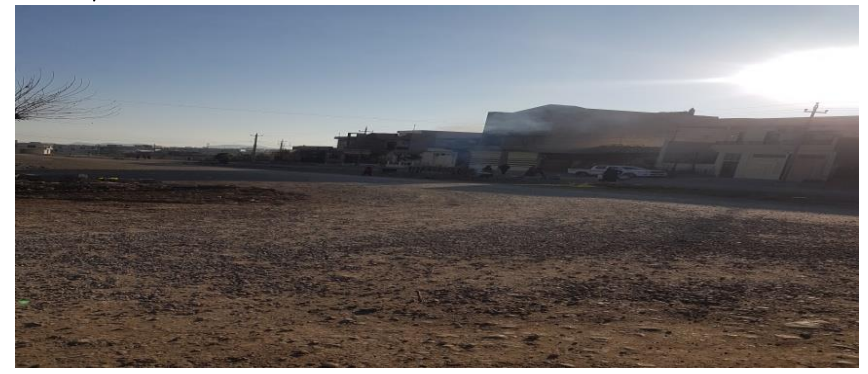

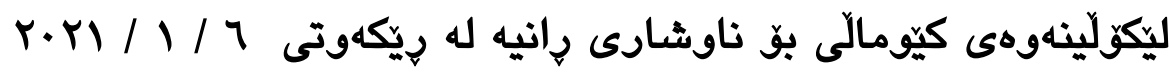

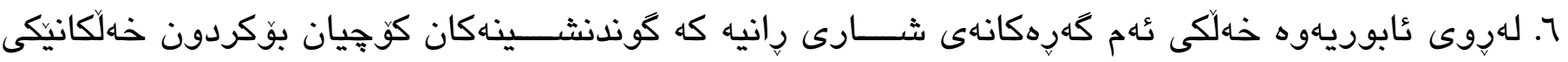

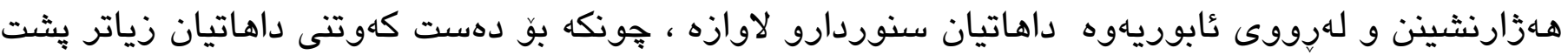

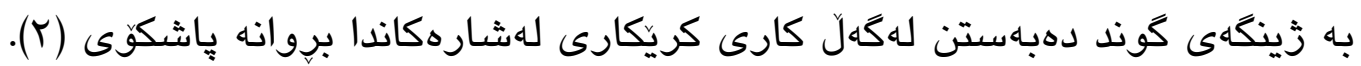

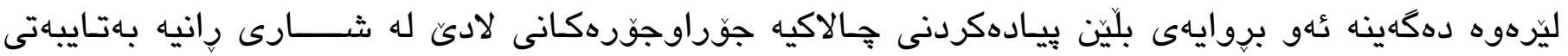

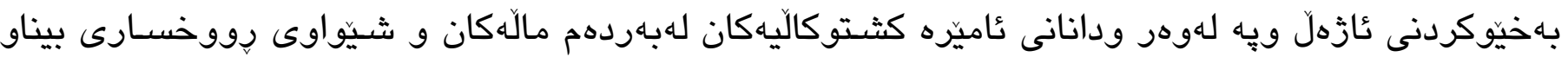

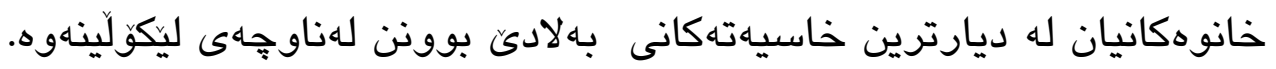




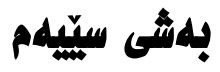

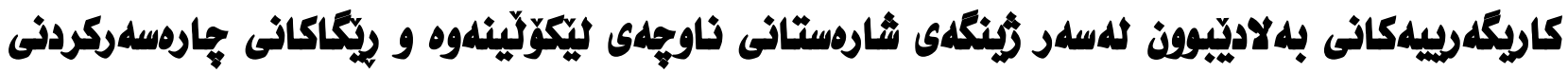

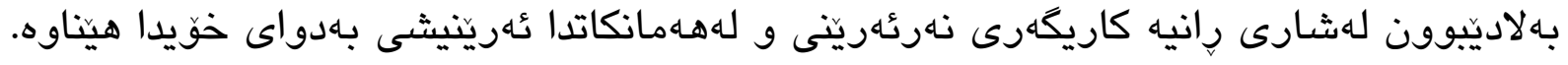

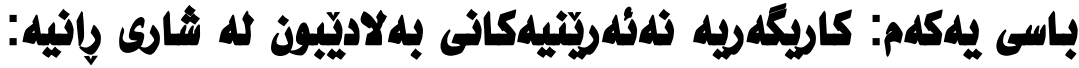

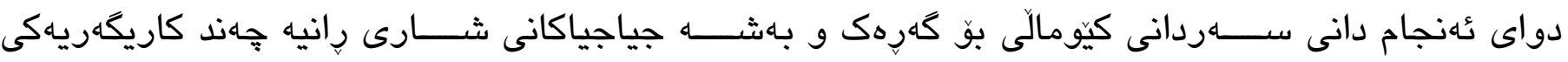

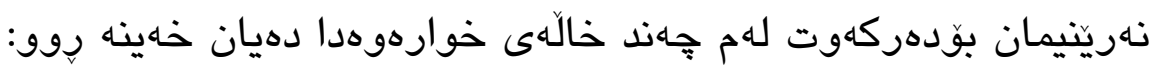

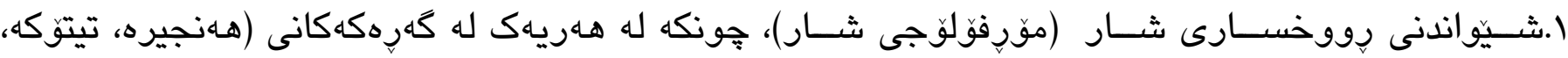

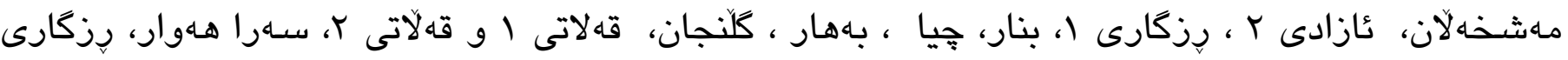

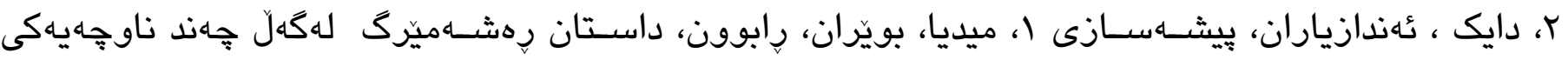

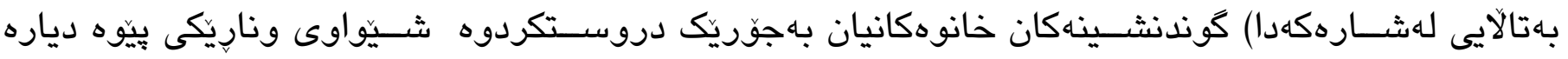

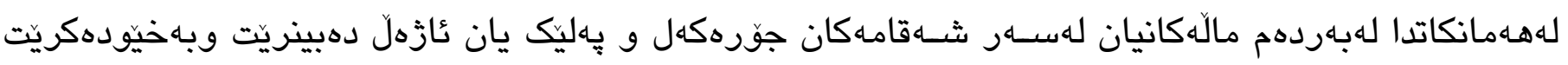

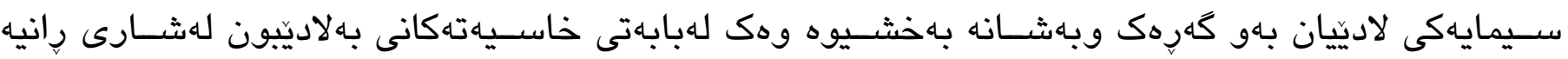

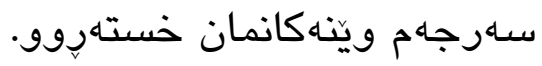

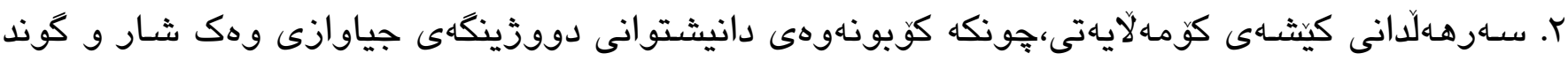

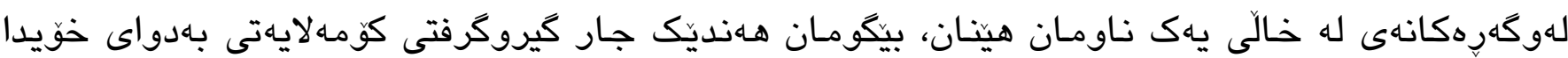

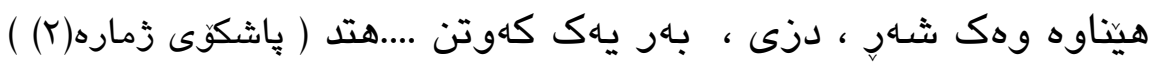

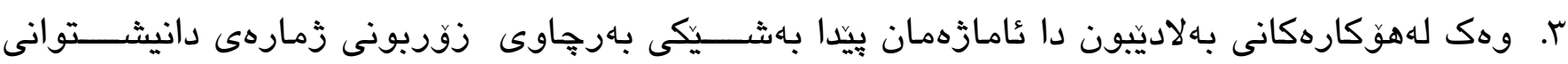

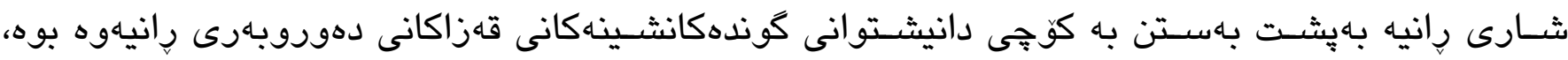

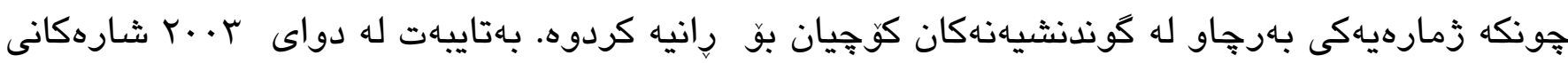

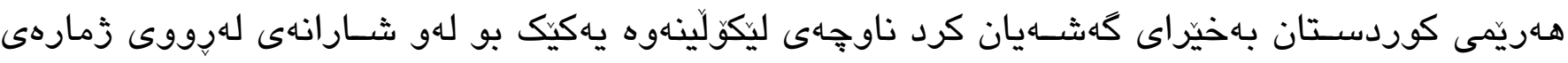

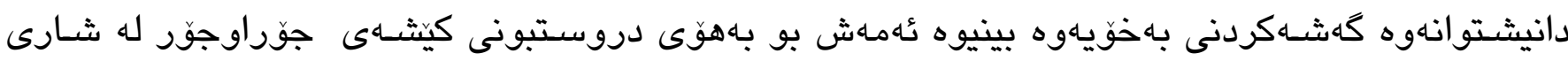

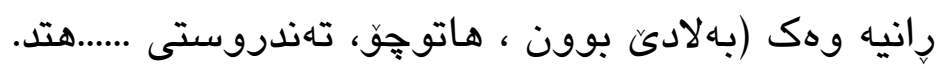

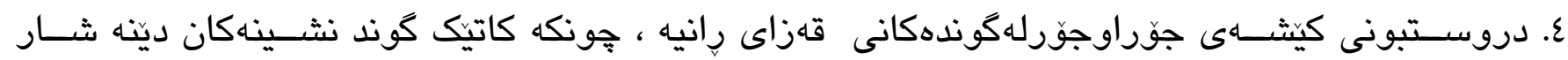

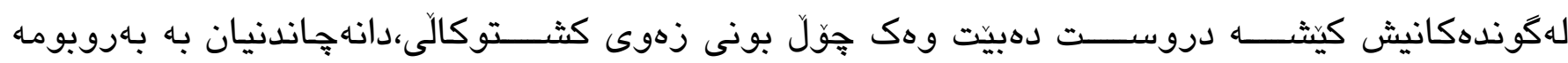

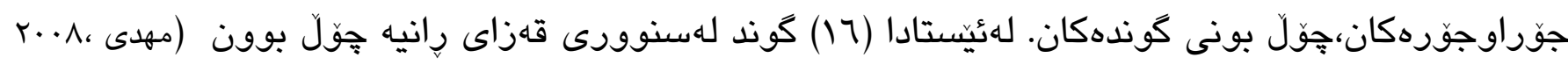

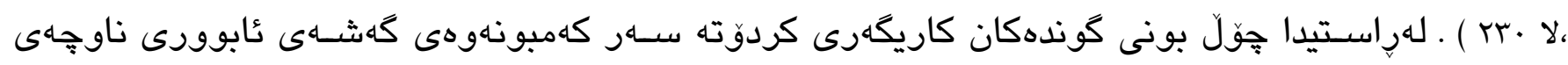
ليكوَ لَينهوه.

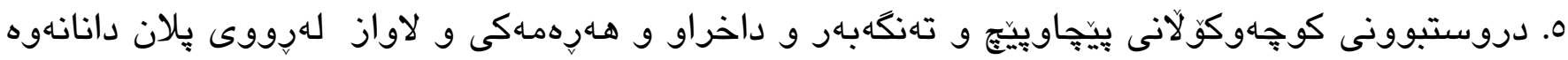

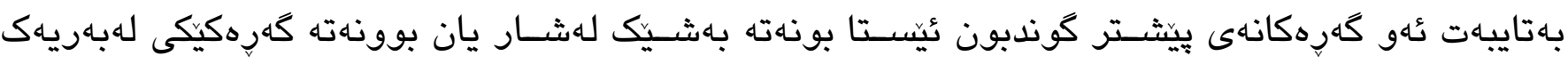

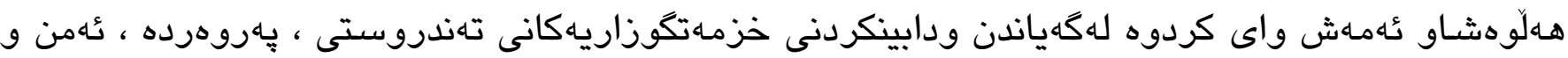

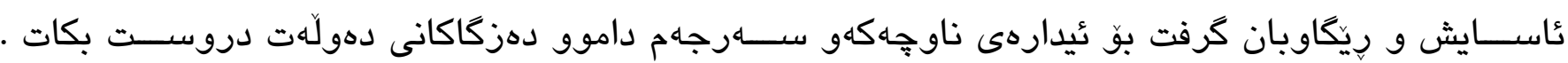

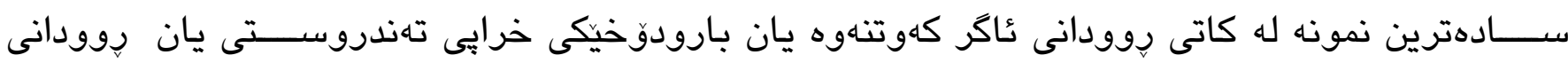

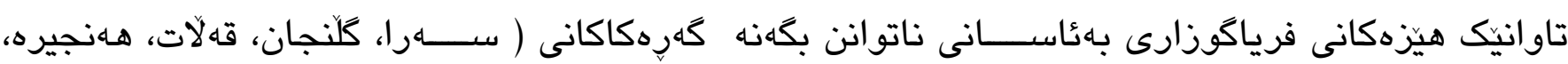

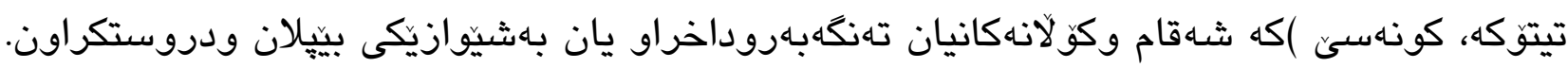




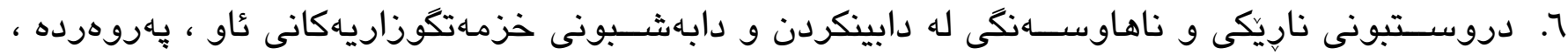

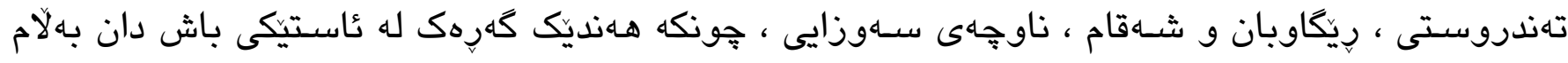

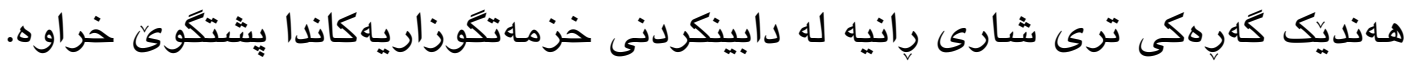

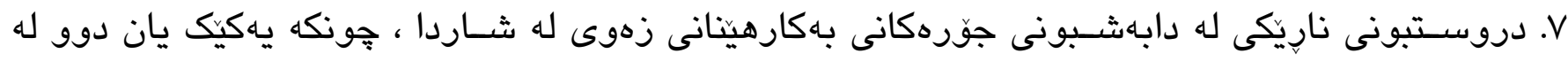

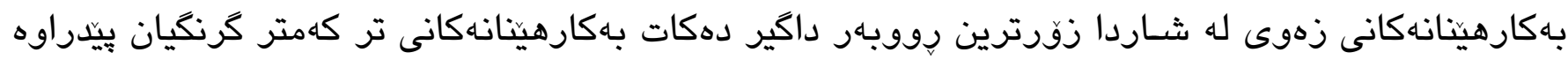

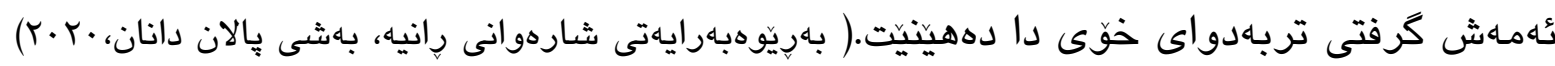

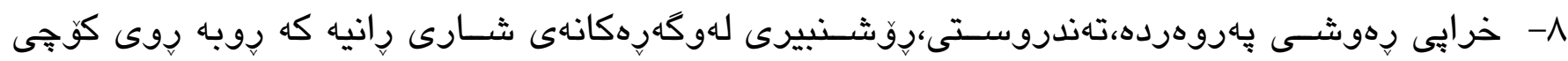

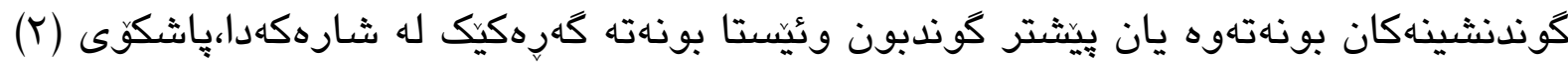

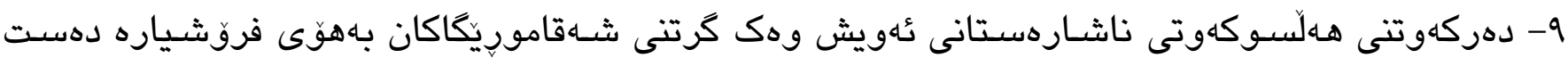

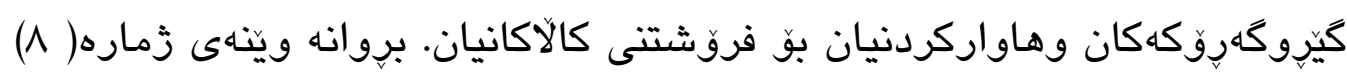

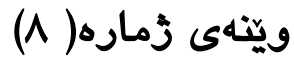
كرتنى شهاقامهكان لهلايهن فروشياره دهست كيّروكهِيَوكهكان

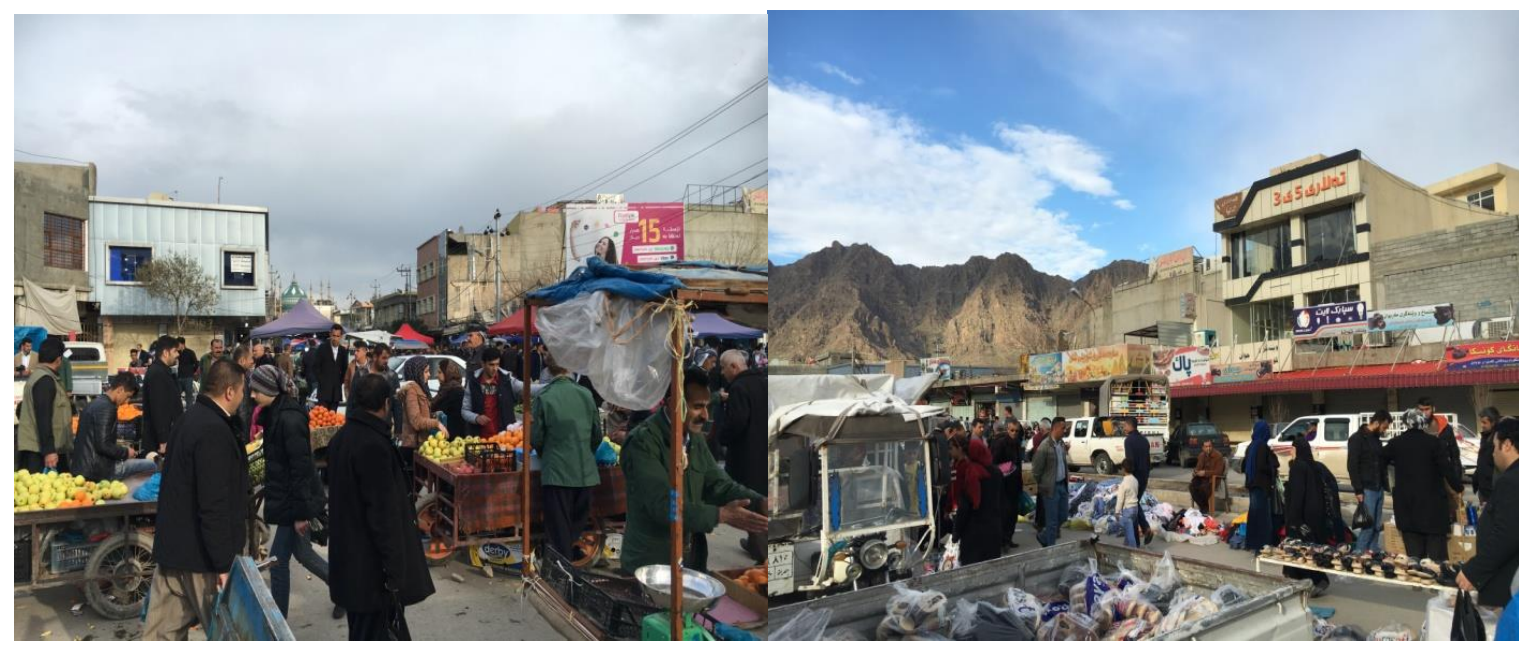

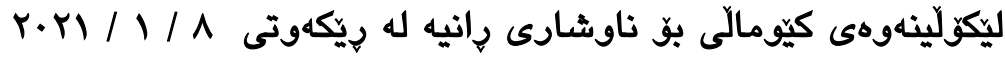

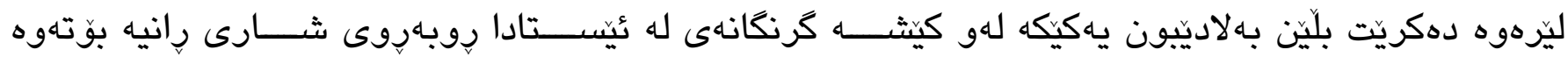

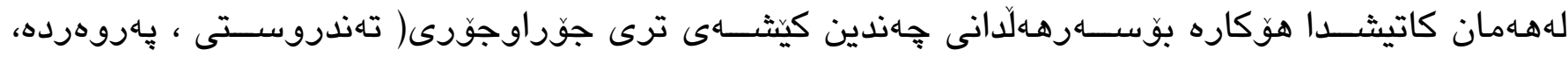

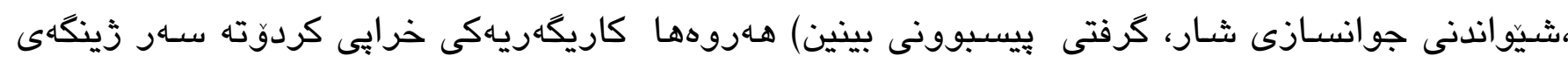

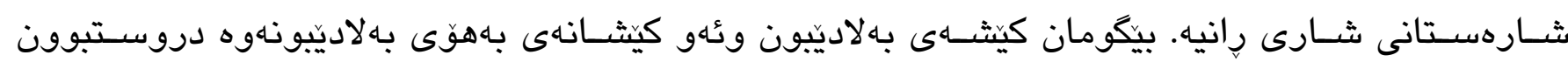

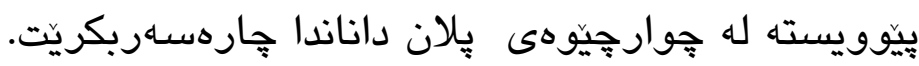

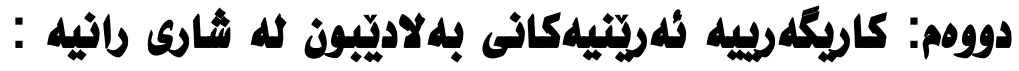

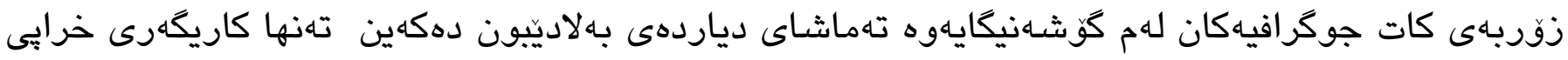

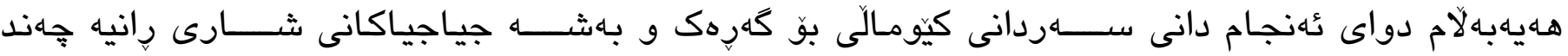

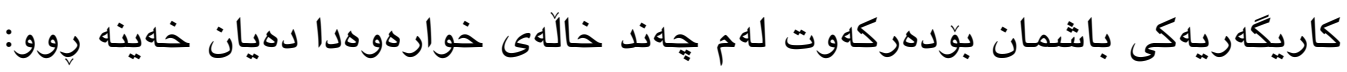




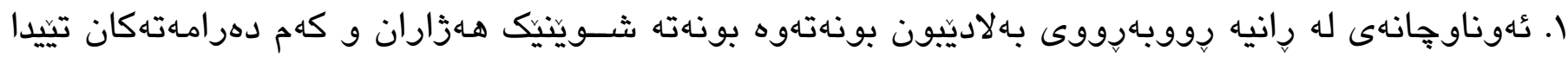

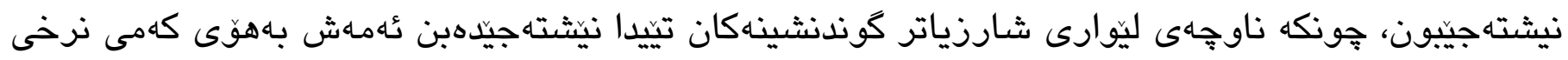

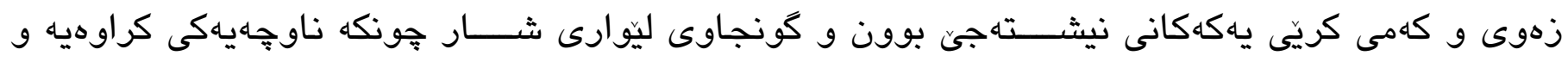

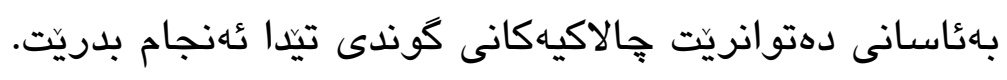

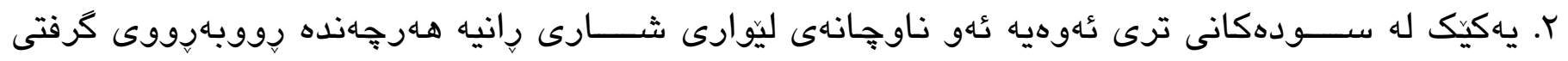

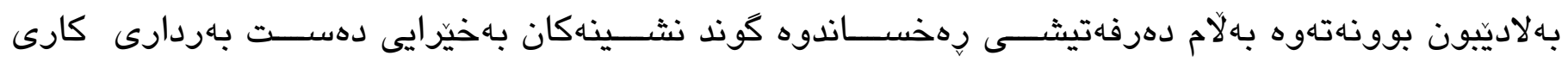

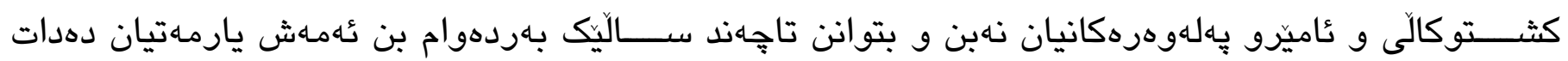

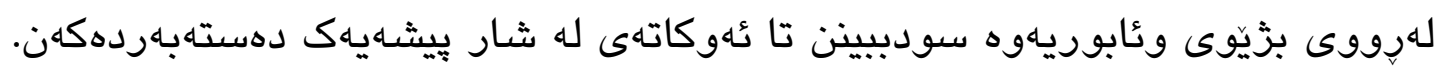

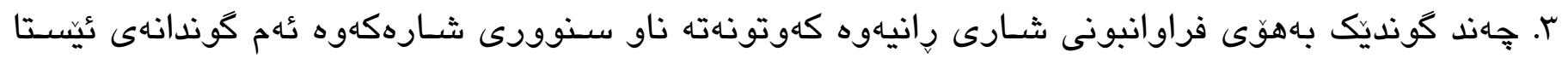

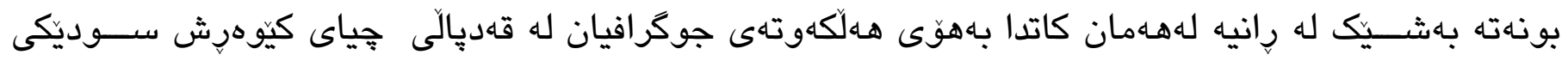

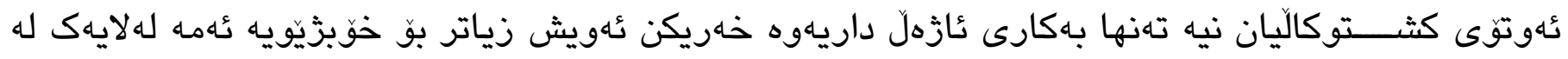

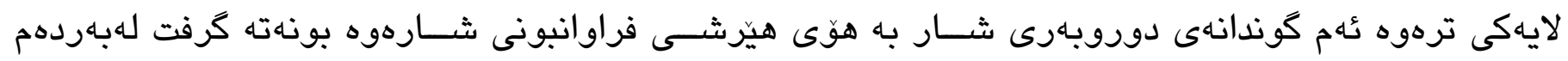

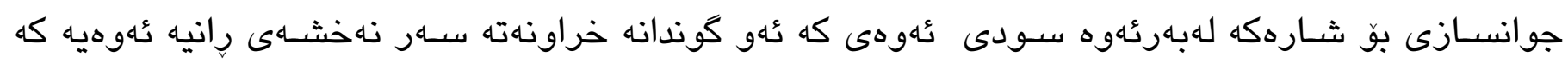

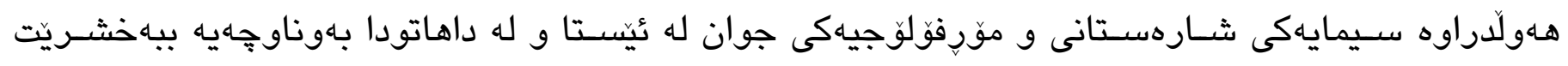

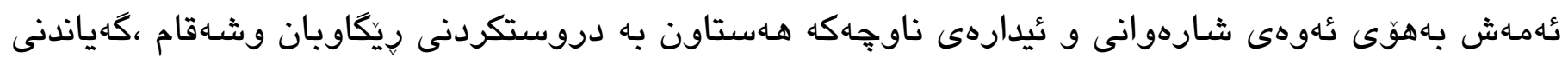

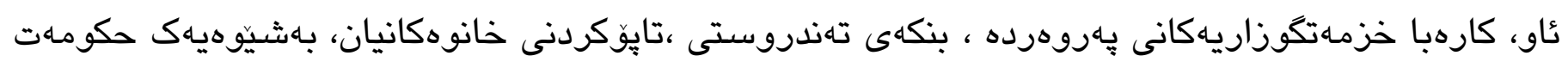

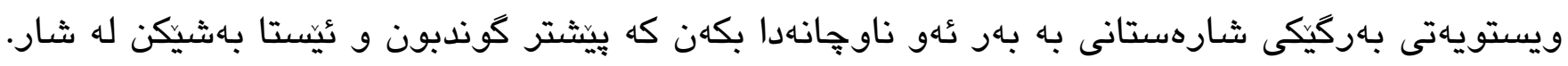

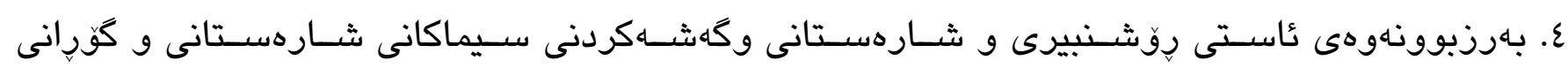

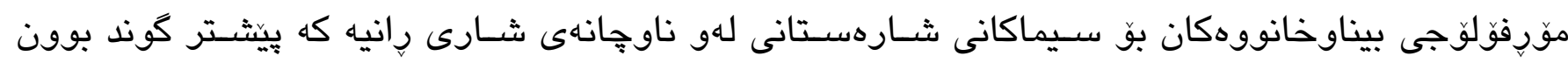

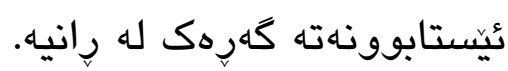

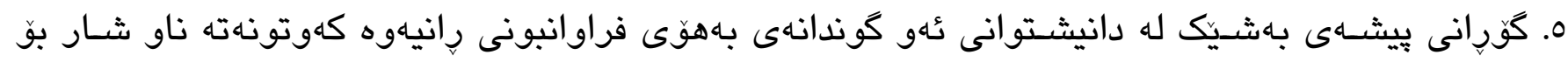

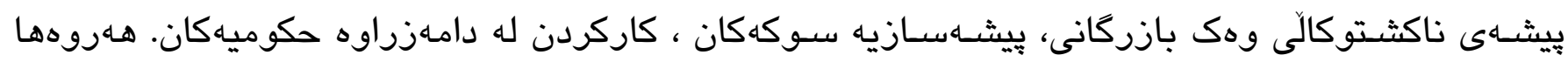

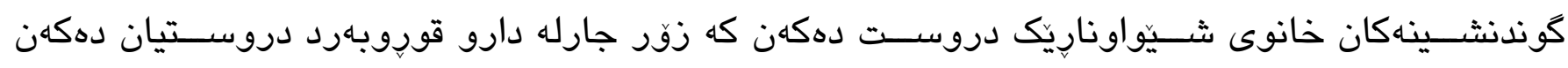

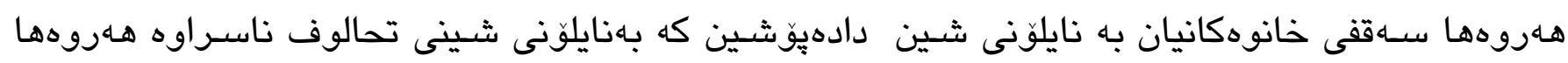

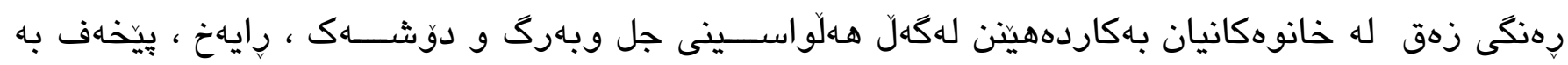

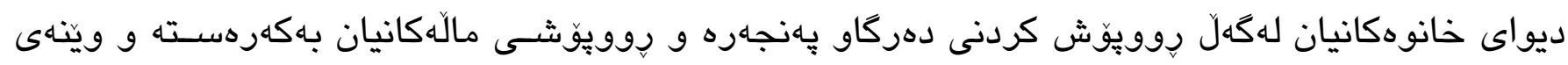

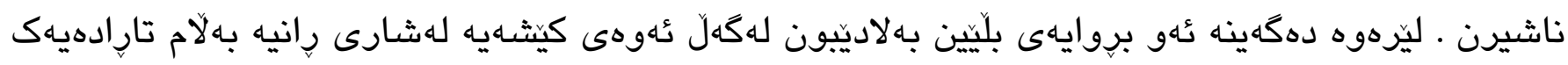

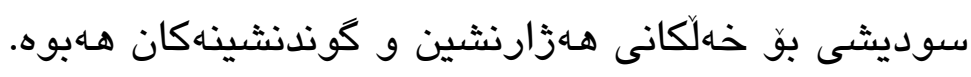

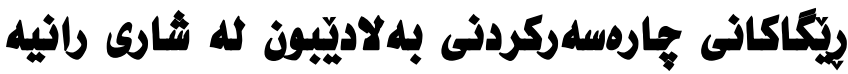

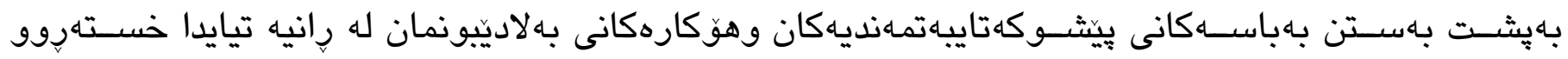

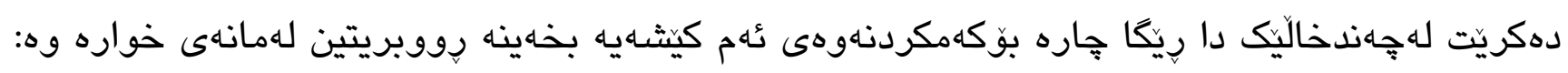

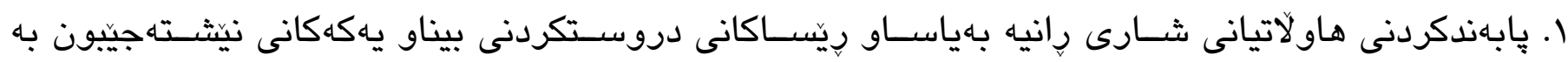

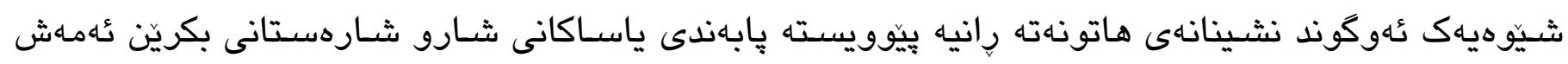

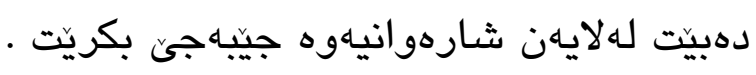




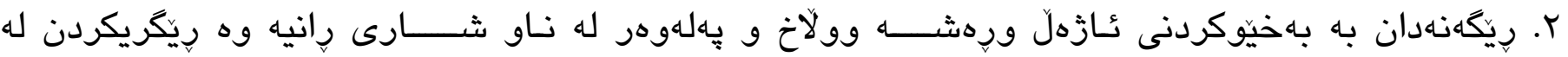

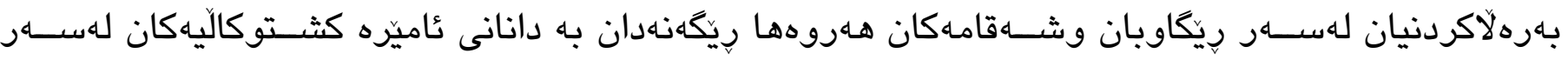

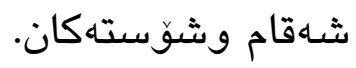

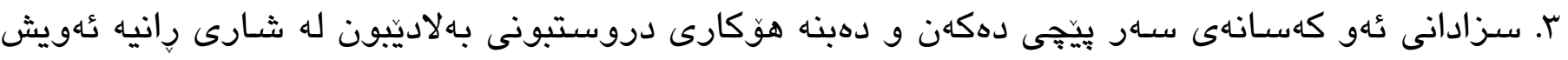

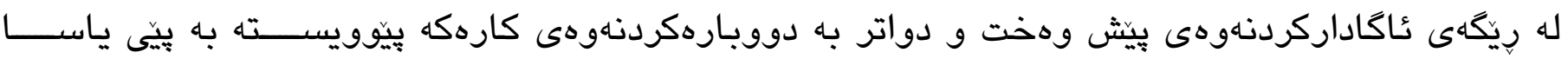

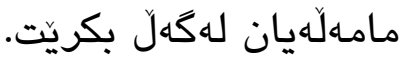

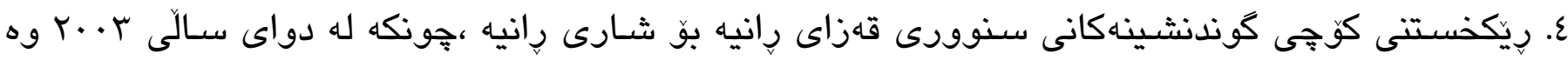

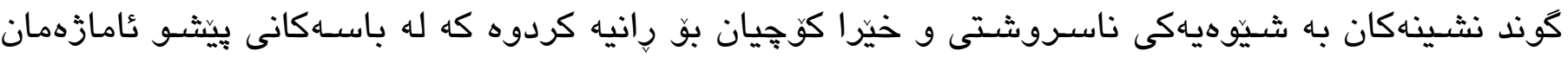

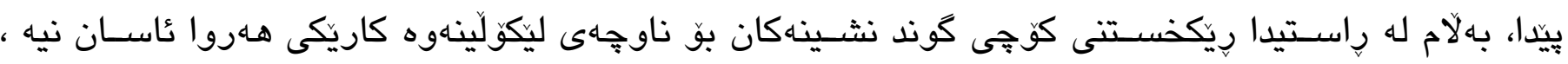

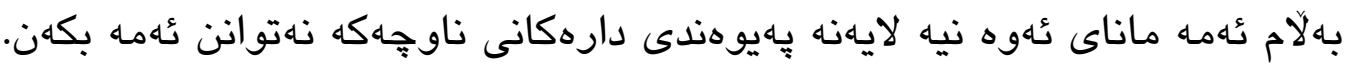

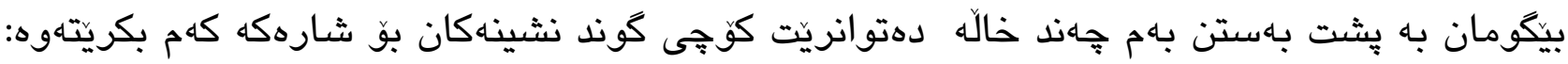

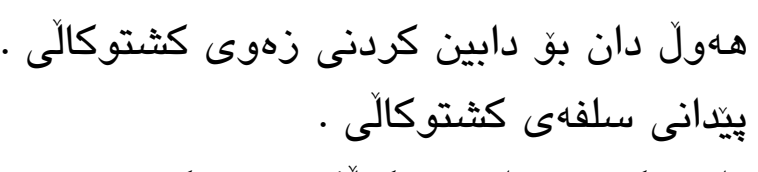

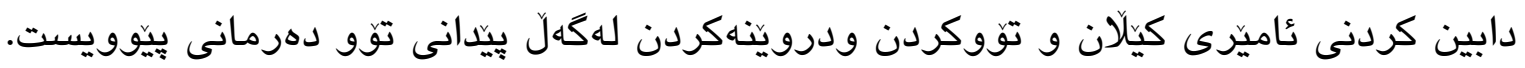

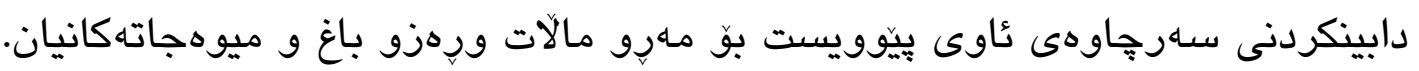

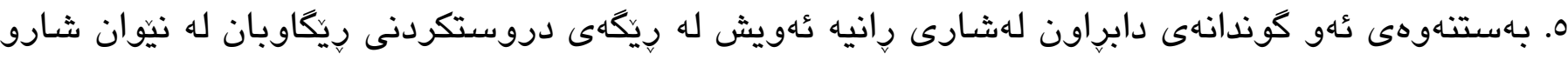

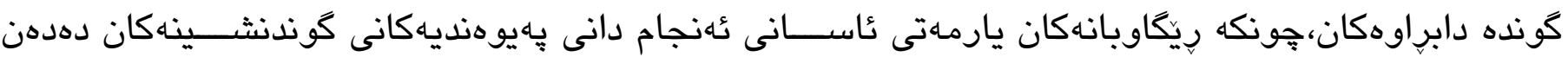

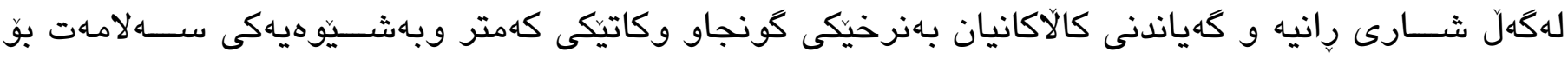

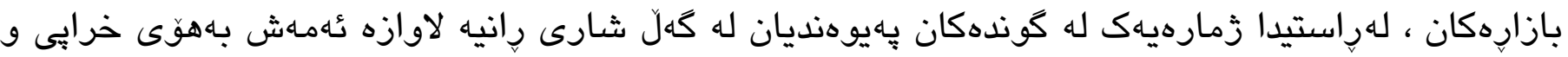

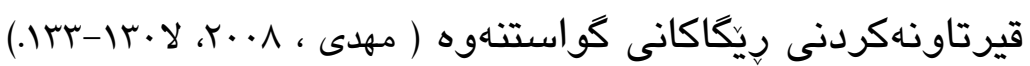

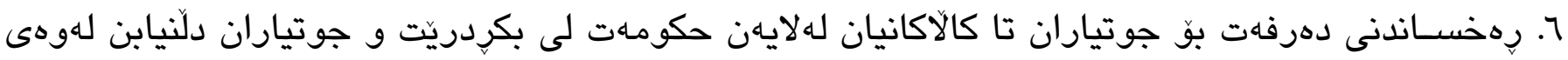

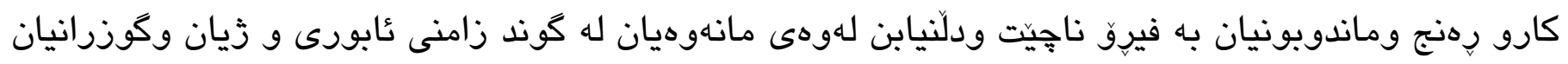

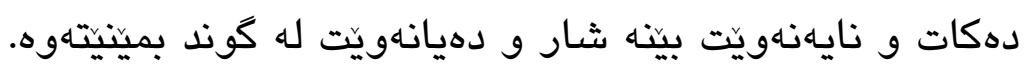

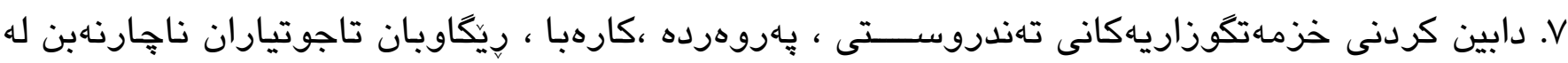

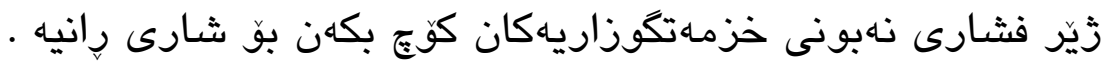

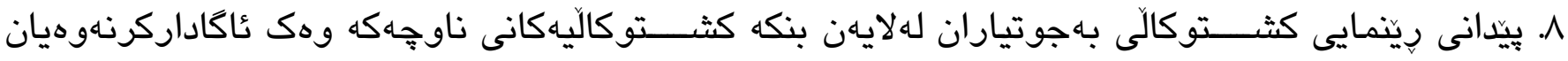

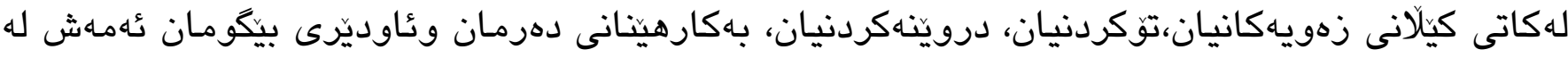

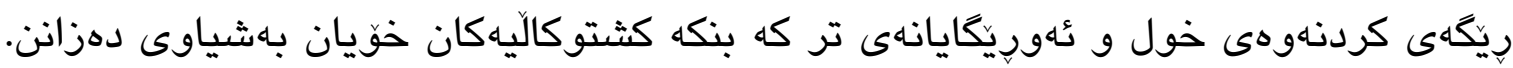

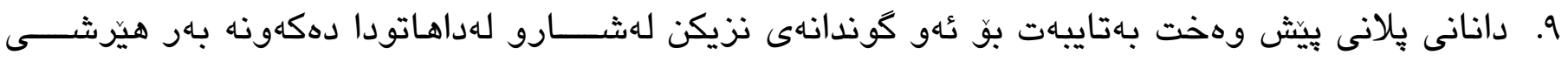

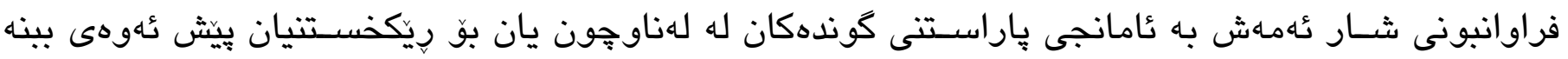

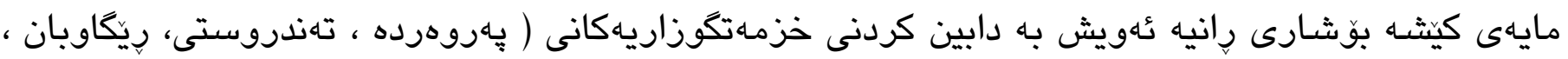

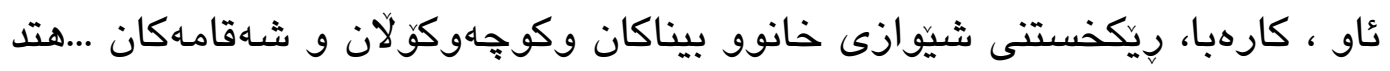

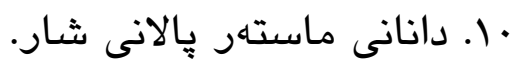

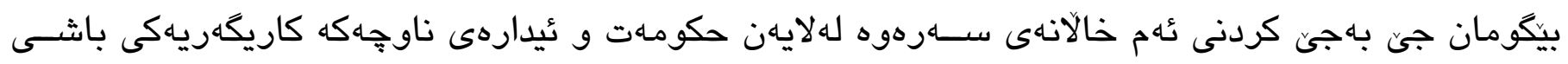

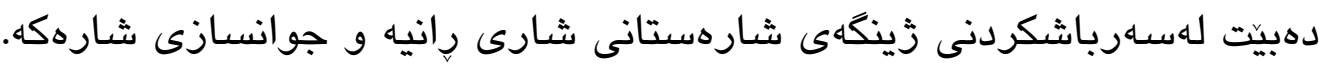




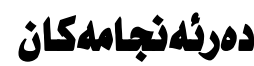

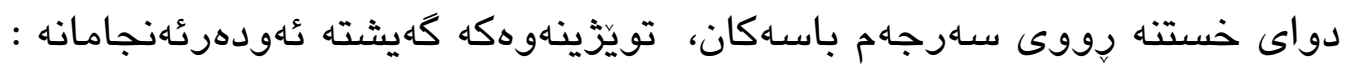

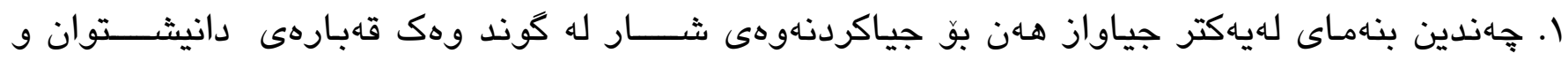

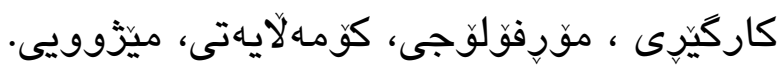

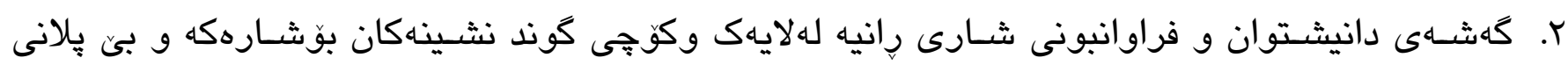

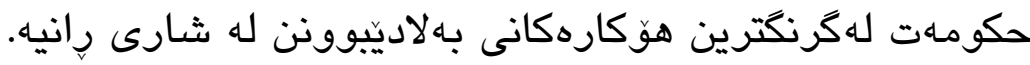

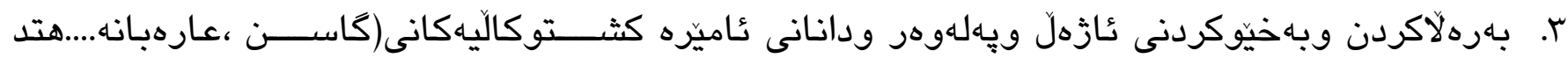

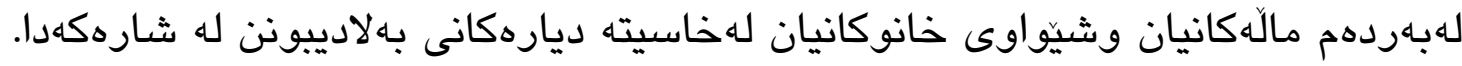

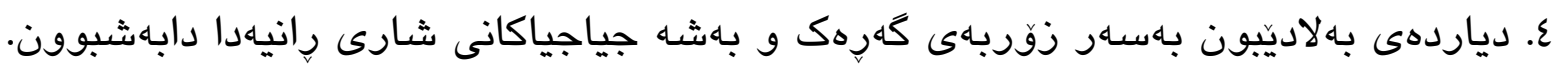

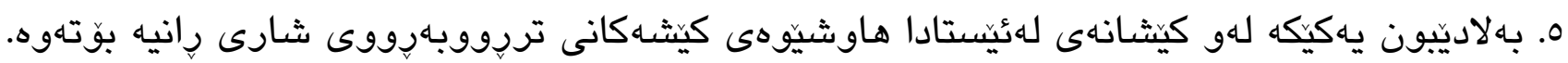

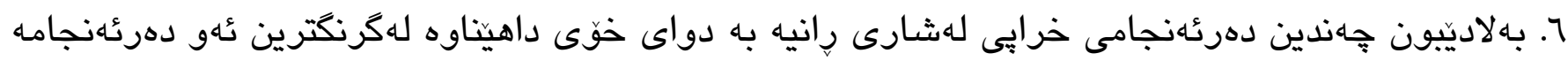

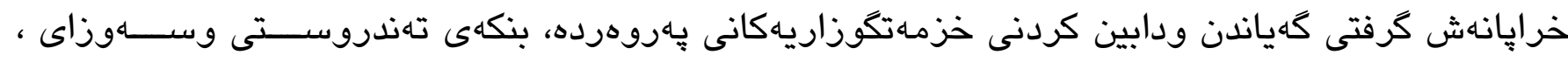

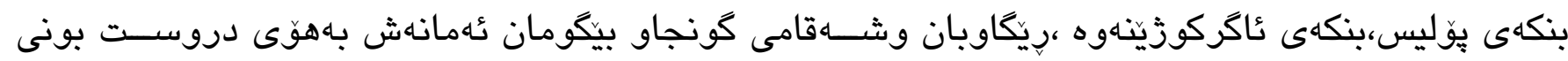

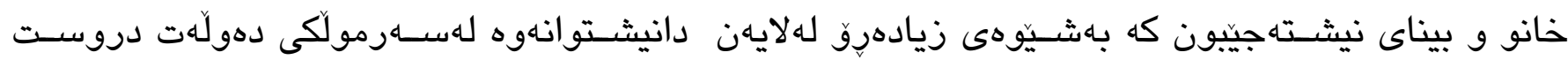

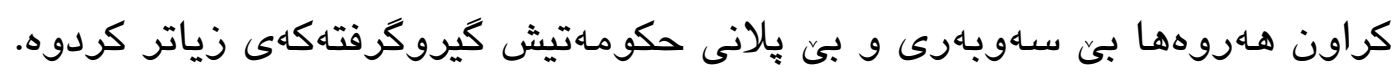

\section{كانئin}

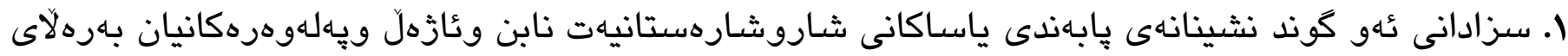

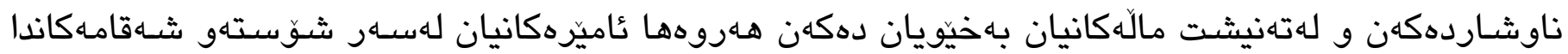

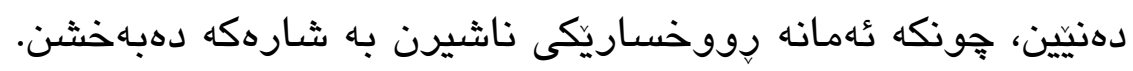

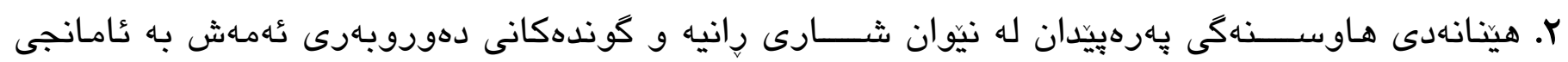

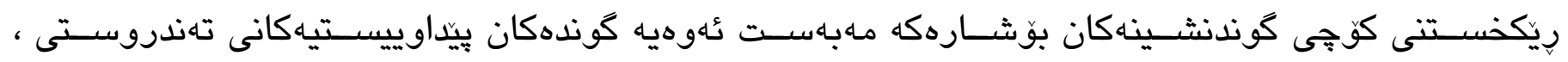

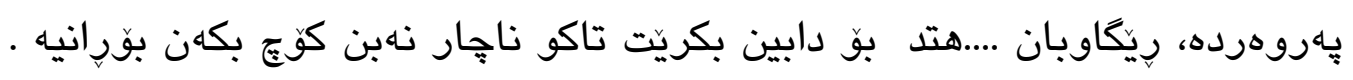

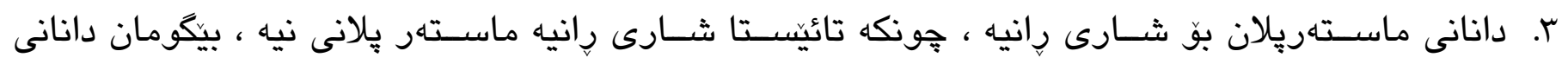

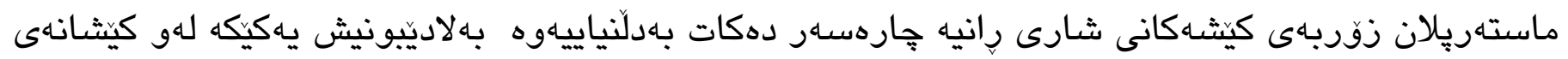

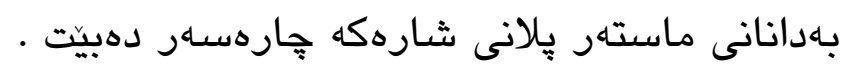

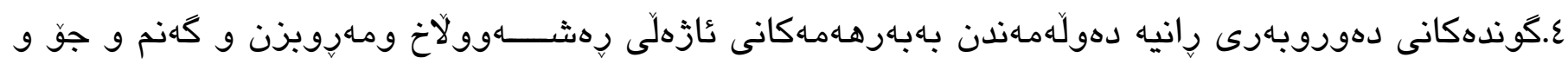

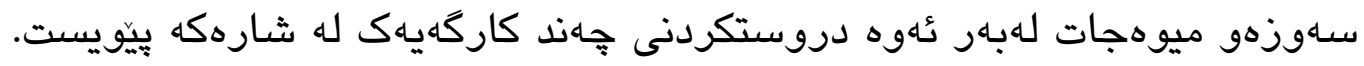




\title{
Geographical Analysis of Ruralization Phenomenon in Rania City and Impact on Their Urban Enviroment
}

\section{Bestun Ahmed Hussein}

Geography Department, College of Humanities, University of Raparin, Rania, Kurdistan Region, Iraq.

E-mail: bestoon.78@uor.edu.krd

\begin{abstract}
:
Ruralization of Urban areas is one of the most important topics of Urban Geography as it is one of the issues of urban areas and a major contributor to other urban issues; therefore, researchers need to look at this issue with caution. Ranya city has experienced this issue to a great extent mostly due to population growth and urban expansion. Ruralization has caused major issues such as infrastructure issues in terms of education, health, transportation and increased crime rates in different parts of the city.

This research addresses this issue and aims to investigate the causes and characteristics of ruralization in Ranya city. This effort will help the local government to look for solution to address this issue. This research has used descriptive and analytical methods.The research concludes that ruralization has caused some drastic consequences when it comes to providing and delivering different public and infrastructure services. The paper recommends to authorities that preparing a master plan for the city would be the ideal resolution for this issue and other issues in the city.
\end{abstract}

Keywords: Developing City, Ruralization City, City, Village. 


\section{س رجاومكاز}

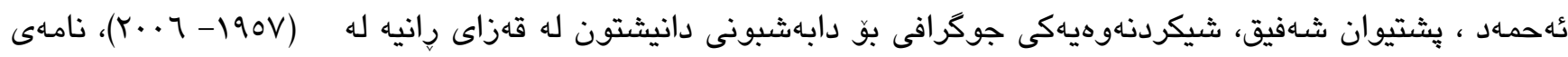

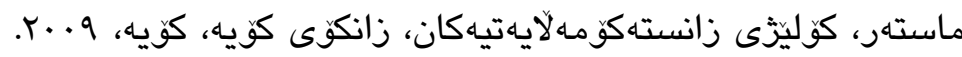

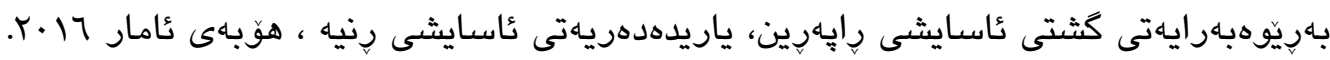

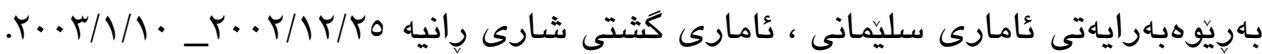
بهاريّوهبهرايهتى ثُامارى سليّمانى،ئامارى شارى رِانيه له

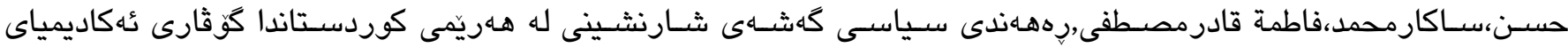

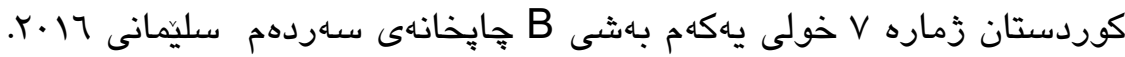

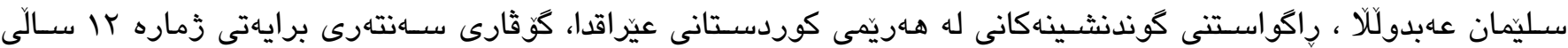
دووهم جايخانهى وهزارهتى پِروهرده ، هـوليّز ، 1999.

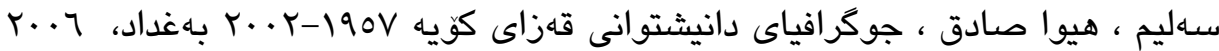

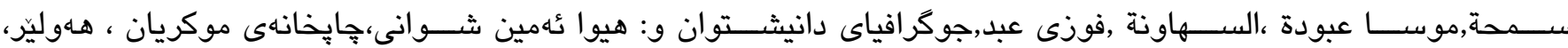
سال،9.9.9.

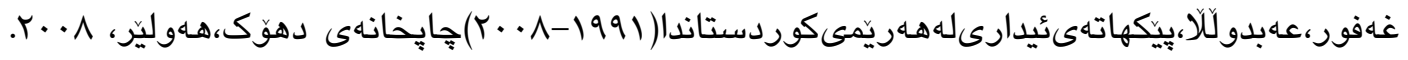

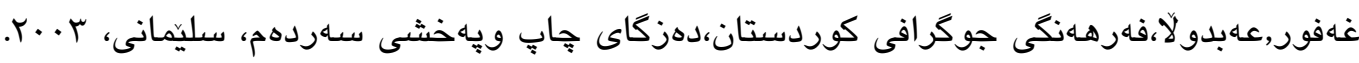

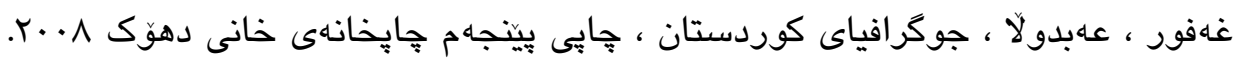

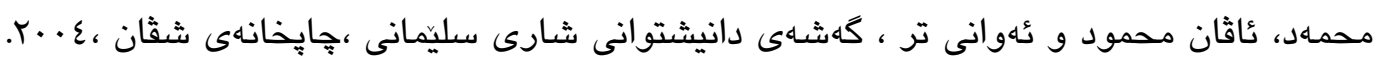

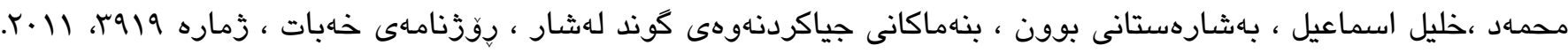

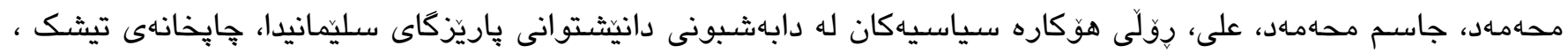
.$r \cdot \Lambda$

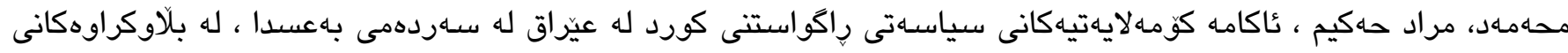

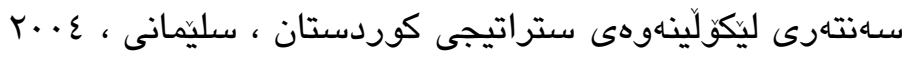

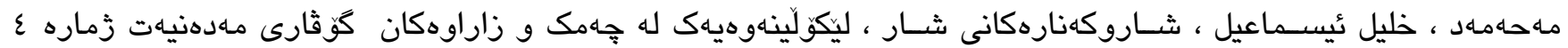
سالخى يهكه مجايخانهى داناز سليمانى 1999.

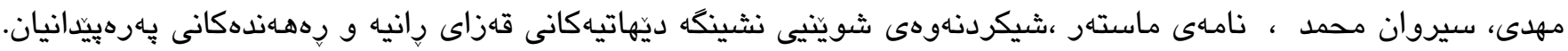

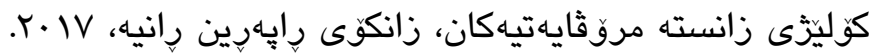

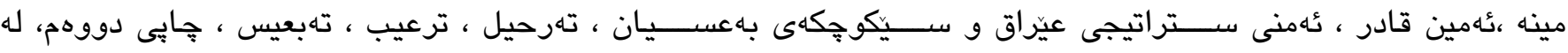
بلاوكراوهكانى سانتهرى ليكولينهوهى ستراتيجى كوردستان، سليَمانى ، 1999

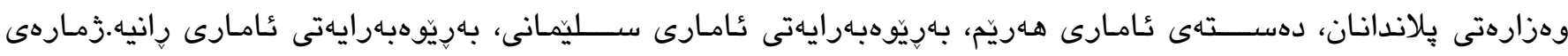

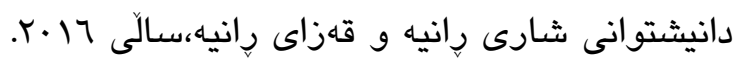

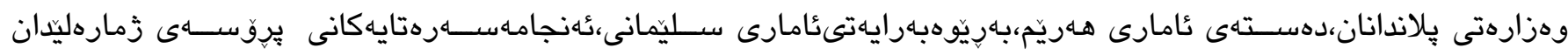

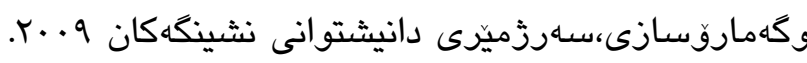

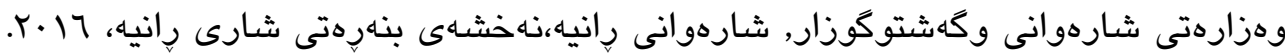




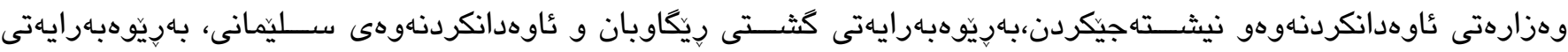

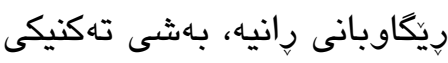

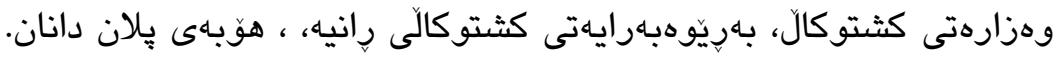

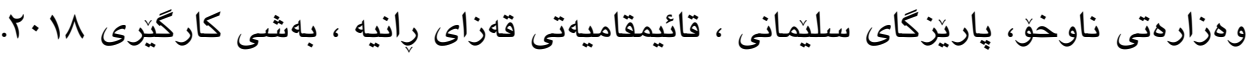

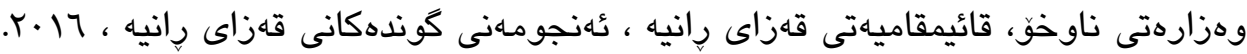

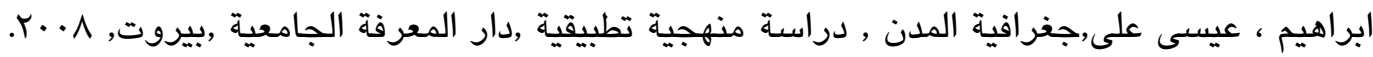

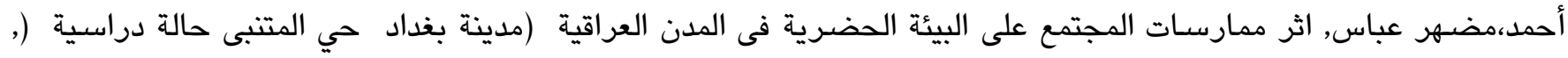

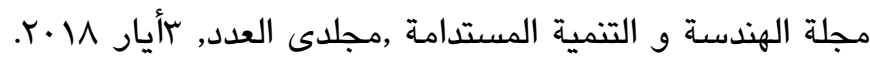

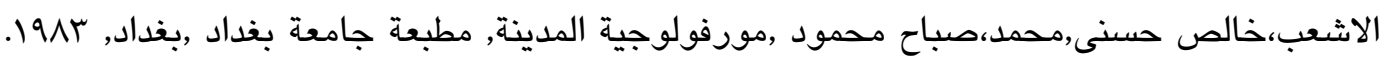
أل مدرس،سـاكار بهاءالدين عبداللة,التدهور الحضرى فى المدن (أسس و تطبيقات وسبل المعالجة ) دراسـة تطبيقية على مدينة

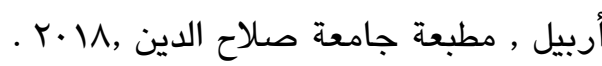
بعيرات ،ريم, أسباب و أثار مضاهر ضاهرة ترييف المدن و تمدن الريف(رأم الله,البيرة, بيتونيا ,بيتين) كحالة دراسية , رسالة

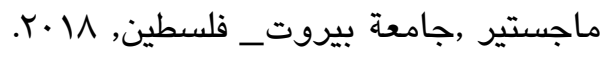
بومدين، دحام محمد، اندماج المهاجرين الريفيين فى الوسط الحضرى دراسـه ميدانيه بمدينه الجلفه، رسـاله ماجستير فى علم

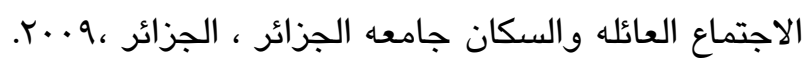

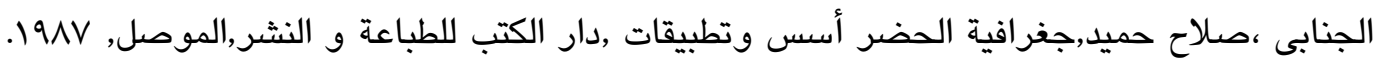

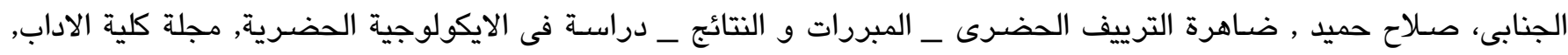
جامعة بغداد, , عدد 09 , بغداد, , ب.... الجواهر ، محمد سـالم سـعيد, النمو الحضـرى فى ســاحل خضـرموت بين الشـعر و الحلة اطروحة دكتوراة كلية الاداب جامعة

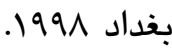

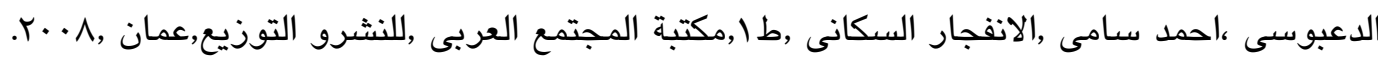
الشواورة ، على سالم ، جغرافية المدن، دار المسيرة للنشر والتوزيع و الطباعة ، عمان، ب. ب. r.

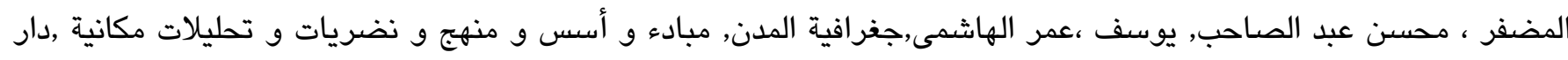

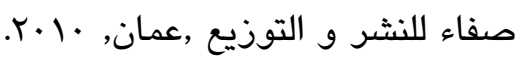

الهيتى،صبرى فارس،حسن،صالح فليح ،جغرافيةم المدن،دار الكتب للطباعةو النشر،الموصل ، 1910. الهيتى ، صــبرى فارس,خليل اســماعيل محمد ,جغرافية الاســيطان الريفى , وزارة التعليم العالى والبحث العلمى جامعة بغداد, مطبعة التعليم العالى ,جامعة الموصل , الموصل, 1919 حسين ،بيان على ، التحليل الجغرافى لإتجاهات النمو الحضرى في محافظة السليمانية، اطروحة دكتوراه، كلية العلوم الإنسانية،

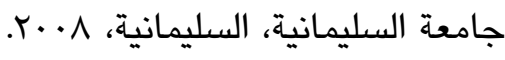
حسين ،عبدالرزاق عباس ، نثأة مدن العراق وتطورها، مطبعة الارشاد، بغداد، 19VV.

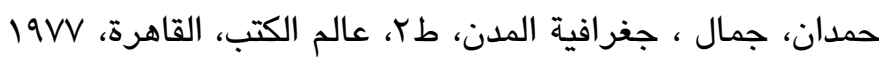

خطاب ، عادل عبداللة ,جغرافية المدن , مطبعة التعليم العالى ,الموصل, ـأ.199. رونج، نيس .ه., علم السكان , ترجمة السيد محمد غلاب , دار مصر للطباعة ,القاهرة , 197V.

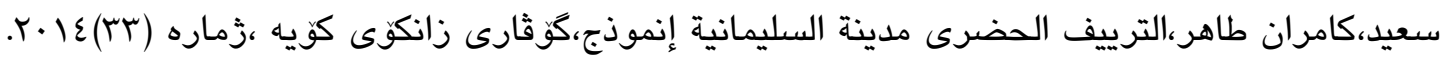
عطوى ،عبداللة ,جغرافية المدن, الجزء الاول, دار النهضة العربية ,بيروت ,لبنان, ال... 
عطال ، مسـعود , النمو الحضـرى و علاقته لمشـكلة البيئية الحضـرية( دراسـة ميدانية بحى طريق حملة بمدينة باتنة , رسـالة

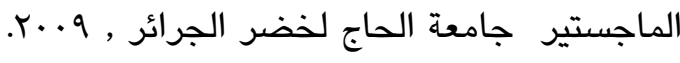
على ، حسـين اسـماعيل, النمو الحضـرى فى مدينة السـليمانية دراسـة فى علم الاجتماع الحضـرى رسـالة الماجستير كلية العلوم

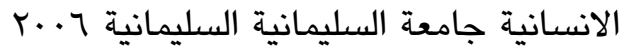

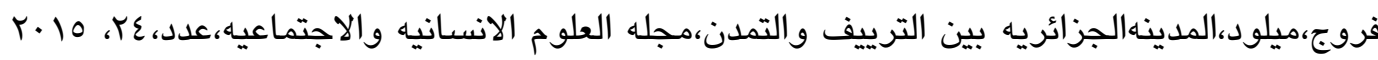
محمد،خليل اسماعيل،السكان والمسألةالسكانية في كردستان العراق،جامعة صلاح الدين،اربيل، Y. ·.

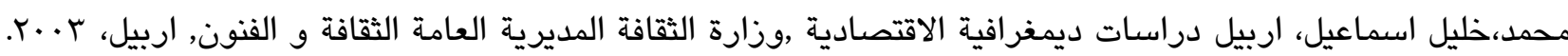

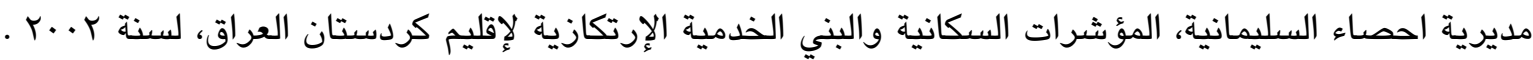

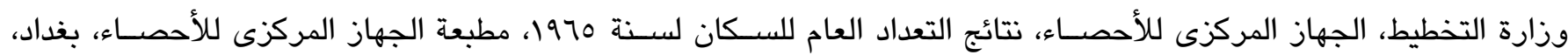

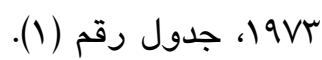
وزارة التخطيط، الجهاز المركزى للأحصاء، نتائج تعداد العام السكان محافظة السليمانية، لسنة 19VV، المطبعة الجهاز المركزى

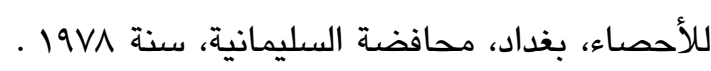

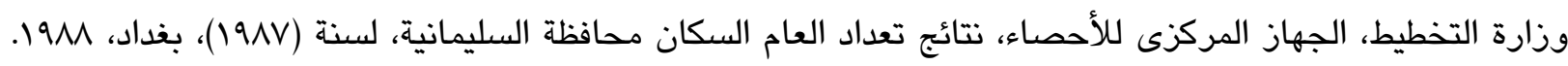
وزارة الداخلية، مديرية النفوس العامة، المجموعة الإحصـائية لتسـجيل 190V، لوائى السـليمانية وكركوك، مطبعة العانى، بغداد،

جدول رقم (^) ، وجدول رقم (ع).

وزارة تخطيط، هية التخطيط، الاقليمى، معايير تحديد المناطق الحضرية ق والريفية فى العراق دراسة رقم ب.r. Shorsh, M. Resool, Destruction of Anationopcit , printe in (USA) 1990. John I Clarkk, Population Geography, $2^{\text {nd }}$ Edition, Pergaman Press .Oxford, 1972, P146 paul jones the risee of the rural villag in the city and village cities in the pacific region 2011. MagdalenaWilkosz-Mamcarczyk 1,*, Barbara Olczak 2 and Barbara Prus Urban Features in Rural LandscapeA Case Study of the Municipality of S kawina 2020. 


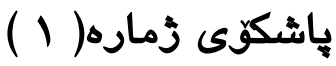

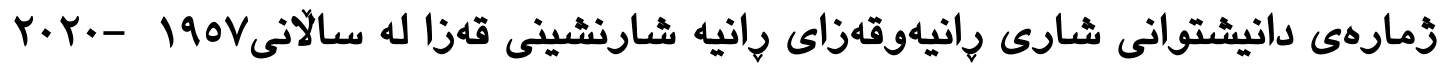

\begin{tabular}{|c|c|c|c|}
\hline ز. دانيشتوانى شـارنشينى قهزا & ز. دانيشتوانى قهزاى رانيه & ز. دانيشتوانى شارى رِانيه & 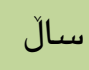 \\
\hline r910 & $m .9 V$ & rา71 & $190 \mathrm{~V}$ \\
\hline $71 \varepsilon \varepsilon$ & $\varepsilon 79 \% \mathrm{~V}$ & rosA & 1970 \\
\hline $110 \cdot 0$ & 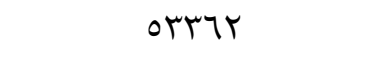 & $\wedge \vee \wedge T$ & $19 V$ \\
\hline$\varepsilon 99 \wedge 7$ & $V V \cdot 07$ & TVW. & $191 \mathrm{~V}$ \\
\hline IFTVKA & ITYETE & TITYV & $r \cdots r$ \\
\hline$I V \cdot \cdots T$ & 197001 & $V \varepsilon \cdot 9 r$ & $r \cdot . q$ \\
\hline rIrEoq & $r \varepsilon \cdots \wedge$ & $910 \varepsilon V$ & $r \cdot r \cdot$ \\
\hline
\end{tabular}

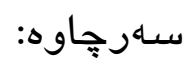

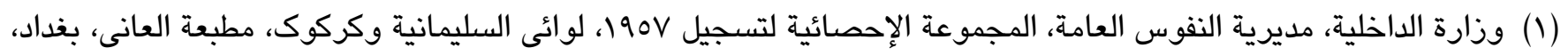

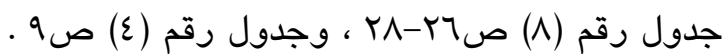

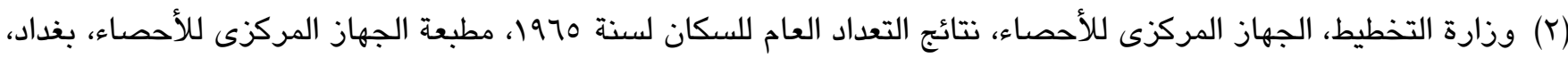

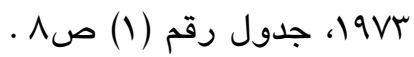

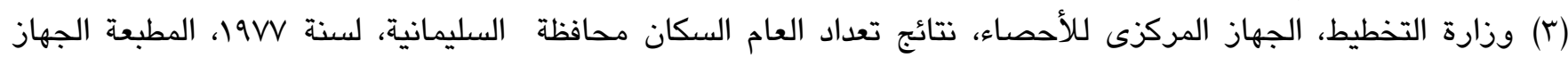

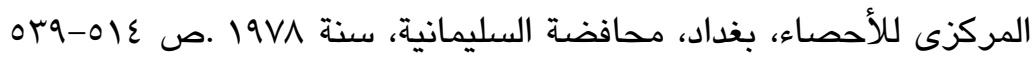
(ع) وزارة التخطيط، الجهاز المركزى للأحصاء، نتائج تعداد العام السكان محافظة السليمانية، لسنة (19AV)، بغداد، 1911 (191) ,

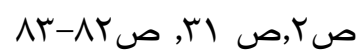

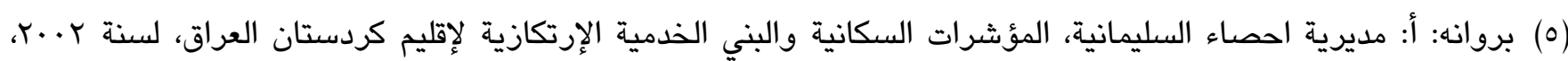

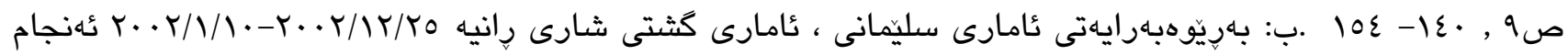
دراوه لاזنا.

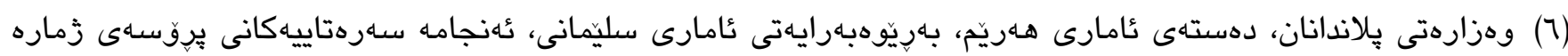

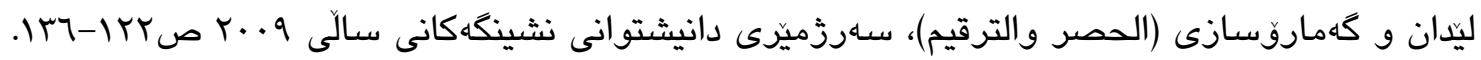

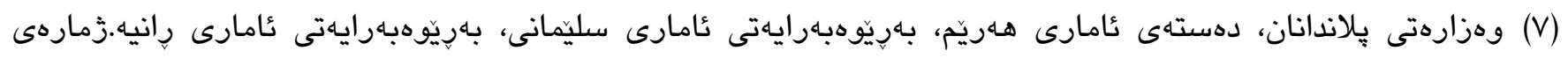

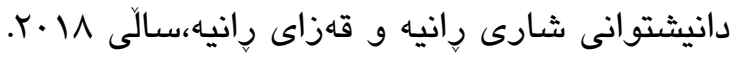




\section{(Y) (باشكوى زُماره \\ فوزيمى بإيرسى توماره}

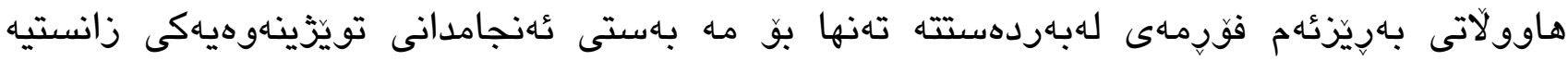

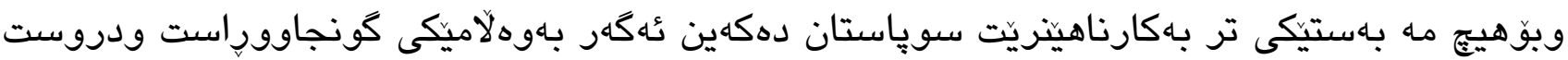

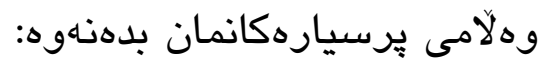

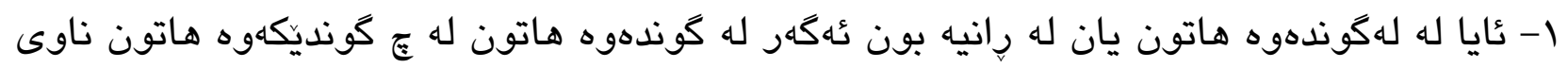
كوندهكهت بنوسه

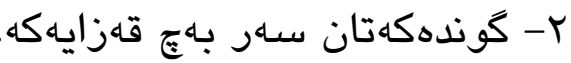

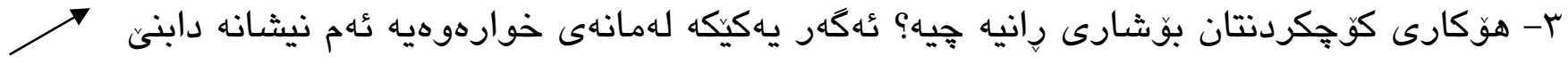

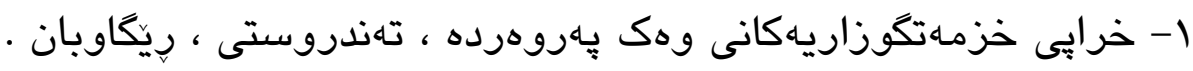

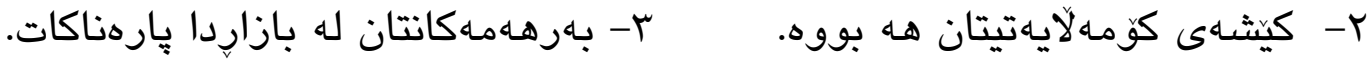

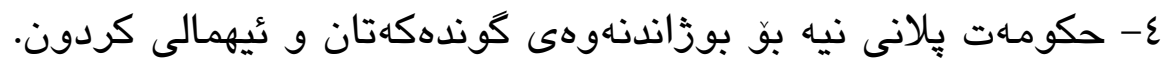

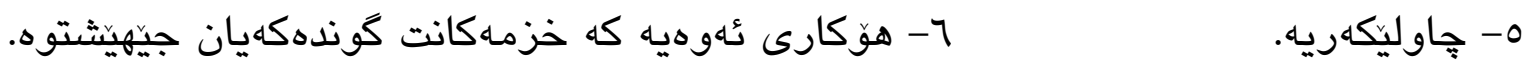

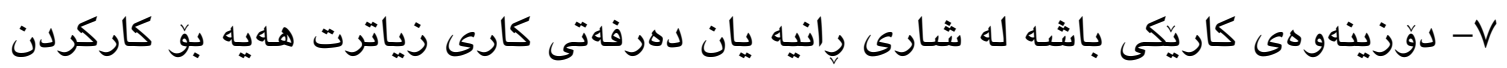

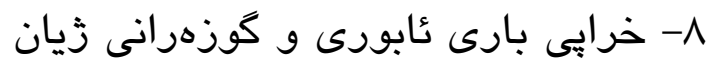

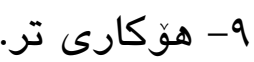

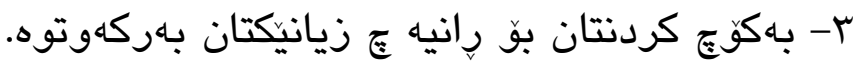

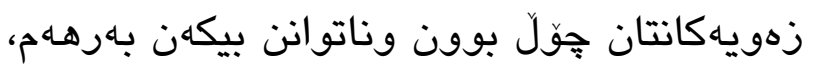

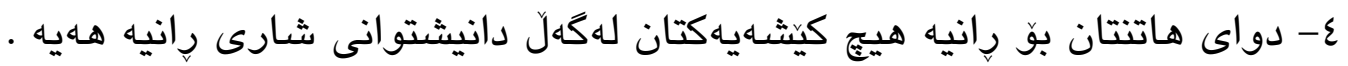

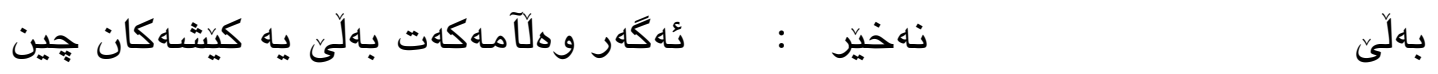

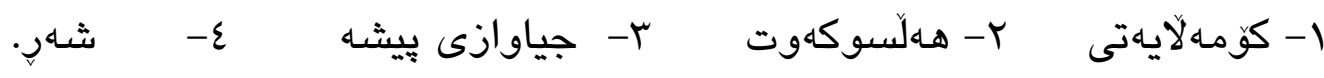
هيتر.

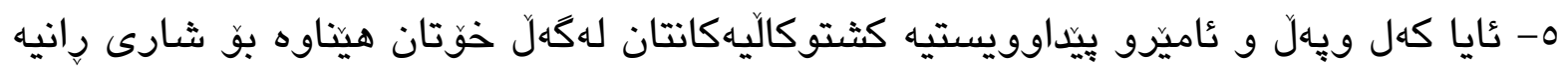

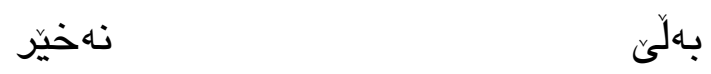

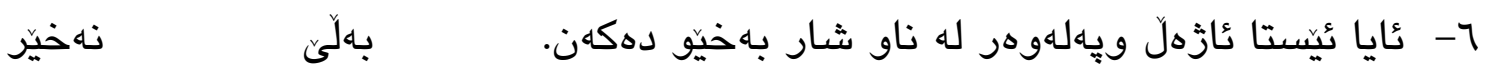

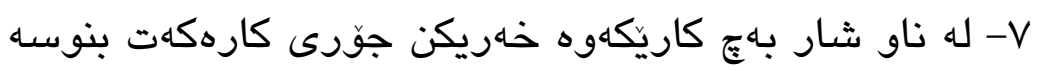

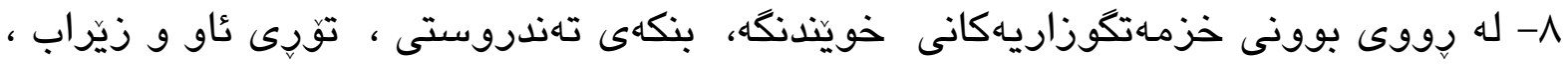

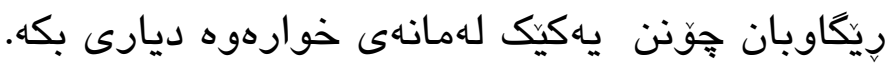

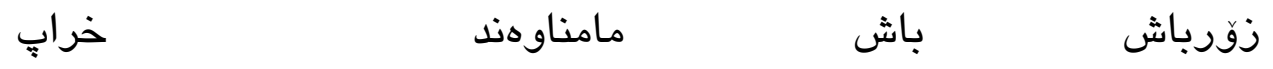
سوياس بو هاوكاريت تويَزْهر 